\title{
Last interglacial (MIS 5e) sea surface hydrographic conditions in coastal southern California based on dinoflagellate cysts
}

\author{
by \\ Jin-Si R.J. Over \\ B.Sc., University of North Carolina at Wilmington (Honors), 2016
}

\begin{abstract}
A Thesis Submitted in Partial Fulfillment of the Requirements for the degree of MASTER OF SCIENCE

In the School of Earth and Ocean Sciences
\end{abstract}

(C) Jin-Si R.J. Over, 2019

University of Victoria

All rights reserved. This thesis may not be reproduced in whole or in part, by photocopy or other means, without the permission of the author. 


\title{
Last interglacial (MIS 5e) sea surface hydrographic conditions in coastal southern California based on dinoflagellate cysts
}

\author{
by \\ Jin-Si R.J. Over \\ B.Sc., University of North Carolina at Wilmington (Honors), 2016
}

\section{Supervisory Committee}

Dr. Vera Pospelova, Supervisor

School of Earth and Ocean Sciences

Dr. Jon Husson, Departmental Member

School of Earth and Ocean Sciences

Dr. Richard Hebda, Departmental Member

School of Earth and Ocean Sciences 


\begin{abstract}
The first high resolution record of dinoflagellate cysts $\sim 110-155 \mathrm{kyr}$ over Termination II and the last interglacial in the Santa Barbara Basin, California from ODP Hole 893A details a complex paleoceanographic history. Changes in cyst abundances, concentrations, diversity, and assemblages reflect climatic and ocean circulation changes, and are successfully used to make quantitative reconstructions of past sea surface temperatures and annual primary productivity with the modern analogue technique based on a dinoflagellate cyst database from the northeast Pacific. The dominance of heterotrophic dinoflagellate cyst taxa Brigantedinium spp. throughout most of the section indicates coastal upwelling is an important influence on the basin. Based on the dinoflagellate cyst assemblages, five cyst zones are identified and approximately correspond to the marine isotope stage boundaries and their associated changes in sea surface temperatures and sea level. Cooler intervals, MIS 6 and MIS 5d, are characterized by cold-water indicator species Selenopemphix undulata whereas thermophyllic taxon Spiniferites mirabilis characterizes MIS 5e. In contrast to other studies in the Pacific, the data shows a one to two-thousand-year cooling event $\sim 129 \mathrm{kyr}$ that correlates to the Termination II sea level still-stand of the two-step deglaciation. A significant increase in cyst concentrations of heterotrophic and autotrophic taxa in the latest MIS 5e implies enhanced primary productivity as a result of increased seasonal upwelling and the warm, nutrient rich waters entering the basin after sea level stabilizes near modern levels. The hydrological evolution and cyst signal of the last interglacial is similar to the development of the Holocene in the Santa Barbara Basin, but the sustained presence of Spiniferites mirabilis across MIS 5e indicates sea surface temperatures were higher than modern conditions. The quantitative reconstructions appear to be less reliable, and show wide sea surface temperature changes across MIS 6 to $5 \mathrm{~d}\left(\sim 6.2-10.7^{\circ} \mathrm{C}\right.$ in February; $12.6-20.3^{\circ} \mathrm{C}$ in August) similar to modern ranges, while annual primary productivity was confined to a higher narrower range $\left(\sim 456-586 \mathrm{~g} \mathrm{C} \mathrm{m}^{-2} \mathrm{yr}^{-1}\right)$.
\end{abstract}




\section{Table of Contents}

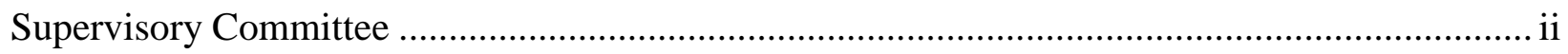

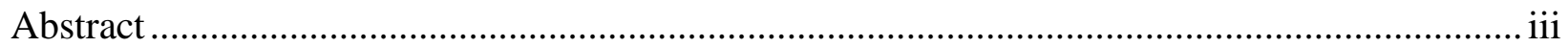

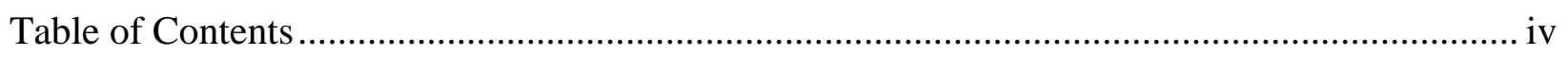

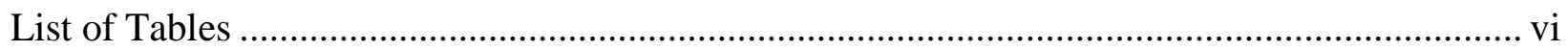

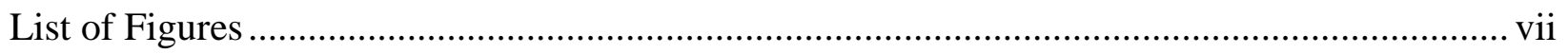

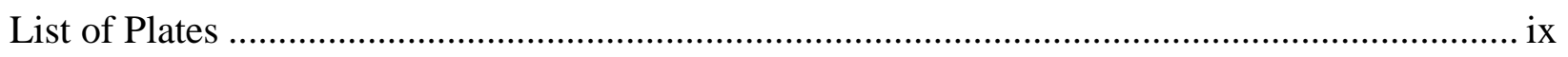

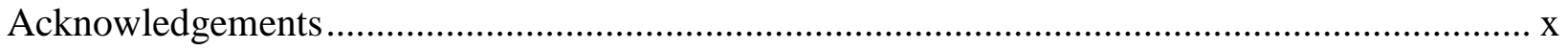

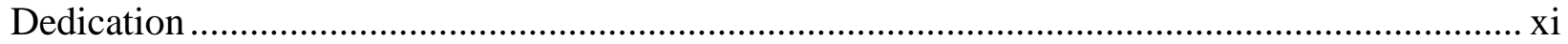

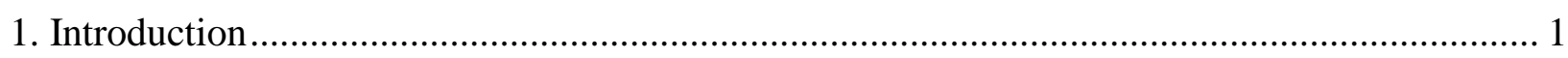

1.1 Marine Isotope Stage 5e and the Pacific Northwest ................................................... 1

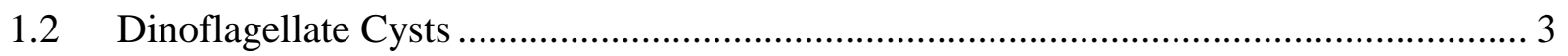

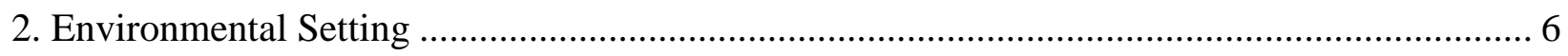

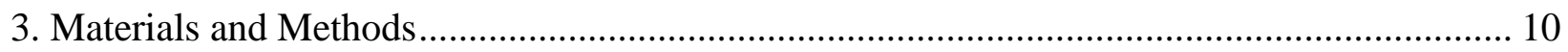

3.1 Palynological Sample Preparation and Microscopy ................................................. 10

3.2 Statistical Analyses and Quantitative Techniques ....................................................... 16

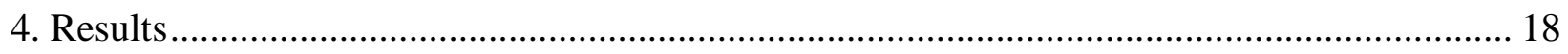

4.1 Palynomorph Total Concentrations, Abundances, and Ratios...................................... 18

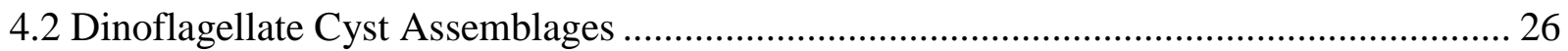

4.2.1 Zone D1 (Samples from 155.0 - 137.5 kyr. Transitional period from 137.2 - 136.1

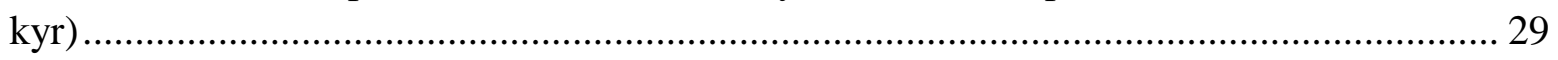

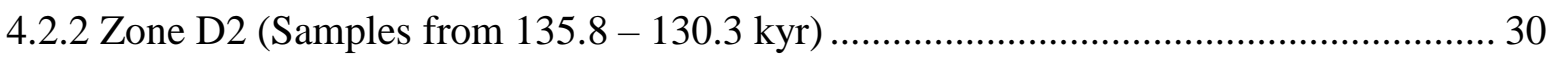

4.2.3 Zone D3 (Samples from 130.2 - 128.8 kyr) ..................................................... 30

4.2.4 Zone D4: Subzone 4a (Samples from 128.6 - 122.9 kyr), Subzone 4b (Samples from 122.8 - 119.8 kyr. Transitional period from 119.6 - $118.1 \mathrm{kyr})$.................................... 31

4.2.5 Zone D5 (Samples from 117.8 - 109.2 kyr) .................................................... 32

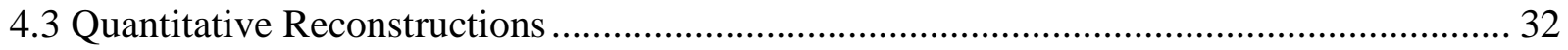

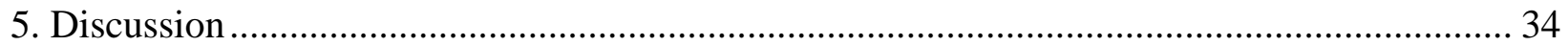

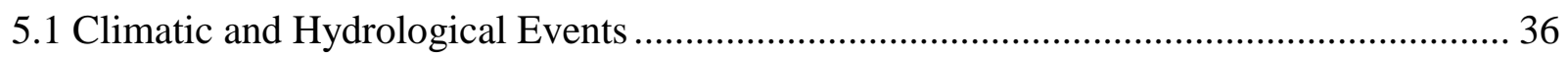

5.1.1 MIS 6 and the Termination II Glacial-interglacial transition ................................ 36 
5.1.2 MIS 5e

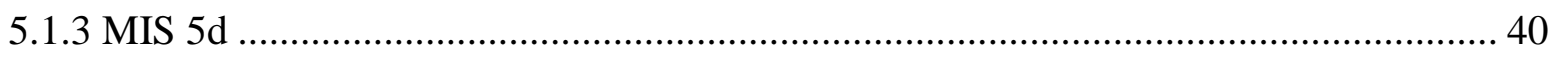

5.2 Dinoflagellate (Paleo) Productivity and Sea Surface Temperature Signal ....................... 40

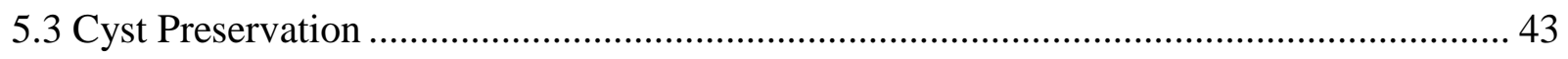

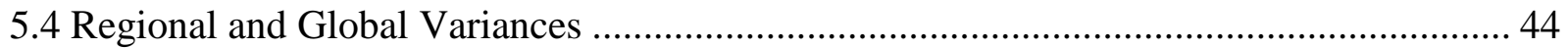

5.5 Comparison of MIS 5e to the Holocene and present ..................................................... 45

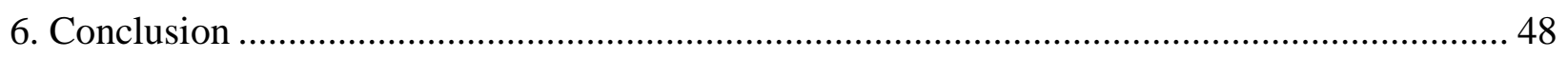

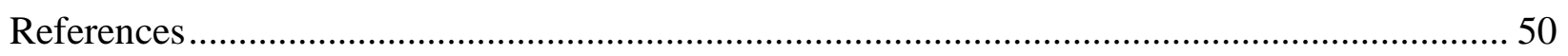

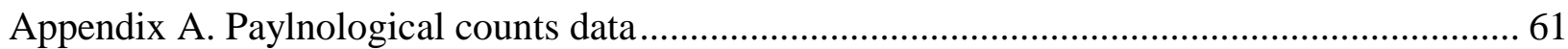




\section{List of Tables}

Table 1. Analyzed sample top (min) and bottom (max) interval (Int) in ODP Hole 893A, uncorrected (uncorr) and corrected (corr) depths, dates, University of Victoria sample ID and numbers, the total concentrations (conc.) and counts of pollen/spores and dinoflagellate cysts, as well as counts of cysts produced by autotrophic (auto.) and heterotrophic (hetero.)

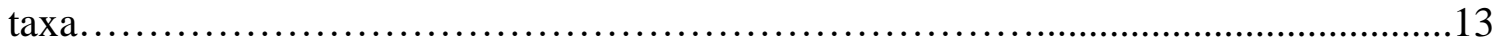

Table 2. Taxonomic citation of dinoflagellate cysts used in this study.....................27

Table 3. Summary of dinoflagellate cyst zone average Principle Component (PC) axis values, cyst concentrations (conc.), ratio, species richness and Shannon-Weiner Index (SWI), as

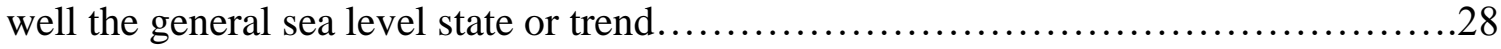




\section{List of Figures}

Figure 1. A) Map showing the location of ODP sites mentioned in the text with a $120 \mathrm{~m}$ bathymetric contour and major surface currents affecting the Santa Barbara Basin area; red and blue arrows represent relatively warm and cold currents, respectively. Black box indicates location of B) showing the bathymetry and location of Hole 893A in the Santa Barbara Basin. The light gray indicates the land exposed during the glacial maximum when global sea level was $\sim 120 \mathrm{~m}$ lower (SL data are from Siddall et al.,

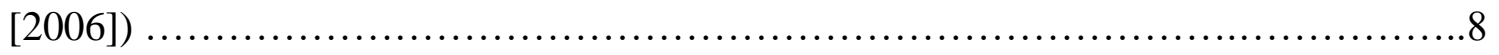

Figure 2. Relative abundances $(\%)$ of selected dinoflagellate cyst taxa that contribute more than $1.5 \%$ in at least one cyst assemblage plotted downcore with the age. Marine Isotope Stages (MIS), color coordinated dinoflagellate cyst zones distinguished by dotted lines plotted across the diagram, and cyst counts are to the left; the disputed range of MIS 5e is highlighted in dark grey (see text). Cysts produced by autotrophic taxa are shown in white and cysts produced by heterotrophic dinoflagellates are shown in grey. The concentration of total Brigantedinium is shown juxtaposed on the \% plot in dark grey. Extinct taxa Hystrichokolpoma spp. and Spiniferites type $\mathrm{S}$ are shown by dots to indicate their presence in samples. To the right are sample scores from the principle component analysis (PCA)

Figure 3. Sample position is given next to the general lithostratigraphy of Hole 893A. Total concentrations of pollen and spores, ratio of cysts to pollen/spores, total concentrations of foraminiferal linings, species richness (solid line with zonal avg. in red) and ShannonWeiner Index (SWI) diversity measurements (dashed line), total concentrations of reworked cysts, cysts produced by autotrophic dinoflagellates with contribution of Operculodinium centrocarpum in blue and Spiniferites mirabilis in red, and cysts produced by heterotrophic dinoflagellates. The diagram also illustrates the downcore ratio of heterotrophic to autotrophic (H:A) cysts to the previously published Hole 893A data of biogenic silica (\%) [Friddell et al., 2002], planktonic foraminifera $\delta^{18} \mathrm{O}$ [Friddell et al., 2002], benthic foraminifera $\delta^{18} \mathrm{O}$ [Kennett, 1995], total organic carbon (TOC, \%) and percent calcium carbonate $\left(\mathrm{CaCO}_{3}, \%\right)$ with 10 point running averages [Gardner and Dartnell, 1995; Stein and Rack, 1995], as well as a global sea level curve modified from Kopp et al., [2009]. Cyst based quantitative reconstructions of annual primary productivity (PP) and August and February sea surface temperature (SST) are shown in black, colored lines indicate a 3 point running average and the grey borders indicate the confidence interval .25

Figure 4. Results of principle components analysis (PCA) with biplot of dinoflagellate cyst taxa (black arrows) and ordination of samples with the color and shape associated with their dinoflagellate cyst zone; bordered shapes belong to transitional samples. General inferred conditions are labelled by axis; the first PC axis represents $33.4 \%$ of the variance and is 
associated with SST and the second PC axis represents $13.5 \%$ and is partially explained by sea level.

Figure 5. A) Previously published alkenone reconstructed SST values from ODP Holes 1016C and 1014A [Yamamoto et al., 2007], 893A [Herbert et al., 1995], and 1012B [Herbert et al., 2001] on the California margin (see Figure 1A). Solid lines represent records from MIS 6 and 5 and dashed lines represent records from MIS 2 and 1. Dinoflagellate cyst zones (DCZ) from ODP Hole 893A [Pospelova et al., 2006] and ODP Hole 1017E [Pospelova et $a l ., 2015$ ] are coloured to represent similarities in assemblage interpretation with this study and are plotted above in correspondence to the ages of MIS 2 and 1, while the DCZ and relative abundance (\%) of thermophyllic taxon Spiniferites mirabilis (this study) are plotted below along the MIS 6 and 5 timescale. B) MIS 6 and 5 benthic foraminifera $\delta^{18} \mathrm{O}$ records from ODP Holes 1017E [Kennett et al., 2000], 1014A [Hendy and Kennett, 2000], and 1012B [Andreasen et al., 2000] with the summer insolation curve [Berger 1978] plotted for reference............................................................ 35 


\section{List of Plates}

Plate I. Bright field photomicrographs of selected autotrophic dinoflagellate cysts. A-B, Bitectatodinium tepikiense, sample UVic 2018-2, sl. 1. C-D, Habibacysta tectata?, sample UVic 2018-32. sl. 1. E-G, ?Hystrichokolpoma spp., sample UVIC 2018-32, sl. 1. H, Impagidinium aculeatum, sample UVic 2018-32, sl. 1. I-J, Impagidinium? paradoxum, sample UVic 2018-10, sl. 1. K-L, Lingulodinium machaerophorum, sample UVic 2018-

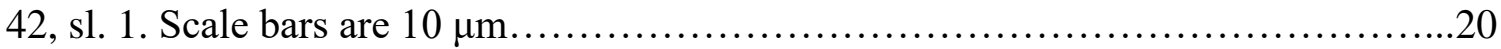

Plate II. Bright field photomicrographs of selected autotrophic dinoflagellate cysts. A, Nematosphaeropsis labyrinthus, sample UVic 2018-6, sl. 1. B, Operculodinium centrocarpum, sample UVic 2018-55, sl. 1. C-D, Operculodinium janduchenei, sample UVic 2018-42, sl. 1. E-F, Polysphaeridium zoharyi, sample UVic 2018-34, sl. 1. G, Spiniferites spp., sample UVic 2018-39, sl. 1. H-I, Spiniferites bentorii, sample UVic 201821, sl. 1. J-K, Spiniferites hyperacanthus, sample UVic 2018-32, sl. 1. L, Spiniferites mirabilis, sample UVic 2018-11, sl. $1 . \quad$ Scale bars are 10

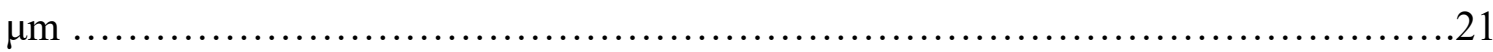

Plate III. Bright field photomicrographs of selected autotrophic dinoflagellate cysts. A-C, Spiniferites pachydermus, sample UVic 2018-21, sl. 1. D-F, Spiniferites type S, sample UVic 2018-23, sl. 1. G-I, Tectatodinium? pellitum, sample UVic 2018-42 sl. 1 and UVic

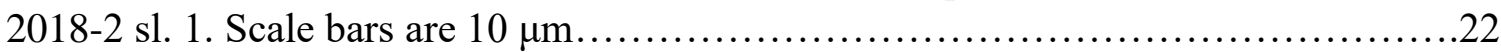

Plate IV. Bright field photomicrographs of selected heterotrophic dinoflagellate cysts. A, Brigantedinium cariacoense, sample UVic 2018-34, sl. 1. B, Brigantedinium simplex, sample UVic 2018-18, sl. 1. C, Dubridinium spp., sample UVic 2018-32, sl. 1. D, Echinidinium cf. delicatum, sample UVic 2018-40, sl. 1. E, Cyst of Protoperidinium americanum, sample UVic 2018-6, sl. 1. F, Quinquecuspis concreta, sample UVic 201836, sl. 1. G, Selenopemphix nephroides, sample UVic 2018-31, sl. 1. H-I, Selenopemphix quanta, sample UVic 2018-10 sl.1 and UVic 2018-40, sl.1. J, Selenopemphix undulata, sample UVic 2018-26, sl. 1. K, Trinovantedinium type S, sample UVic 2018-38, sl. 1. L, Trinovantedinium variabile, sample UVic 2018-37, sl. 1. Scale bars are $10 \mu \mathrm{m} . . . \ldots \ldots . . .23$

Plate V. Selected bright field photomicrographs of known and unknown palynomorphs. A, unknown palynomorph type P, UVic 2018-30, sl. 1. B, reworked extinct dinoflagellate cyst? type Y, sample UVic 2018-55, sl. 1. C, reworked extinct dinoflagellate cyst? type N, sample UVic 2018-53, sl. 2. D-E, ?Globorotunda, sample UVic 2018-55, sl. 1. F, unknown palynomorph type Z, sample UVic 2018-13, sl. 1. G, Mandible, sample UVic 2018-6, sl. 1. H, Copepod egg, sample UVic 2018-3, sl. 1. I, Prasinophyte, sample UVic 2018-53, sl. 2. J, Foraminifera organic lining, sample UVic 2018-13, sl. 1. K, unknown palynomorph type C, sample UVic 2018-3, sl. 1. L, unknown palynomorph type D, sample UVic 201813, sl. 1. Scale bars are $10 \mu \mathrm{m}$. 


\section{Acknowledgements}

Sediment samples were provided by the Integrated Ocean Drilling Program (IODP). We thank C. Broyles and P. Rumford for their assistance in subsampling the sediments. Funding for this research was provided by the Natural Science and Engineering Research Council of Canada (NSERC) to V.P. (Grant RGPIN/6388-2015). Graduate research of JS.O was supported by the University of Victoria graduate fellowship and the Arne Lane Graduate Fellowship. 


\section{Dedication}

Thank you to the constant support of my family, all the new friends I have made during my time in Victoria, and to my advisor who has given me a new found appreciation for the world of dinoflagellate cysts.

For science, for discovery, for the future things to come. 


\section{Introduction}

Anthropogenic influences and natural variability lend towards uncertainty in future climate developments. Mediated mainly by paleoenvironmental reconstructions, which can offer a baseline reference for natural climate transitions, climatic optimums coupled with their associated glacial termination and inception are key intervals to detect consequential hydrological and ecological shifts. Within the Quaternary, the last or most recent "warm" interglacial (LIG) with temperatures similar to current projected climate change is associated with Marine Isotope Stage (MIS) substage 5e, which is climostratigraphically equivalent in publications to the Eemian in Europe, as based on terrestrial vegetation changes [e.g. Shackleton et al., 2003; Goni et al., 2005]. As an analog for the Holocene and future warming, MIS 5e is often considered a good fit [e.g. Kukla et al., 1997] and is the most commonly well preserved climactic optimum in the sedimentary record with major geographical and biotic similarities to the present. Variation in the environmental reconstructions of the LIG on a regional scale supports further documentation and is important in providing information on the response of the northeastern Pacific to Quaternary climate trends.

\subsection{Marine Isotope Stage 5e and the Pacific Northwest}

Differences in the inception and duration of the LIG are debated; the Atlantic and Pacific signals of the optimum differ and are not fully explained by age model discrepancies. The global LR04 benthic $\delta^{18} \mathrm{O}$ stack [Lisecki and Raymo, 2005] recognizes MIS 5e from $~ 130-116$ thousand years B.P (kyr), a 14 kyr duration compared to the orbitally tuned SPECMAP timescale from 129.8$118 \mathrm{kyr}(\sim 11 \mathrm{kyr})$. On the Pacific coast the LIG spans $\sim 140-122 \mathrm{kyr}(\sim 18 \mathrm{kyr})$ at the Devils Hole speleothem [Winograd et al., 1997] and the U-Th based chronology of ODP Hole 893A used in this study spans $\sim 135-116$ kyr ( 19 kyr) [Fridell et al., 2002]. The global characterization of MIS 
5e is generally accepted, where the air temperature was $\sim 1-2^{\circ} \mathrm{C}$ warmer than present based on the Vostok ice core [e.g. Petit et al., 1999] and global sea level fluctuated on the order of $\sim 3-9 \mathrm{~m}$ above present during the climactic optimum following a two-step $\sim 120 \mathrm{~m}$ rise after the MIS 6 glaciation [Siddall et al., 2006; Hearty et al., 2007; Kopp et al., 2009]. There is not a clear consensus on interglacial stability; marine and terrestrial records from Asia [e.g. Granoszweski et al. 2005], north and equatorial Atlantic [e.g. Maslin et al., 1996; Helmens et al., 2015], and the north-central California margin [Poore et al., 2000] suggest brief mid substage cold periods between 122-126 kyr, but records from Europe [e.g. Brewer et al., 2008] and the California margin [e.g. Heusser, 2000] remain continuously warm.

Previous studies along the California margin, and specifically in the Santa Barbara Basin (SBB), have paleoceanographic records with detailed information on Holocene and Pleistocene climate variability [e.g. Kennett et al., 1994; Hendy and Kennett, 2000; Heusser, 2000; Pospelova et al., 2006; Fisler and Hendy, 2008]. Sea surface temperature (SST) reconstructions in the region from marine sources vary by proxy; on the California margin the use of alkenone-based methods are argued to record SST corresponding to annual averages for sediment collected nearshore and SST closer to the winter average for sediment collected offshore [Doose et al., 1997; Herbert et al., 1998]. Foraminiferal SST reconstructions are related to the species water depth preference and seasonality [e.g. Epstein et al., 1953; Hendy and Kennett, 1999; Friddell et al., 2002]. Terrestrial warming is assumed to be synchronous with SST warming in the SBB, which derived from alkenone unsaturation indices and planktonic foraminiferal $\delta^{18} \mathrm{O}$ yield a SST warming of $7-8^{\circ} \mathrm{C}$ and $4.2-9.2^{\circ} \mathrm{C}$, respectively, across Termination II with peak SSTs reaching $\sim 19^{\circ} \mathrm{C}$ [Herbert et al., 1995; Friddell et al., 2002]. Pollen records indicate a terrestrial transition from wet and cool conditions to warm and dry starting at $\sim 140 \mathrm{kyr}$ [Friddell et al., 2002]. Warmer temperatures than 
the modern along the Californian coast are corroborated to the south by incursion of tropical molluscan fauna [Muhs et al., 2001] and alkenone and foraminifera records from ODP sites 1014 and 1012. To the north, similar records from ODP sites 1017 and 1016 indicate SST warming 2 to $4^{\circ} \mathrm{C}$ above modern values [Kreitz et al., 2000; Poore et al., 2000]. However, the planktonic foraminifer record is incomplete during the MIS 5e plateau, and their $\delta^{18} \mathrm{O}$ geochemical signal cannot separate the thermal and salinity contributions. The benthic and planktonic foraminifer $\delta^{18} \mathrm{O}$ record is also essentially a measure of ice volume changes or the terrestrial fingerprint on the basins surface waters and requires an independent marine SST proxy to compare rates of change between land and sea [e.g. Broecker, 1993]. The available data in the SBB also lacks a proxy capable of distinguishing seasonal SST changes. Primary productivity proxies previously studied in the SBB include biogenic opal (\%) and total organic carbon (TOC \%) [Friddell et al., 2002; Gardner and Dartnell, 1995]. The records are inconsistent with each other especially during the latest part of MIS 5e, and as a proxy for primary productivity, data reported in relative abundances instead of concentrations cannot give as accurate a quantification of productivity. The use of $\%$ opal also assumes siliceous based productivity is the only or major contribution to total annual primary production.

\subsection{Dinoflagellate Cysts}

Modern dinoflagellates are one of the most diverse groups of phytoplankton in coastal environments and represent a major proportion of primary producers alongside diatoms and coccolithophores. Unlike their siliceous and calcareous contemporaries, the resting (cyst) stage produced by $13-16 \%$ of autotrophic and heterotrophic dinoflagellates is often made of dinosporin, an organic polymer resistant to dissolution and well preserved in the fossil record [e.g. Dale, 1976; 
Head, 1996; MacRae et al., 1996; Versteegh and Blokker, 2004]. Studies of modern dinoflagellate cysts have identified primary productivity (PP), SST, sea surface salinity (SSS), eutrophication, and sea ice cover of water masses as parameters affecting the distribution of cysts in underlying surface sediments [e.g. Harland, 1983; Dale 1996; de Vernal et al., 1997; Rochon et al., 1999; Pospelova et al., 2004, 2005; Radi et al., 2007; Zonneveld et al., 2013; Ellegaard et al., 2017; Price et al., 2018]. Specifically, cysts produced by heterotrophic taxa operate as proxies for PP, as their main diet consists of diatoms and other small ciliates [e.g. Jacobson and Anderson, 1996]. It was shown that multivariate statistical analyses performed with paleo and modern cyst assemblages could be used to reconstruct these parameters in the Late Quaternary [e.g. de Vernal et al., 2001, 2005, 2013; Radi and de Vernal, 2008; Pospelova et al., 2015; Aubry et al., 2016; Hardy et al., 2018]. Most of these studies were focused on the LGM and the Holocene in the North Atlantic, and published data on dinoflagellate cysts during the LIG are less common in general and are again mainly located in the North Atlantic [e.g. Goni et al., 2000; Eynaud et al., 2004; Head et al., 2005; Van Nieuwenhove and Bauch, 2008] with additional studies from in the Black Sea [Shumulovskikh et al., 2013] and eastern Yellow Sea [Chang et al., 2013].

Along the northeastern Pacific margin a few papers have high resolution (i.e. submillennial) geochemical or complete microfossil records of MIS 5e [Poore et al., 2000; Pisias et al., 2001], and the studies that document dinoflagellate cysts across interglacial and glacial periods in this area were conducted at a very low resolution [Marret et al., 2001; Byrne et al., 1990] or are restricted to the last $\sim 42 \mathrm{kyr}$ [Pospelova et al., 2006, 2015; Price et al., 2013]. In this work, the dinoflagellate cyst record from Ocean Drilling Program (ODP) Hole 893A in the SBB was used to (1) reconstruct changes in PP, SST, SSS qualitatively and quantitatively from $\sim 155-110$ kyr using the dinoflagellate cyst record; (2) compare the paleoenvironmental interpretations of the 
glacial-interglacial evolution with other geochemical and paleontological records at and near the site; (3) evaluate the regional and global expression of the paleoclimatic signals; and (4) compare our newly obtained dinoflagellate cyst data from MIS 6-5d with previously published results in the SBB spanning the Holocene [Pospelova et al., 2006, 2015; Bringué et al., 2014]. 


\section{Environmental Setting}

The SBB is a well-studied semi-enclosed basin on the northern end of the Southern California Bight (Figure 1A). The SBB reaches a maximum water depth of $589 \mathrm{~m}$ and is bounded by the Channel Islands to the south, a $\sim 230 \mathrm{~m}$ deep sill to the east, and a $\sim 470 \mathrm{~m}$ deep sill to the west [e.g. Emery, 1960; Eichhubl et al., 2002]. During MIS 6 and 2 global sea level lowstands $~ 120 \mathrm{~m}$ below modern sea level noticeably lowered the volume of water in the basin and exposed land that connected the Channel Islands into one larger island, which restricted water access into the basin from the eastern sill (Figure 1B) [e.g Siddall et al., 2006; Meyers et al., 2015]. The regional vegetation cover is controlled by the mild wet winters and dry summers moderated by fog formation; the narrow coastal plain is dominated by sage scrub and chaparral, while the higher altitude woodland savannah and foothills are primarily oak, and highest elevation is pine forest and juniper woodland [Heusser, 1995]. During glacial periods cooler temperatures and increased precipitation in a still overall arid climate saw an increase in conifer forests. Riverine input into the basin was limited to minor tributaries that drained the Santa Ynez Mountains and the Ventura and Santa Clara rivers on the far eastern part of the basin, which limited the potential for widespread freshwater stratification in the basin surface waters. The central SBB has as average high sedimentation rate of $\sim 1-4 \mathrm{~mm} \mathrm{yr}^{-1}$ [e.g. Koide et al., 1972; Kennett, 1995] and is composed primarily of fine-grained lithogenic material sourced from runoff and seismic or wave remobilization of sediment along the shelf, and was delivered to the center of the basin in higher amounts during times of high productivity, of which biogenic accumulation of opal, carbonate, and organic carbon contribute to the remainder of the sediment flux [e.g. Dunbar and Berger, 1982; Thunell, 1998]. Laminated sediments in the basin are interpreted as oxygen-deficient intervals of deposition brought on by a lack of ventilation of the oxygen depleted Pacific Intermediate Water 
(PIW) present in the deep parts of the basin [e.g. Sholkovitz and Gieskes, 1971] and/or periods of high productivity, and are recorded in the SBB throughout the Holocene ( 11 kya to present) and intermittently through the Pleistocene whereas massive bioturbated sequences indicate extended oxygenated conditions in the basin recorded during the Last Glacial Maximum and the majority of the sequence [e.g. Kennett and Ingram, 1995; Behl and Kennett, 1996]. Productivity shifts along the California margin over the past $\sim 60 \mathrm{kyr}$ follow submillenial climatic events; upwelling and enhanced primary productivity was active during warm interstadial events of MIS 3 and the Bølling, while cool stadial events of MIS 3, the Allerød, and Younger Dryas were characterized by less productive waters [e.g. Hendy et al., 2005; Ivanochko and Pederson, 2004; Pospelova et al., 2015]. 

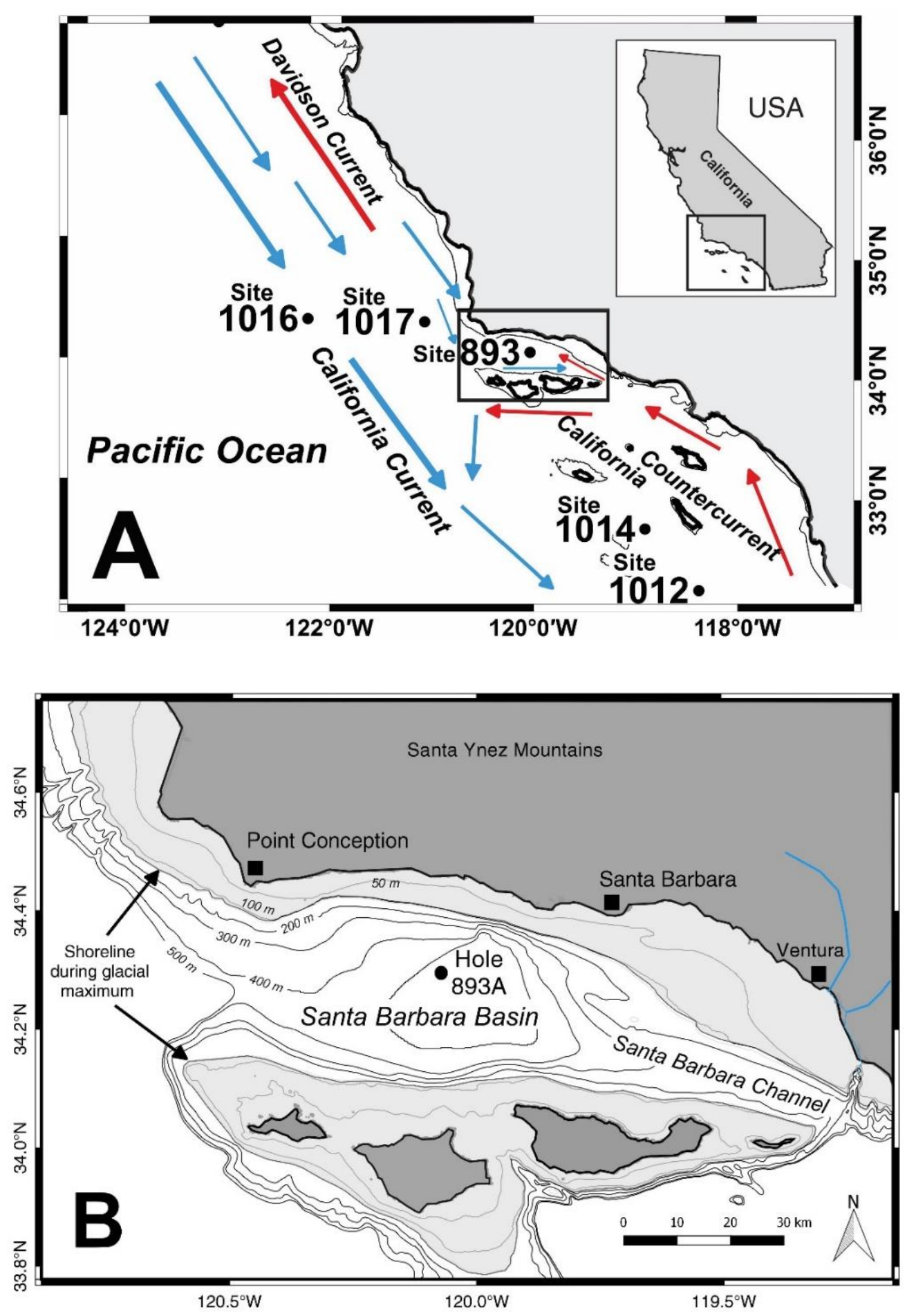

Figure 1. A) Map showing the location of ODP sites mentioned in the text with a $120 \mathrm{~m}$ bathymetric contour and major surface currents affecting the Santa Barbara Basin area; red and blue arrows represent relatively warm and cold currents, respectively. Black box indicates location of B) showing the bathymetry and location of ODP Hole 893A in the Santa Barbara Basin. The light gray indicates the land exposed during the glacial maximum when global sea level was $\sim 120$ m lower (SL data are from Siddall et al., [2006]). 
The modern hydrology of the basin is controlled by the northward flowing California Countercurrent and Davidson Current, and the southward flowing California Current [Hickey, 1998]. Seasonal circulation is dependent on wind patterns and strength and is expressed in three characteristic flow patterns; the upwelling pattern occurs in late Spring when strong northerly winds enhance equatorward flow at the surface and at $45 \mathrm{~m}$ depth, the surface convergent pattern occurs in summer when continued upwelling and buildup of pressure gradients along the shore create a westward surface flow converging at Point Conception, and the relaxation pattern occurs in winter when upwelling favorable winds end and the enhanced California Undercurrent brings warm, nutrient-rich, and oxygen-poor water into the basin [Lynn and Simpson, 1987; Winant et al., 2003]. The temporal and spatial circulation fluxes create patterns of phytoplankton productivity in the basin that peak in early spring and have occasional highs in summer and fall [Shipe and Brzezinski, 2003], where the spring productivity mean, from cruises in 2001 to 2006 , was $3.1 \pm$ $1.5 \mathrm{gC} \mathrm{m}^{-2} \mathrm{~d}^{-1}$ and the winter mean was $1.3 \pm 0.6 \mathrm{gC} \mathrm{m}^{-2} \mathrm{~d}^{-1}$ [Brzezinski and Washburn, 2011]. Modern SST in the SBB are warmest during the fall (August-October) and the average for these months was $18.7^{\circ} \mathrm{C}$ in $2017,1.3^{\circ} \mathrm{C}$ higher than the $1994-2008$ avg. for the same months, while the coolest SST occur during the upwelling season (March-April) and the average for these months was $13.4^{\circ} \mathrm{C}$ in $2018,0.2^{\circ} \mathrm{C}$ higher than the $1994-2008$ avg. for the same months (https://www.ndbc.noaa.gov/station_history.php?station=46053). 


\section{Materials and Methods}

Samples in this study were collected in 1992 from ODP Leg 146 Hole 893A $\left(34^{\circ} 17.25^{\prime} \mathrm{N}, 120^{\circ}\right.$ 2.20 W). This site is in the deepest part of the central Santa Barbara Basin (Figure 1B). The 196.5 m section recovered spans the late Quaternary from $\sim 160 \mathrm{kyr}$ to the present and consists of intercalated bioturbated and laminated olive-grey clay and silt with a few sand layers [e.g. Behl, 1995].

The age model used in this study is based on benthic $\delta^{18} \mathrm{O}$ from the same core (ODP Hole 893A), SPECMAP, three U-Th dates [Fridell et al., 2002 and references therein], and has been corrected for voids and grey layers that represent turbidite and flood deposits in the core. Subsequent comparisons of other geochemical proxies from the same core have been adjusted appropriately if a previous age model was used. Regardless of the absolute timing, by using multiple records from the same core the phases and transitions across proxies can be determined unambiguously.

\subsection{Palynological Sample Preparation and Microscopy}

Fifty-seven sediment samples $1 \mathrm{~cm}$ thick $\left(1.4-2.75 \mathrm{~cm}^{3}\right)$ were selected from core sections $15 \mathrm{H}$ $20 \mathrm{H}$ in the lower part of ODP Hole 893A for dinoflagellate cyst analysis (Table 1). Sediment slices targeted at MIS 5e were subsampled at $\sim 0.5 \mathrm{~m}$ intervals with an average of $0.57 \mathrm{~m}$ representing a resolution of $0.27-1.53 \mathrm{kyr}$. Six of the samples were analyzed at a lower resolution ( $2 \mathrm{~m}$ intervals $)$ to characterize the contrasting conditions of MIS 6 and MIS 5d.

Dinoflagellate cysts, foraminiferal organic linings, pollen grains, and spores were recovered using a standardized preparation technique [e.g. Pospelova et al., 2005, 2010]. Samples of known volume were oven-dried at $\sim 40^{\circ} \mathrm{C}$ and then weighed. Two tablets (batch \#3682) of exotic 
Lycopodium clavatum spores were added in order to calculate concentrations of palynomorphs based on dry weight of sediments [e.g. Stockmarr, 1971; Mertens et al., 2009, 2012]. Samples were then treated with $10 \% \mathrm{HCl}$ to remove carbonates and sieved through $120 \mu \mathrm{m}$ and retained on $15 \mu \mathrm{m}$ Nitex nylon mesh to eliminate coarse and fine material. Siliceous material was removed with room temperature $48 \% \mathrm{HF}$ acid for up to a week followed by a second $10 \% \mathrm{HCl}$ treatment to remove precipitated fluorosilicates [e.g. Price et al., 2016]. Samples were then rinsed with distilled water, sonicated for $30 \mathrm{sec}$ before the second sieving through a $15 \mu \mathrm{m}$ Nitex nylon mesh, having been centrifuged between each step. No oxidizing reagents were used to prevent the loss of more fragile dinoflagellate cysts, as cysts formed by Protoperidinium and Echinidinium genera are selectively more sensitive than gonyaulacoid cysts to degradation under sustained oxidizing conditions [e.g. Dale, 1976; Marret, 1993; Zonneveld et al., 1997, 2007, 2008, 2010; Hopkins and McCarthy, 2002; Mertens et al., 2009; Gray et al., 2017]. Residue was mounted between a glass slide and coverslip in glycerin gel for microscopic observation. All microscope slides and residues are stored in the Paleoenvironmental Laboratory, University of Victoria, Canada.

For each sample a minimum of 300 dinoflagellate cysts were targeted for statistical robustness; the one sample (UVic ID 2018-8) with <20 cysts was not included in the analyses but is present on abundance and concentration plots (Figure 2 and 3). Pollen counts were also targeted at 300 grains while total spores and foraminiferal linings were enumerated; pollen grains were distinguished between bisaccate (e.g. Pinus and Abies) and nonbisaccate (e.g. Quercus and Asteracea), while other palynomorphs were not identified further. When referring to the cyst to pollen ratio in the rest of the paper, "pollen" refers to combined pollen \& spores. To analyze changes in dinoflagellate cysts in the sequence, assemblages are reported in relative abundances 
$(\%)$ and total cyst concentrations (cysts $\left.\mathrm{g}^{-1}\right)$. The sedimentation rates at this time interval are not reliably constrained for the calculations of cyst fluxes.

Dinoflagellate cysts were identified at either 600x or 1000x magnification according to the descriptions and taxonomy given in Lentin and Williams [Williams et al., 2017] and conforms to the cyst nomenclature of Head [2007] and Zonneveld and Pospelova [2015]. Some dinoflagellate taxa are grouped together on the basis of rarity, morphological similarities, and/or environmental affiliation. Notably, Brigantedinium spp. (B. cariacoense and B. simplex) are grouped together because folding or unfavorable orientation obscures the distinguishing archeopyle, which prevents identification to the species level. The group "Spiny Brown" includes characteristic Echinidinum spp. and brown cysts smaller than $30 \mu \mathrm{m}$ with numerous tapering processes that could not be positively identified as Selenopemphix quanta. Spiniferites mirabilis includes cysts of Spiniferites hyperacanthus, as both species represent similar environmental conditions and identification of the "crown" that separates the two species is not always visible or favorably orientated. The grouping of Impagidinium spp. and N. labyrinthus into "oceanic Taxa" is made on the basis of their rare occurrences and they represent similar open oceanic conditions. Reworked cysts are identified based on their distinct yellow appearance and are recorded separately as they may indicate a change in sea-level or currents [e.g. Streel and Bless 1980], but are not used in total cyst counts or statistical analyses. 
Table 1. Analyzed sample top (min) and bottom (max) interval (Int) in ODP Hole 893A, uncorrected (uncorr) and corrected (corr) depths, dates, University of Victoria sample ID and numbers, the total concentrations (conc.) and counts of pollen/spores and dinoflagellate cysts, as well as counts of cysts produced by autotrophic (auto.) and heterotrophic (hetero.) taxa.

\begin{tabular}{|c|c|c|c|c|c|c|c|c|c|c|c|c|c|c|}
\hline & Leg & Hole & Core & $\begin{array}{l}\text { Int } \\
\text { min } \\
(\mathrm{cm}) \\
\end{array}$ & $\begin{array}{c}\text { Int } \\
\max \\
(\mathbf{c m}) \\
\end{array}$ & $\begin{array}{c}\text { Depth } \\
\text { uncorr } \\
(\mathbf{m b s f m})\end{array}$ & $\begin{array}{c}\begin{array}{c}\text { Depth } \\
\text { corr } \\
\text { (mbsfm) }\end{array} \\
\end{array}$ & $\begin{array}{l}\text { Age }^{a} \\
(k y r)\end{array}$ & UVic ID & $\begin{array}{c}\text { Total pollen } \\
\text { \& spores } \\
\text { conc }^{\mathrm{b}}\end{array}$ & $\begin{array}{c}\text { Pollen } \\
\text { \& spore } \\
\text { counts }\end{array}$ & $\begin{array}{c}\text { Total } \\
\text { dinocyst } \\
\text { conc }^{c}\end{array}$ & $\begin{array}{c}\text { Auto. } \\
\text { cyst } \\
\text { counts }\end{array}$ & $\begin{array}{c}\text { Hetero. } \\
\text { cyst } \\
\text { counts }\end{array}$ \\
\hline 1 & 146 & $893 \mathrm{~A}$ & $15 \mathrm{H}-4$ & 77 & 78 & 135.34 & 132.75 & 109.19 & $2018-1$ & 23831 & 323 & 3877 & 49 & 288 \\
\hline 2 & 146 & $893 \mathrm{~A}$ & $15 \mathrm{H}-5$ & 119 & 120 & 137.37 & 134.78 & 111.98 & $2018-2$ & 32838 & 330 & 5856 & 22 & 287 \\
\hline 3 & 146 & $893 \mathrm{~A}$ & $15 \mathrm{H}-6$ & 59 & 60 & 138.39 & 135.79 & 113.41 & $2018-3$ & 14862 & 322 & 14816 & 9 & 314 \\
\hline 4 & 146 & $893 \mathrm{~A}$ & $15 \mathrm{H}-7$ & 10 & 11 & 139.40 & 136.77 & 114.80 & $2018-4$ & 27077 & 339 & 7295 & 17 & 305 \\
\hline 5 & 146 & $893 \mathrm{~A}$ & $16 \mathrm{H}-1$ & 10 & 11 & 139.60 & 137.30 & 115.55 & $2018-5$ & 20864 & 354 & 6371 & 9 & 298 \\
\hline 6 & 146 & $893 \mathrm{~A}$ & $16 \mathrm{H}-1$ & 60 & 61 & 140.10 & 137.70 & 116.11 & $2018-6$ & 18806 & 238 & 14296 & 23 & 373 \\
\hline 7 & 146 & $893 \mathrm{~A}$ & $16 \mathrm{H}-1$ & 130 & 131 & 140.80 & 138.26 & 116.91 & 2018-7 & 25203 & 365 & 7712 & 23 & 300 \\
\hline 8 & 146 & $893 \mathrm{~A}$ & $16 \mathrm{H}-2$ & 32 & 33 & 141.32 & 138.73 & 117.57 & $2018-8$ & 14215 & 220 & 217 & 2 & 12 \\
\hline 9 & 146 & $893 \mathrm{~A}$ & $16 \mathrm{H}-2$ & 83 & 84 & 141.83 & 139.24 & 118.29 & $2018-9$ & 19885 & 314 & 12662 & 12 & 313 \\
\hline 10 & 146 & $893 \mathrm{~A}$ & $16 \mathrm{H}-2$ & 133 & 134 & 142.33 & 139.74 & 119.01 & 2018-10 & 18307 & 339 & 9663 & 35 & 319 \\
\hline 11 & 146 & $893 \mathrm{~A}$ & $16 \mathrm{H}-3$ & 38 & 39 & 142.88 & 140.26 & 119.74 & 2018-11 & 26104 & 325 & 9967 & 52 & 294 \\
\hline 12 & 146 & $893 \mathrm{~A}$ & $16 \mathrm{H}-3$ & 87 & 88 & 143.37 & 140.75 & 120.43 & 2018-12 & 16151 & 345 & 7747 & 25 & 310 \\
\hline 13 & 146 & $893 \mathrm{~A}$ & $16 \mathrm{H}-3$ & 129 & 130 & 143.79 & 141.17 & 120.98 & 2018-13 & 18019 & 316 & 10766 & 35 & 275 \\
\hline 14 & 146 & $893 \mathrm{~A}$ & $16 \mathrm{H}-4$ & 18 & 19 & 144.32 & 141.70 & 121.58 & 2018-14 & 15238 & 321 & 18578 & 26 & 300 \\
\hline 15 & 146 & $893 \mathrm{~A}$ & $16 \mathrm{H}-4$ & 67 & 68 & 144.81 & 142.19 & 122.13 & 2018-15 & 8758 & 138 & 21020 & 21 & 331 \\
\hline 16 & 146 & $893 \mathrm{~A}$ & $16 \mathrm{H}-4$ & 118 & 119 & 145.32 & 142.70 & 122.71 & 2018-16 & 15129 & 326 & 16289 & 18 & 351 \\
\hline 17 & 146 & $893 \mathrm{~A}$ & $16 \mathrm{H}-5$ & 17 & 18 & 145.85 & 143.22 & 123.29 & 2018-17 & 8946 & 309 & 8872 & 44 & 302 \\
\hline 18 & 146 & $893 \mathrm{~A}$ & $16 \mathrm{H}-5$ & 67 & 68 & 146.35 & 143.72 & 123.86 & 2018-18 & 7905 & 322 & 5068 & 38 & 318 \\
\hline 19 & 146 & $893 \mathrm{~A}$ & $16 \mathrm{H}-5$ & 117 & 118 & 146.85 & 144.22 & 124.42 & 2018-19 & 6532 & 304 & 5295 & 37 & 280 \\
\hline 20 & 146 & $893 \mathrm{~A}$ & $16 \mathrm{H}-6$ & 17 & 18 & 147.38 & 144.74 & 125.01 & 2018-20 & 6713 & 252 & 7868 & 15 & 312 \\
\hline 21 & 146 & $893 \mathrm{~A}$ & $16 \mathrm{H}-6$ & 67 & 68 & 147.88 & 145.24 & 125.58 & 2018-21 & 4864 & 307 & 4910 & 34 & 287 \\
\hline 22 & 146 & $893 \mathrm{~A}$ & $16 \mathrm{H}-6$ & 117 & 118 & 148.38 & 145.74 & 126.14 & $2018-22$ & 7222 & 308 & 4131 & 41 & 267 \\
\hline 23 & 146 & $893 \mathrm{~A}$ & $16 \mathrm{H}-7$ & 19 & 20 & 148.90 & 146.20 & 126.66 & $2018-23$ & 6175 & 336 & 5508 & 40 & 286 \\
\hline 24 & 146 & $893 \mathrm{~A}$ & $16 \mathrm{H}-7$ & 74 & 75 & 149.45 & 146.63 & 127.15 & $2018-24$ & 7048 & 309 & 4581 & 25 & 409 \\
\hline 25 & 146 & $893 \mathrm{~A}$ & $17 \mathrm{H}-1$ & 52 & 53 & 149.52 & 147.24 & 127.84 & $2018-25$ & 3960 & 274 & 4498 & 15 & 310 \\
\hline 26 & 146 & $893 \mathrm{~A}$ & $17 \mathrm{H}-1$ & 102 & 103 & 150.02 & 147.74 & 128.40 & $2018-26$ & 5339 & 314 & 5046 & 67 & 260 \\
\hline 27 & 146 & $893 \mathrm{~A}$ & $17 \mathrm{H}-2$ & 2 & 3 & 150.52 & 148.20 & 128.92 & $2018-27$ & 4239 & 255 & 4995 & 15 & 313 \\
\hline 28 & 146 & $893 \mathrm{~A}$ & $17 \mathrm{H}-2$ & 51 & 52 & 151.01 & 148.69 & 129.48 & $2018-28$ & 1523 & 156 & 2229 & 12 & 263 \\
\hline 29 & 146 & $893 \mathrm{~A}$ & $17 \mathrm{H}-2$ & 102 & 103 & 151.52 & 149.20 & 130.05 & 2018-29 & 3649 & 234 & 4575 & 15 & 306 \\
\hline
\end{tabular}




\begin{tabular}{|c|c|c|c|c|c|c|c|c|c|c|c|c|c|c|}
\hline & Leg & Hole & Core & $\begin{array}{l}\text { Int } \\
\text { min } \\
(\mathrm{cm})\end{array}$ & $\begin{array}{c}\text { Int } \\
\max \\
(\mathbf{c m}) \\
\end{array}$ & $\begin{array}{c}\text { Depth } \\
\text { uncorr } \\
(\mathrm{mbsfm})\end{array}$ & $\begin{array}{c}\begin{array}{c}\text { Depth } \\
\text { corr } \\
\text { (mbsfm) }\end{array} \\
\end{array}$ & $\begin{array}{l}\text { Age }^{a} \\
(k y r)\end{array}$ & UVic ID & $\begin{array}{c}\text { Total pollen } \\
\text { \& spores } \\
\text { conc }^{\mathrm{b}}\end{array}$ & $\begin{array}{l}\text { Pollen } \\
\text { \& spore } \\
\text { counts }\end{array}$ & $\begin{array}{c}\text { Total } \\
\text { dinocyst } \\
\text { conc }^{c}\end{array}$ & $\begin{array}{c}\text { Auto. } \\
\text { cyst } \\
\text { counts }\end{array}$ & $\begin{array}{c}\text { Hetero. } \\
\text { cyst } \\
\text { counts }\end{array}$ \\
\hline 30 & 146 & $893 \mathrm{~A}$ & $17 \mathrm{H}-3$ & 2 & 3 & 152.05 & 149.73 & 130.65 & $2018-30$ & 5632 & 327 & 4948 & 23 & 353 \\
\hline 31 & 146 & $893 \mathrm{~A}$ & $17 \mathrm{H}-3$ & 52 & 53 & 152.55 & 150.23 & 131.22 & 2018-31 & 5075 & 243 & 6907 & 20 & 321 \\
\hline 32 & 146 & $893 \mathrm{~A}$ & $17 \mathrm{H}-3$ & 102 & 103 & 153.05 & 150.73 & 131.78 & $2018-32$ & 7697 & 308 & 5287 & 26 & 310 \\
\hline 33 & 146 & $893 \mathrm{~A}$ & $17 \mathrm{H}-4$ & 1 & 2 & 153.64 & 151.27 & 132.39 & $2018-33$ & 2813 & 201 & 4388 & 19 & 304 \\
\hline 34 & 146 & $893 \mathrm{~A}$ & $17 \mathrm{H}-4$ & 50 & 51 & 154.13 & 151.76 & 132.94 & 2018-34 & 13856 & 315 & 7121 & 34 & 282 \\
\hline 35 & 146 & $893 \mathrm{~A}$ & $17 \mathrm{H}-4$ & 100 & 101 & 154.63 & 152.26 & 133.51 & $2018-35$ & 6693 & 266 & 7987 & 38 & 277 \\
\hline 36 & 146 & $893 \mathrm{~A}$ & $17 \mathrm{H}-4$ & 147 & 148 & 155.10 & 152.73 & 134.03 & 2018-36 & 10261 & 312 & 4841 & 24 & 303 \\
\hline 37 & 146 & $893 \mathrm{~A}$ & $17 \mathrm{H}-5$ & 40 & 41 & 155.53 & 153.23 & 134.60 & $2018-37$ & 24996 & 334 & 2430 & 51 & 258 \\
\hline 38 & 146 & $893 \mathrm{~A}$ & $17 \mathrm{H}-5$ & 90 & 91 & 156.13 & 153.73 & 135.16 & $2018-38$ & 21666 & 319 & 3373 & 25 & 295 \\
\hline 39 & 146 & $893 \mathrm{~A}$ & $17 \mathrm{H}-5$ & 138 & 139 & 156.61 & 154.21 & 135.64 & 2018-39 & 13280 & 376 & 1350 & 57 & 275 \\
\hline 40 & 146 & $893 \mathrm{~A}$ & $17 \mathrm{H}-6$ & 44 & 45 & 157.17 & 154.76 & 136.17 & $2018-40$ & 20413 & 322 & 3991 & 22 & 292 \\
\hline 41 & 146 & $893 \mathrm{~A}$ & $17 \mathrm{H}-6$ & 98 & 99 & 157.71 & 155.30 & 136.69 & 2018-41 & 24683 & 366 & 2335 & 11 & 314 \\
\hline 42 & 146 & $893 \mathrm{~A}$ & $17 \mathrm{H}-6$ & 146 & 147 & 158.19 & 155.78 & 137.16 & $2018-42$ & 26526 & 328 & 2621 & 24 & 274 \\
\hline 43 & 146 & $893 \mathrm{~A}$ & $18 \mathrm{H}-1$ & 2 & 3 & 158.52 & 156.24 & 137.60 & $2018-43$ & 13600 & 374 & 3275 & 25 & 299 \\
\hline 44 & 146 & $893 \mathrm{~A}$ & $18 \mathrm{H}-1$ & 52 & 53 & 159.02 & 156.74 & 138.09 & $2018-44$ & 41067 & 308 & 4539 & 41 & 277 \\
\hline 45 & 146 & $893 \mathrm{~A}$ & $18 \mathrm{H}-1$ & 102 & 103 & 159.52 & 157.24 & 138.57 & $2018-45$ & 19084 & 333 & 2503 & 27 & 297 \\
\hline 46 & 146 & $893 \mathrm{~A}$ & $18 \mathrm{H}-2$ & 2 & 3 & 160.02 & 157.69 & 139.01 & $2018-46$ & 20657 & 314 & 2915 & 70 & 262 \\
\hline 47 & 146 & $893 \mathrm{~A}$ & $18 \mathrm{H}-2$ & 60 & 61 & 160.60 & 158.27 & 139.57 & $2018-47$ & 20934 & 344 & 5677 & 20 & 313 \\
\hline 48 & 146 & $893 \mathrm{~A}$ & $18 \mathrm{H}-3$ & 60 & 61 & 162.10 & 159.72 & 140.97 & $2018-48$ & 21670 & 335 & 5663 & 30 & 290 \\
\hline 49 & 146 & $893 \mathrm{~A}$ & $18 \mathrm{H}-3$ & 110 & 111 & 162.60 & 160.22 & 141.46 & $2018-49$ & 20388 & 322 & 4779 & 6 & 302 \\
\hline 50 & 146 & $893 \mathrm{~A}$ & $18 \mathrm{H}-4$ & 110 & 111 & 164.18 & 161.80 & 142.99 & $2018-50$ & 21763 & 342 & 6250 & 8 & 312 \\
\hline 51 & 146 & $893 \mathrm{~A}$ & $18 \mathrm{H}-5$ & 1 & 2 & 164.59 & 162.16 & 143.34 & $2018-51$ & 15624 & 311 & 3935 & 10 & 292 \\
\hline 52 & 146 & $893 \mathrm{~A}$ & $18 \mathrm{H}-6$ & 10 & 11 & 166.18 & 163.70 & 144.61 & $2018-52$ & 22098 & 332 & 4738 & 20 & 410 \\
\hline 53 & 146 & $893 \mathrm{~A}$ & $18 \mathrm{H}-6$ & 60 & 61 & 166.68 & 164.20 & 144.88 & $2018-53$ & 18090 & 434 & 3282 & 17 & 296 \\
\hline 54 & 146 & $893 \mathrm{~A}$ & $19 \mathrm{H}-1$ & 1 & 2 & 168.01 & 165.73 & 145.71 & $2018-54$ & 12807 & 345 & 5444 & 9 & 305 \\
\hline 55 & 146 & $893 \mathrm{~A}$ & $20 \mathrm{H}-1$ & 60 & 61 & 178.10 & 175.50 & 151.27 & $2018-55$ & 27664 & 322 & 2971 & 17 & 302 \\
\hline 56 & 146 & $893 \mathrm{~A}$ & $20 \mathrm{H}-2$ & 110 & 111 & 180.10 & 177.50 & 153.00 & $2018-56$ & 18844 & 309 & 4711 & 26 & 471 \\
\hline 57 & 146 & $893 \mathrm{~A}$ & $20 \mathrm{H}-4$ & 20 & 21 & 182.20 & 179.50 & 155.00 & $2018-57$ & 14732 & 377 & 2936 & 19 & 287 \\
\hline
\end{tabular}

a Age using Friddell et al., [2002] age model

${ }^{b}$ Pollen and spores reported in grains $\mathrm{g}^{-1}$

${ }^{\text {c }}$ Cysts reported in cysts $\mathrm{g}^{-1}$ 


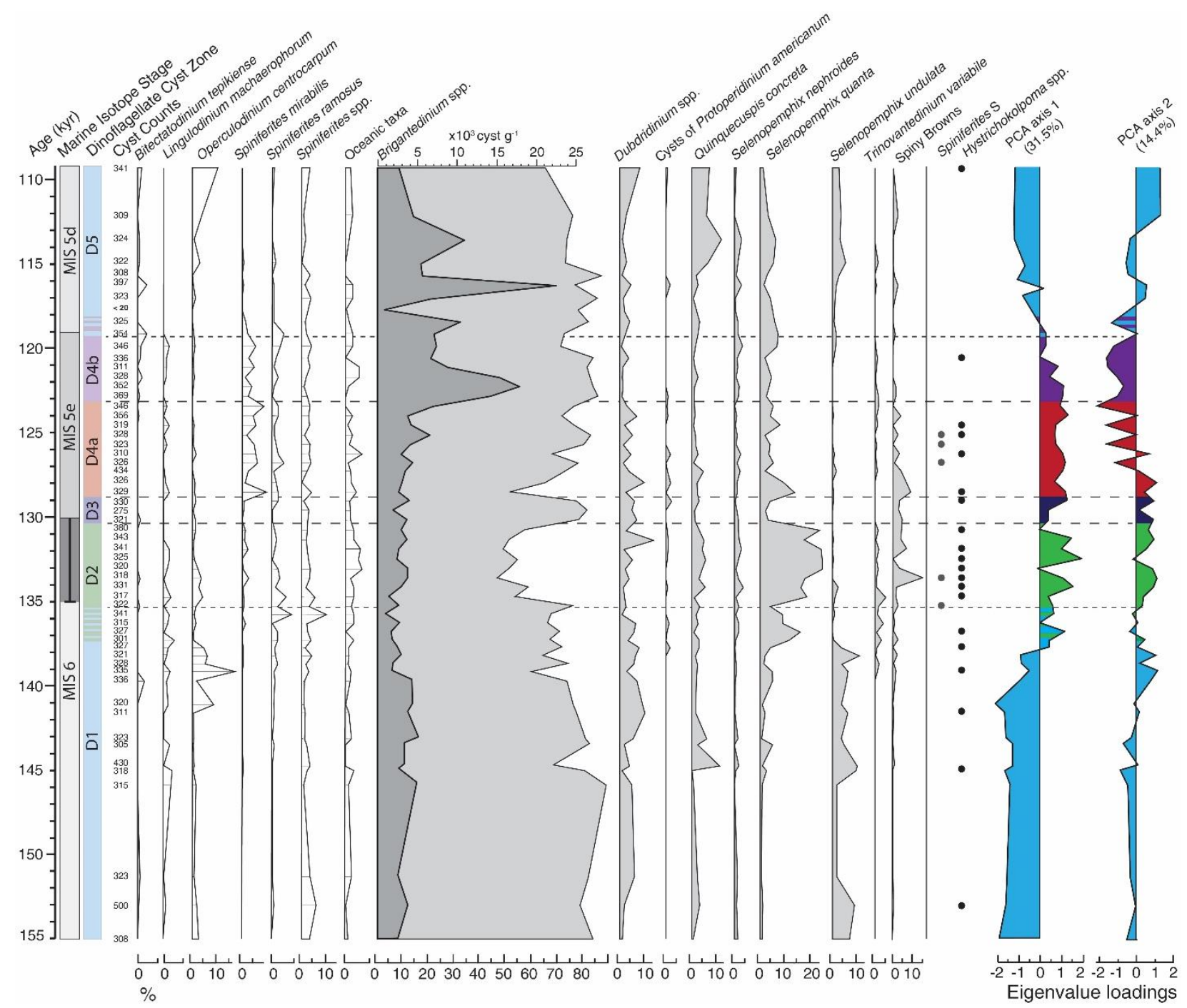

Figure 2. Relative abundances (\%) of selected dinoflagellate cyst taxa that contribute more than $1.5 \%$ in at least one cyst assemblage plotted downcore with the age. Marine Isotope Stages (MIS), color coordinated dinoflagellate cyst zones distinguished by dotted lines plotted across the diagram, and cyst counts are to the left; the disputed range of MIS 5e is highlighted in dark grey (see text). Cysts produced by autotrophic taxa are shown in white and cysts produced by heterotrophic dinoflagellates are shown in grey. The concentration of total Brigantedinium is shown juxtaposed on the \% plot in dark grey. Extinct taxa Hystrichokolpoma spp. and Spiniferites type S are shown by dots to indicate their presence in samples. To the right are sample scores from the principle component analysis (PCA). 


\subsection{Statistical Analyses and Quantitative Techniques}

Only taxa that contribute $1.5 \%$ in at least one assemblage were included in the statistical analyses. The diversity of the dinoflagellate cyst assemblages was calculated using species richness and the Shannon-Wiener index (SWI). The latter takes into consideration the number of species in each sample and how numerically similar each species is to each other in a measure of "evenness". When the abundances of each species are more unequal, SWI approaches zero.

Dinoflagellate cyst counts were transformed according to:

$$
\text { Value }=\log \left(\left(\left(\mathrm{n} / \mathrm{T}_{\mathrm{S}}\right) * 1000\right)+1\right)
$$

in order to increase the statistical weight of ecologically important species present in low abundances, where $n$ is the taxa count, $T_{s}$ is the total cyst count for the sample. The values represent $\log$ transformed relative abundances and are presented in per mil to avoid decimals while the +1 avoids undefined values in the absence of species. The resultant values of dinoflagellate cyst data are used in Detrended correspondence analysis (DCA) and Principle component analysis (PCA) performed using the free paleontological statistics software PAST [Hammer and Harper, 2001]. The length of the first DCA gradient was 1.07, which supports the use of the linear ordination method PCA to explore the main gradients responsible for the distribution of the species composition data [Lepš and Šmilauer, 2003].

Quantitative reconstruction of PP, SST, and SSS was performed on the dinoflagellate cyst assemblages using the modern analogue technique (MAT), a transfer function method based on similarities of assemblages in the modern and paleo record, using the software "R" (http://cran.rproject.org) and the script provided on the Geotop Supplementary material website in accordance with the procedure outlined in de Vernal et al. [2013]. Two transfer functions were attempted, the first with the entire established and calibrated Geotop database (1492 sites, 66 taxa) in the North 
Atlantic and North Pacific [e.g. de Vernal et al., 2001, 2005, 2013] and the second with the North Pacific database containing 287 sites calibrated by Radi and de Vernal [2008] and Pospelova et al., [2008]. Reconstructions were made using the three closest modern analogues for each sample. The threshold value (dT), defined from the mean distance minus standard deviation of randomly selected analogues in the database, was used to identify poor analogues. Assemblages with analogue distance less than dT/2 were identified as good, between dT/2 and dT acceptable, and a distance greater than $\mathrm{dT}$ poor, which are excluded from the reconstructions as a no analogue situation [e.g. de Vernal et al., 2001; 2005; 2013]. 


\section{Results}

\subsection{Palynomorph Total Concentrations, Abundances, and Ratios}

All analyzed samples from ODP Hole 893A contained organic-walled dinoflagellate cysts and other palynomorphs; bright-field photomicrographs of selected taxa are presented in Plates I, II, III, IV, and V. When the low count sample (UVic ID 2018-18) is excluded total counts range from 275 to 500 for cysts and from 138 to 434 for pollen and spore grains. Total cyst concentrations vary by an order of magnitude from $\sim 1350$ to $\sim 21,000$ cysts $\mathrm{g}^{-1}$, averaging 6352 cysts $\mathrm{g}^{-1}$ (Figure 3). The highest total cyst concentrations occur during the latter part of MIS 5e when the sediments are laminated. Cysts produced by heterotrophic taxa dominate the assemblages throughout the entire sequence, averaging $~ 5900$ cysts $\mathrm{g}^{-1}$ compared with $\sim 480$ cysts $\mathrm{g}^{-1}$ for autotrophic taxa. While the concentrations of cysts of autotrophic taxa are relatively low, they reach a maxima during MIS 5e, as reflected in the minimum of the heterotrophic to autotrophic cyst (H:A) ratio during this period (Figure 3).

The total concentration of total pollen and spores varies from $\sim 1500$ to 41,000 grains $\mathrm{g}^{-1}$

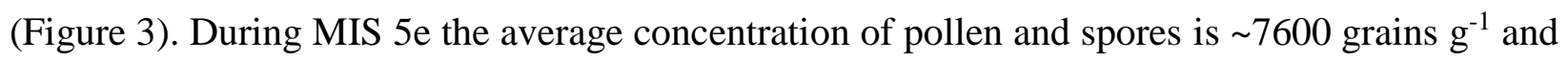

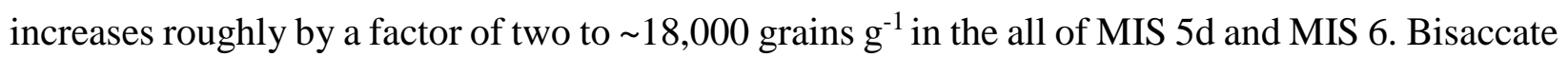
pollen, mostly produced by coniferous trees Pinus and Abies, make up the majority of the pollen counted (50-99\%), averaging $82 \%$ of the total pollen and spores. Non-bisaccate pollen such as Quercus and Asteraceae reach their maximum quantities during MIS 5e (Figure 3). A dramatic increase and maximum in the total concentrations of pollen and spores, especially in bisaccate pollen, occurs from $\sim 138$ to 134.5 kyr during the glacial-interglacial transition. 
Concentrations of foraminiferal organic linings (FOLs) are less abundant overall, but show a peak when concentrations of dinoflagellate cysts are also high (Figure 3). The maximum concentration of $\sim 500$ FOL $\mathrm{g}^{-1}$ occurs during MIS 5e. Heterotrophic dinoflagellate cysts and foraminiferal linings are indirect proxies of marine primary productivity as their living stages feed on primary producers, and thus their relative abundances reflect this availability of food [e.g. Pospelova et al., 2006; Bringué et al., 2013; Zonneveld et al., 2013]. 

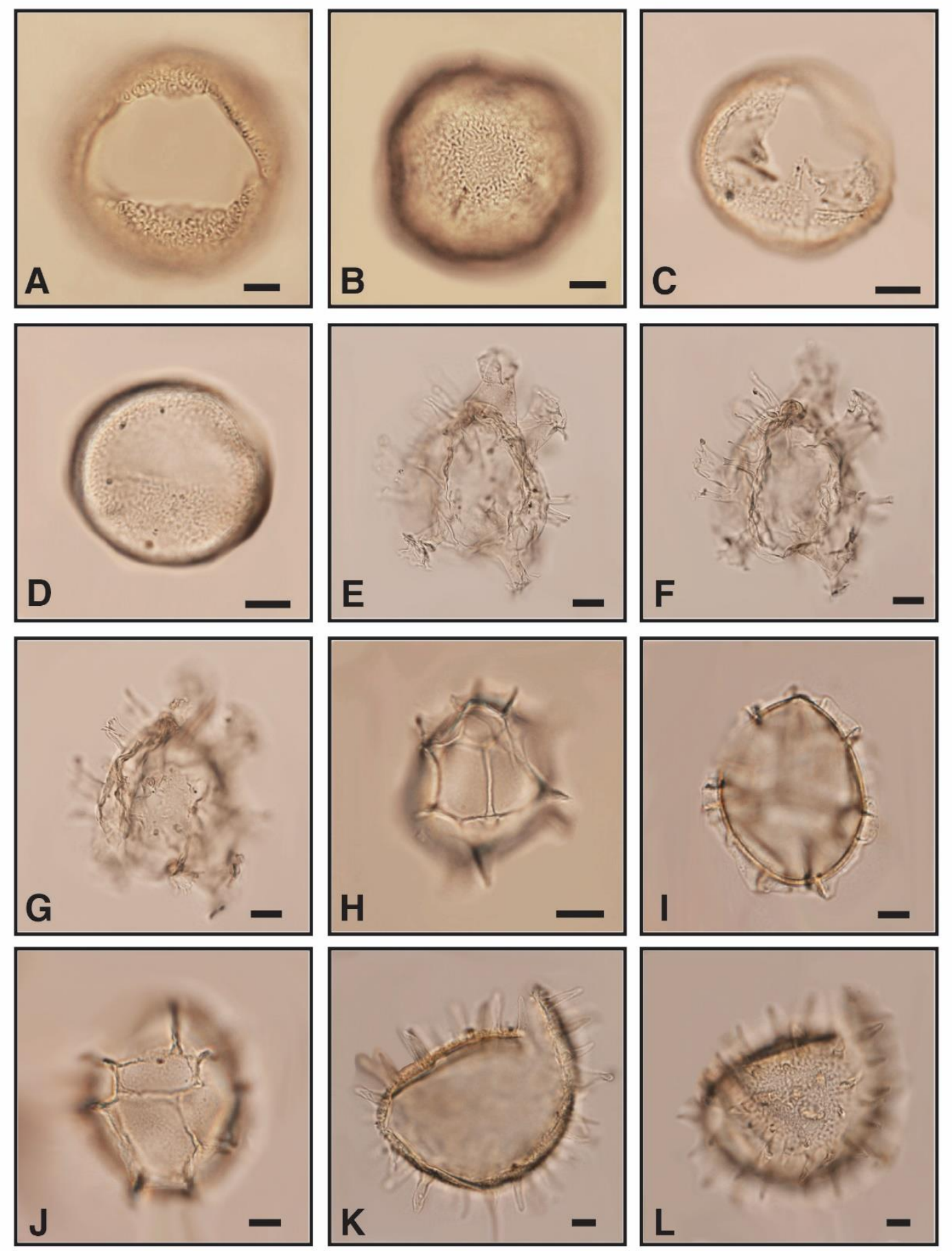

Plate I. Bright field photomicrographs of selected autotrophic dinoflagellate cysts. A-B, Bitectatodinium tepikiense, sample UVic 2018-2, sl. 1. C-D, Habibacysta tectata?, sample UVic 2018-32. sl. 1. EG, ?Hystrichokolpoma spp., sample UVIC 2018-32, sl. 1. H, Impagidinium aculeatum, sample UVic 201832, sl. 1. I-J, Impagidinium? paradoxum, sample UVic 2018-10, sl. 1. K-L, Lingulodinium machaerophorum, sample UVic 2018-42, sl. 1. Scale bars are $10 \mu \mathrm{m}$. 

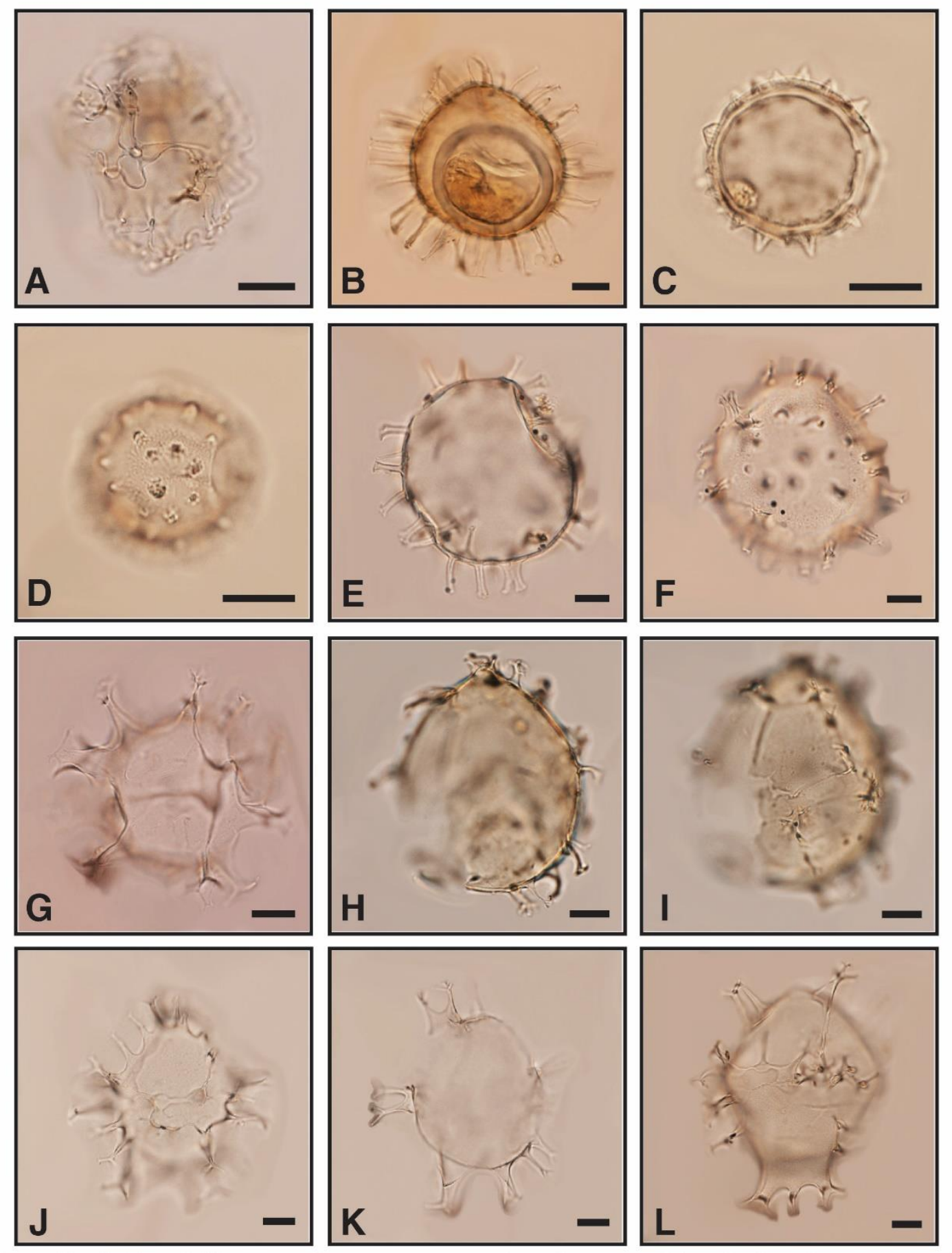

Plate II. Bright field photomicrographs of selected autotrophic dinoflagellate cysts. A, Nematosphaeropsis labyrinthus, sample UVic 2018-6, sl. 1. B, Operculodinium centrocarpum, sample UVic 2018-55, sl. 1. CD, Operculodinium janduchenei, sample UVic 2018-42, sl. 1. E-F, Polysphaeridium zoharyi, sample UVic 2018-34, sl. 1. G, Spiniferites spp., sample UVic 2018-39, sl. 1. H-I, Spiniferites bentorii, sample UVic 2018-21, sl. 1. J-K, Spiniferites hyperacanthus, sample UVic 2018-32, sl. 1. L, Spiniferites mirabilis, sample UVic 2018-11, sl. 1. Scale bars are $10 \mu \mathrm{m}$ 

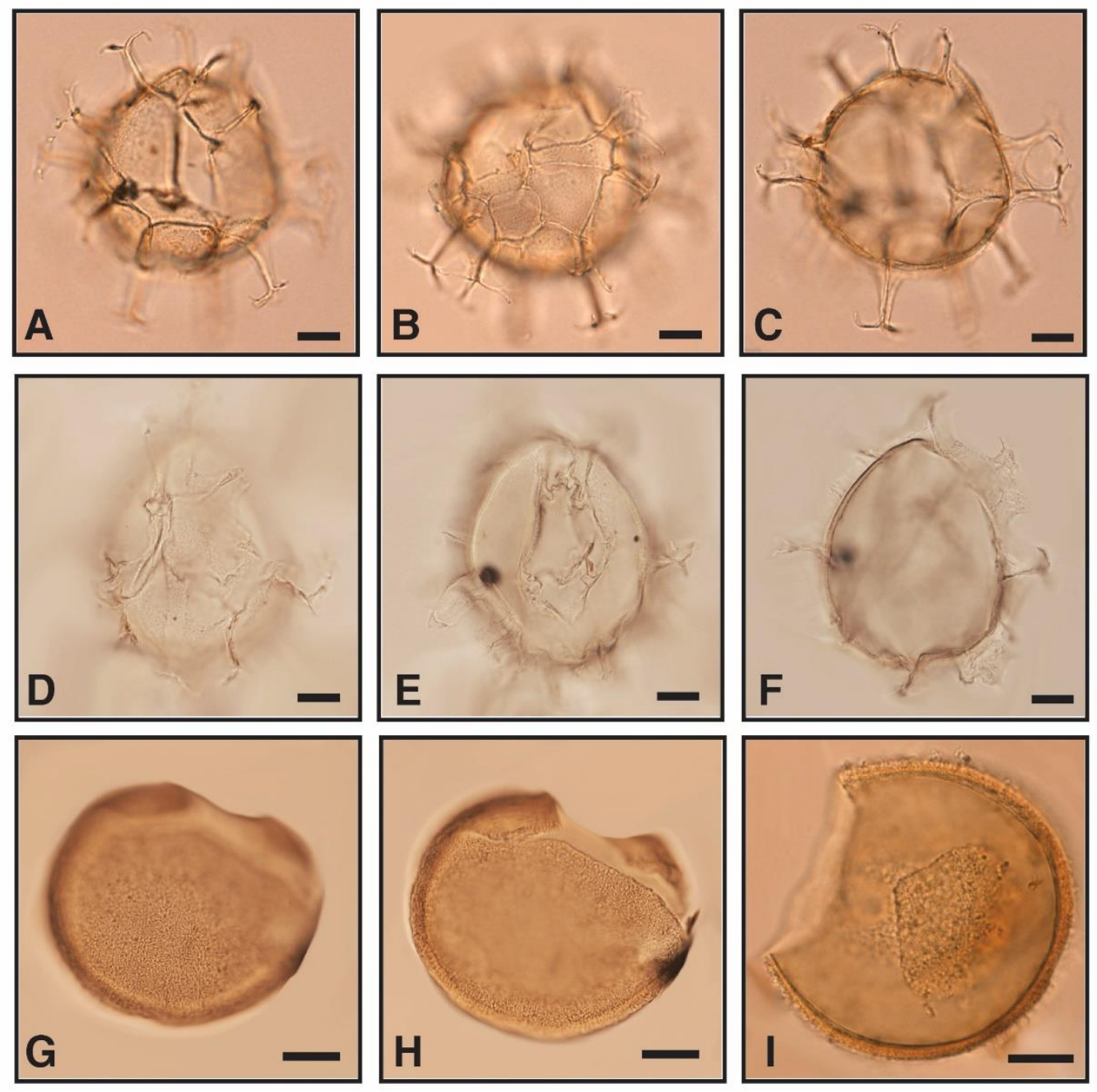

Plate III. Bright field photomicrographs of selected autotrophic dinoflagellate cysts. A-C, Spiniferites pachydermus, sample UVic 2018-21, sl. 1. D-F, Spiniferites type S, sample UVic 2018-23, sl. 1. G-I, Tectatodinium? pellitum, sample UVic 2018-42 sl. 1 and UVic 2018-2 sl. 1. Scale bars are $10 \mu \mathrm{m}$. 

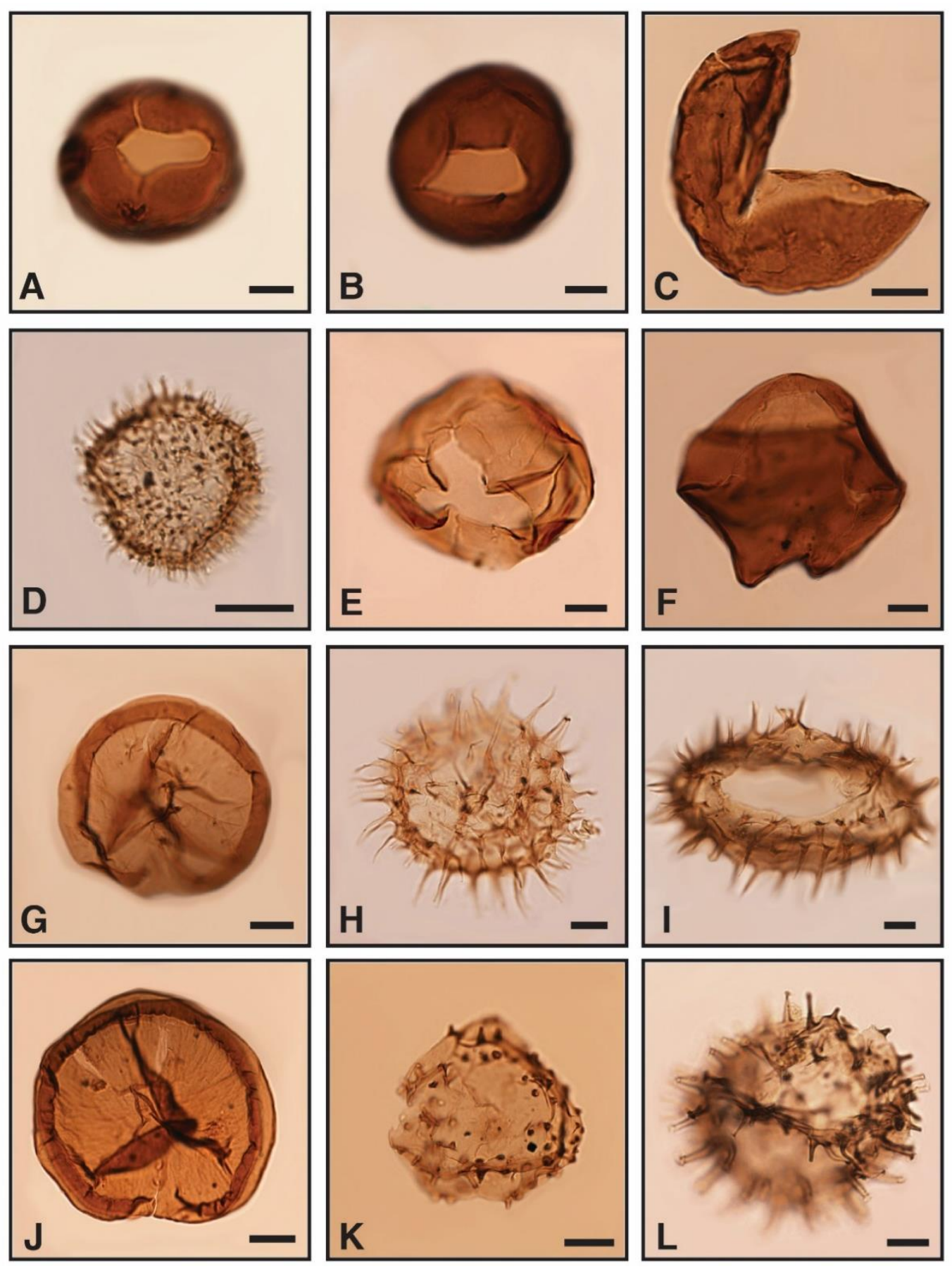

Plate IV. Bright field photomicrographs of selected heterotrophic dinoflagellate cysts. A, Brigantedinium cariacoense, sample UVic 2018-34, sl. 1. B, Brigantedinium simplex, sample UVic 2018-18, sl. 1. C, Dubridinium spp., sample UVic 2018-32, sl. 1. D, Echinidinium cf. delicatum, sample UVic 2018-40, sl. 1. E, Cyst of Protoperidinium americanum, sample UVic 2018-6, sl. 1. F, Quinquecuspis concreta, sample UVic 2018-36, sl. 1. G, Selenopemphix nephroides, sample UVic 2018-31, sl. 1. H-I, Selenopemphix quanta, sample UVic 2018-10 sl.1 and UVic 2018-40, sl.1. J, Selenopemphix undulata, sample UVic 201826, sl. 1. K, Trinovantedinium type S, sample UVic 2018-38, sl. 1. L, Trinovantedinium variabile, sample UVic 2018-37, sl. 1. Scale bars are $10 \mu \mathrm{m}$. 

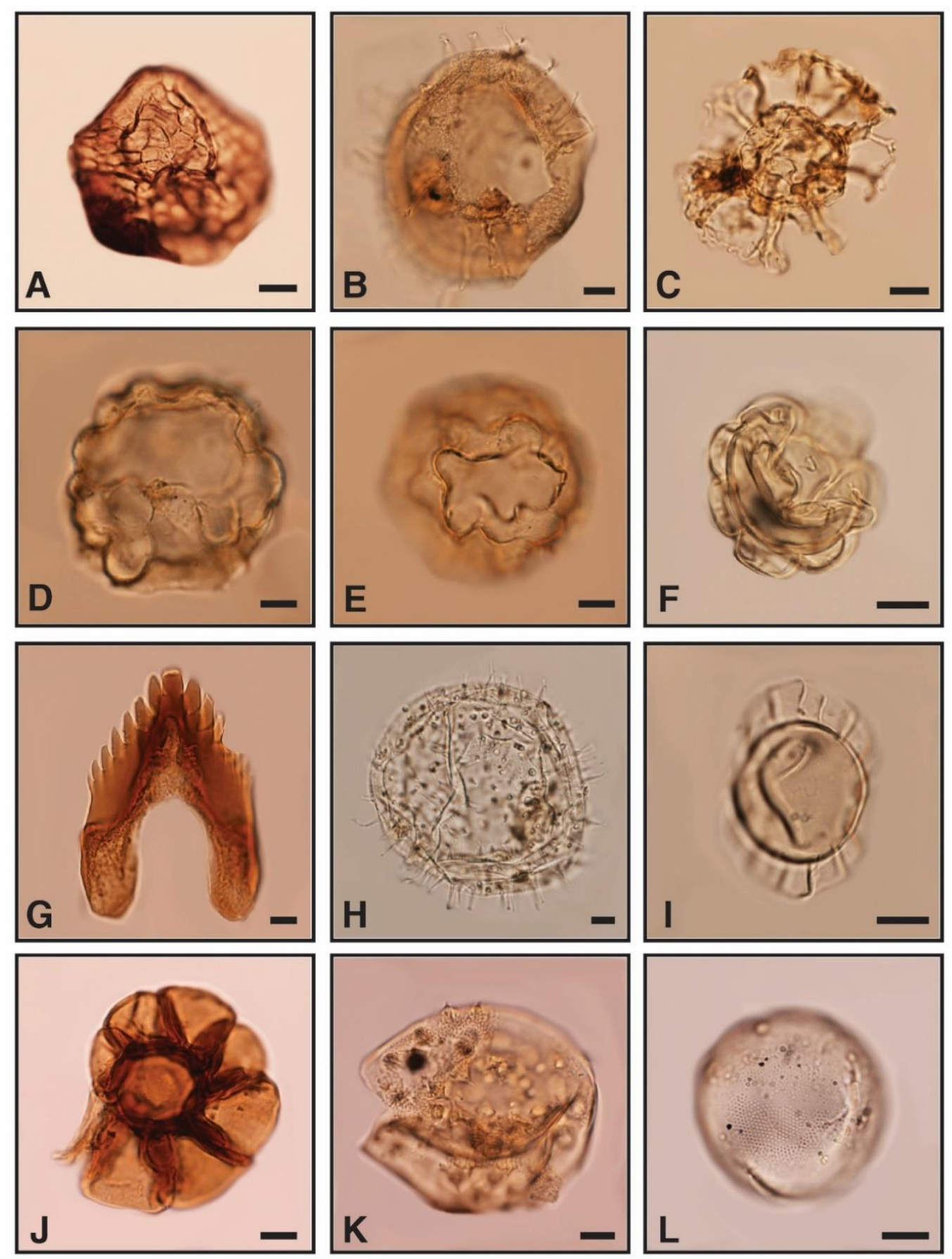

Plate V. Selected bright field photomicrographs of known and unknown palynomorphs. A, unknown palynomorph type P, UVic 2018-30, sl. 1. B, reworked extinct dinoflagellate cyst? type Y, sample UVic 2018-55, sl. 1. C, reworked extinct dinoflagellate cyst? type N, sample UVic 2018-53, sl. 2. DE, ?Globorotunda, sample UVic 2018-55, sl. 1. F, unknown palynomorph type Z, sample UVic 2018-13, sl. 1. G, Mandible, sample UVic 2018-6, sl. 1. H, Copepod egg, sample UVic 2018-3, sl. 1. I, Prasinophyte, sample UVic 2018-53, sl. 2. J, Foraminifera organic lining, sample UVic 2018-13, sl. 1. K, unknown palynomorph type C, sample UVic 2018-3, sl. 1. L, unknown palynomorph type D, sample UVic 2018-13, sl. 1. Scale bars are $10 \mu \mathrm{m}$. 


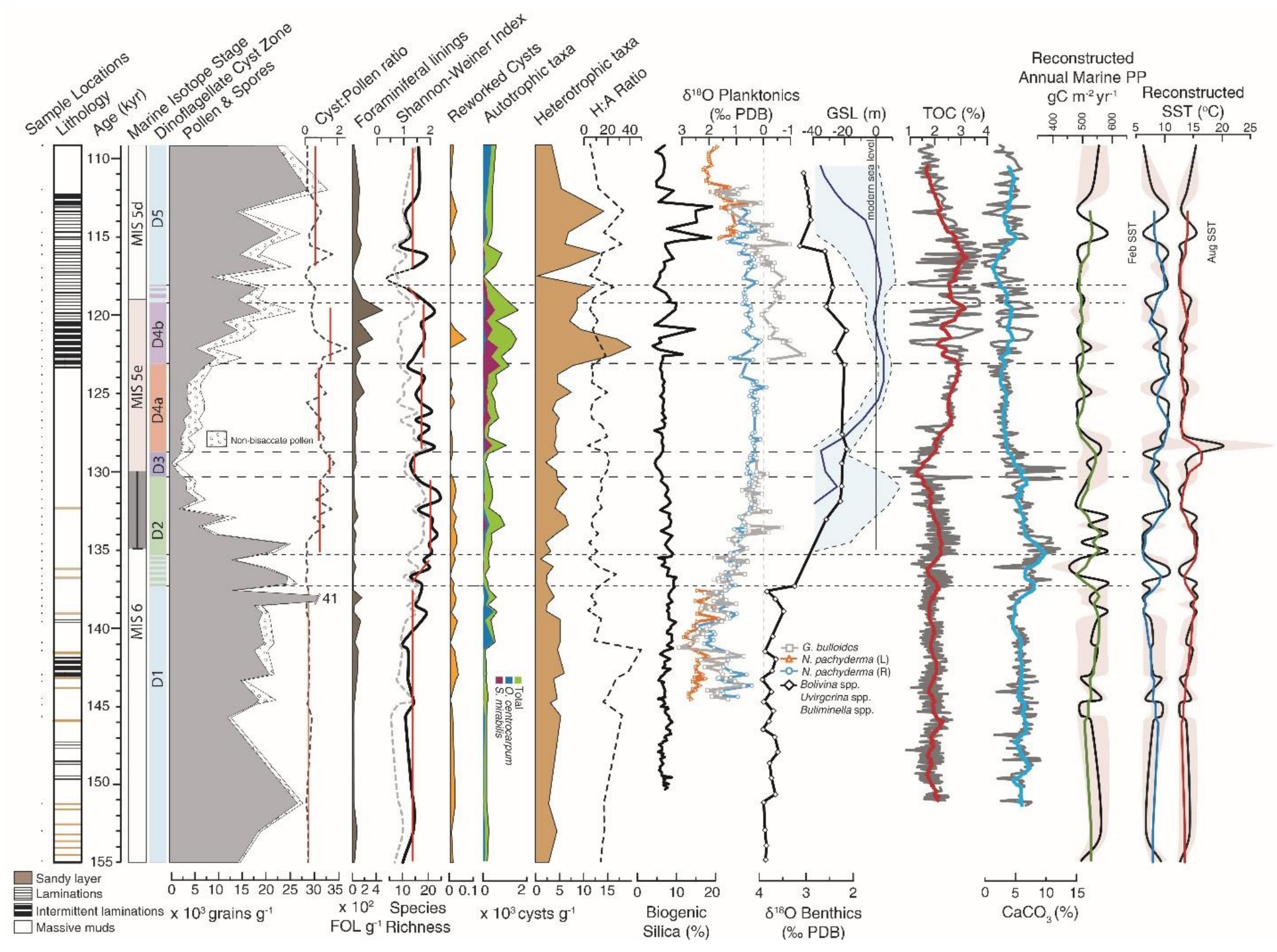




\subsection{Dinoflagellate Cyst Assemblages}

Forty dinoflagellate cyst taxa were identified in the studied sections of ODP Hole 893A (Table 2). When grouped, the species richness ranges from 9 to 24 , averaging 16 , while the SWI ranges from 0.5 to 1.8 , averaging 1.1 (Figure 3 ). Throughout the sequence, the assemblages are dominated by cysts produced by heterotrophic dinoflagellates, namely the round brown Protoperidinium cysts of Brigantedinium spp. that make up $40-86 \%$ of the sample assemblages, averaging $68 \%$. Other heterotrophic taxa that contribute a substantial proportion of the cyst assemblages include Spiny Brown cysts (0-14\%), Dubridinium spp. (0.6-13\%), Quinquecuspis concreta (0.3-12\%), Selenopemphix nephroides (0-3\%), Selenopemphix quanta (0.3-24\%), Selenopemphix undulata (0-10\%), Trinovantedinium variabile (0-4\%), and cysts of Protoperidinium americanum (0-2\%) (Figure 2). Cysts of the autotrophic taxa that contribute on average more than $1.5 \%$ to the assemblage include Spiniferites spp. (0-14\%), Spiniferites mirabilis (0-9\%), and Operculodinium centrocarpum sensu Wall and Dale [1966] (0-16\%), while Spiniferites ramosus (0-4\%), Bitectatodinium tepikiense (0-2\%), Lingulodinium machaerophorum (0-2\%), and oceanic taxa (0$2 \%$ ) rarely comprise more than $1.5 \%$ of the assemblages (Figure 2 ).

Pg. 23 Figure 3. Sample position is given next to the general lithostratigraphy of ODP Hole 893A. Total concentrations of pollen and spores, ratio of cysts to pollen/spores, total concentrations of foraminiferal linings, species richness (solid line with zonal avg. in red) and Shannon-Weiner Index (SWI) diversity measurements (dashed line), total concentrations of reworked cysts, cysts produced by autotrophic dinoflagellates with contribution of Operculodinium centrocarpum in blue and Spiniferites mirabilis in red, and cysts produced by heterotrophic dinoflagellates. The diagram also illustrates the downcore ratio of heterotrophic to autotrophic (H:A) cysts to the previously published ODP Hole 893A data of biogenic silica (\%) [Friddell et al., 2002], planktonic foraminifera $\delta^{18} \mathrm{O}$ [Friddell et al., 2002], benthic foraminifera $\delta^{18} \mathrm{O}$ [Kennett, 1995], a global sea level curve modified from Kopp et al., [2009], total organic carbon (TOC, \%) and percent calcium carbonate $\left(\mathrm{CaCO}_{3}, \%\right)$ with 10 point running averages [Gardner and Dartnell, 1995; Stein and Rack, 1995]. Cyst based quantitative reconstructions of annual primary productivity (PP) and August and February sea surface temperature (SST) are shown in black, colored lines indicate a 3 point running average and the grey borders indicate the confidence interval. 
Table 2. Taxonomic citation of dinoflagellate cysts used in this study

\begin{tabular}{|c|c|c|}
\hline Cyst Species (Paleontological Name) & $\begin{array}{l}\text { Dinoflagellate Theca Name or } \\
\text { Affinity (Biological Name) }\end{array}$ & Grouped with \\
\hline \multicolumn{3}{|l|}{ Autotrophic } \\
\hline Bitectatodinium tepikiense & Gonyaulax digitale & \\
\hline Habibacysta tectata? & unknown & \\
\hline Hystrichokolpoma? spp. & unknown & \\
\hline Impagidinium spp. & Gonyaulax sp. indet. & All Impagidinium spp. are grouped \\
\hline Impagidinium aculeatum & Gonyaulax sp. indet. & together into oceanic taxa \\
\hline Impagidinium paradoxum & Gonyaulax sp. indet. & \\
\hline Impagidinium plicatum & Gonyaulax sp. indet. & \\
\hline Impagidinium sphaericum & Gonyaulax sp. indet. & \\
\hline Lingulodinium machaerophorum & Lingulodinium polyedrum & \\
\hline Nematosphaeropsis labyrinthus & Gonyaulax spinifera complex & Grouped into oceanic taxa \\
\hline $\begin{array}{l}\text { Operculodinium centrocarpum sensu } \\
\text { Wall and Dale, } 1966\end{array}$ & Protoceratium reticulatum & $\begin{array}{l}\text { Includes } O \text {. centrocarpum var. short } \\
\text { processes. }\end{array}$ \\
\hline Operculodinium janduchenei & unknown & \\
\hline & Pentapharsodinium dalei & \\
\hline Polysphaeridium zoharyi & Pyrodinium bahamense & \\
\hline Spiniferites spp. & Gonyaulax sp. indet. & \\
\hline Spiniferites bentorii & Gonyaulax digitalis & \\
\hline Spiniferites bulloideus & Gonyaulax scrippsae & Grouped with Spiniferites spp. \\
\hline Spiniferites hyperacanthus & Gonyaulax spinifera complex & Grouped with Spiniferites mirabilis \\
\hline Spiniferites mirabilis & Gonyaulax spinifera & \\
\hline Spiniferites pachydermus? & Gonyaulax ellegaardiae & \\
\hline \multicolumn{3}{|l|}{ Spiniferites type $\mathrm{S}$} \\
\hline Spiniferites ramosus & Gonyaulax spinifera & \\
\hline Tectatodinium pellitum & Gonyaulax spinifera & \\
\hline \multicolumn{3}{|l|}{ Heterotrophic } \\
\hline Brigantedinium spp. & Protoperidiniaceae & \\
\hline Brigantedinium cariacoense & Protoperidinium avellanum & Grouped into Brigantedinium spp. \\
\hline Brigantedinium simplex & Protoperidinium conicoides & Grouped into Brigantedinium spp. \\
\hline Dubridinium spp. & Diplopsalid group & \\
\hline $\begin{array}{l}\text { Echinidinium spp. } \\
\text { Echinidinium delicatum }\end{array}$ & $\begin{array}{l}\text { Diplopsalid or Protoperidinoid } \\
\text { group }\end{array}$ & $\begin{array}{l}\text { All Echinidinium spp. were grouped } \\
\text { into Spiny Browns }\end{array}$ \\
\hline \multicolumn{3}{|l|}{ Echinidinium granulatum } \\
\hline Globorotunda? spp. & unknown & \\
\hline Lejeunecysta spp. & Protoperidinium sp. & $\begin{array}{l}\text { Grouped with Quinquecuspis } \\
\text { concreta }\end{array}$ \\
\hline - & Protoperidinium americanum & \\
\hline Quinquecuspis concreta & Protoperidinium leonis & \\
\hline Selenopemphix nephroides & Protoperidinium subinerme & \\
\hline Selenopemphix quanta & Protoperidinium conicum & \\
\hline Selenopemphix undulata & Protoperidinium? biconicum & \\
\hline Trinovantedinium type $\mathrm{S}$ & & \\
\hline Trinovantedinium variabile & Protoperidinium sp. indet. & \\
\hline Votadinium calvum & Protoperidinium oblongum & \\
\hline Spiny brown cysts & $\begin{array}{l}\text { ?Diplopsalid or Protoperidinoid } \\
\text { group }\end{array}$ & \\
\hline
\end{tabular}

${ }^{\mathrm{a}}$ Thecal equivalents are taken from Head [1996], Head et al,. [2001], Zonneveld and Pospelova [2015] 
The first two components of the PCA analysis explain $31.5 \%(\mathrm{PC} 1)$ and $14.4 \%$ (PC2) of the variance in the sample cyst data, respectively (Figure 4). Samples that are more similar to each other are plotted closer on the ordination diagrams. The scores of PC1 are driven by Spiniferites mirabilis (positive) and Selenopemphix undulata (negative), of which these taxa are associated with warmer and colder nutrient rich waters, respectively, in the eastern Pacific [Pospelova et al., 2008; Verleye et al., 2011]. Based on the sample scores from the PCA axes, dinoflagellate cyst assemblage compositions, and total concentration data, five primary dinoflagellate cyst zones (D1D5) are recognized with D4 split into subzones a and b (Figures 2 and 3). A summary for the parameters of the dinoflagellate cyst assemblages are broken down by cyst zone in Table 3 .

Table 3. Summary of dinoflagellate cyst zone average Principle Component (PC) axis values, cyst concentrations (conc.), ratio, species richness and Shannon-Weiner Index (SWI), as well the general sea level state or trend.

\begin{tabular}{|c|c|c|c|c|c|c|}
\hline Marine Isotope Stage & MIS 6 & \multicolumn{4}{|c|}{ MIS 5e } & MIS 5d \\
\hline Dinoflagellate cyst zone & D1 & D2 & D3 & D4a & D4b & D5 \\
\hline PC 1 & -1.32 & 0.96 & 0.29 & 0.99 & 0.66 & -0.82 \\
\hline $\mathrm{PC} 2$ & 0.034 & 0.58 & 0.61 & -0.31 & -0.98 & 0.32 \\
\hline Conc. of heterotrophic cysts (cysts $\mathrm{g}^{-1}$ ) & 3,935 & 4,376 & 3,736 & 5,002 & 13,002 & 8,111 \\
\hline Conc. of autotrophic cysts (cysts $\mathrm{g}^{-1}$ ) & 268 & 430 & 179 & 591 & 1,144 & 477 \\
\hline Ratio of heterotrophs to autotrophs & 20 & 11 & 21 & 11 & 12 & 19 \\
\hline Ratio of cysts to pollen/spores & 0.23 & 0.72 & 1.47 & 0.92 & 1.08 & 0.56 \\
\hline Species richness/SWI & $13 / 0.96$ & $20 / 1.54$ & $13 / 0.92$ & $17 / 1.19$ & $17 / 0.91$ & $13 / 1.01$ \\
\hline Global Sea level trend [Kopp et al., 2009] & low & $\uparrow$ & 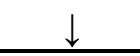 & $\uparrow$ & high & 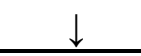 \\
\hline
\end{tabular}




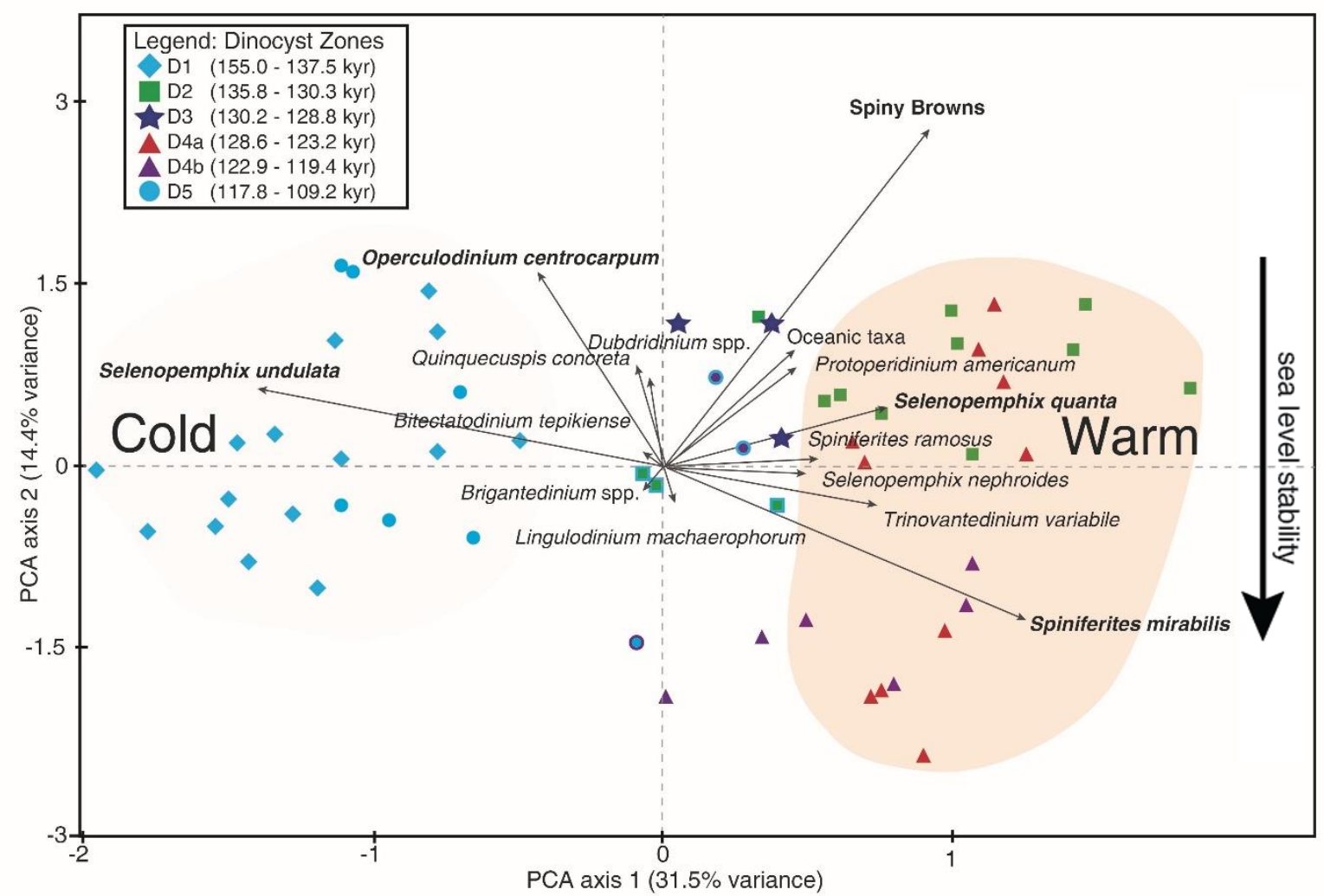

Figure 4. Results of principle components analysis (PCA) with biplot of dinoflagellate cyst taxa (black arrows) and ordination of samples with the color and shape associated with their dinoflagellate cyst zone; bordered shapes belong to transitional samples. General inferred conditions are labelled by axis; the first PC axis represents $33.4 \%$ of the variance and is associated with SST and the second PC axis represents $13.5 \%$ and is partially explained by sea level stability.

\subsubsection{Zone D1 (Samples from 155.0 - $137.5 \mathrm{kyr}$. Transitional period from 137.2 - $136.1 \mathrm{kyr}$ )}

This zone is characterized by all negative PC1 values and fluctuating PC2 values, especially in the upper and transitional section (Figure 2). Zone D1 cyst assemblages have the lowest average zonal species richness ( 13), a SWI average of 0.96, and are characterized by the highest proportions of Selenopemphix undulata (1.5-10.3\%) and the lowest zonal average abundance and concentration of Spiniferites mirabilis $\left(0.15 \%, 5.7\right.$ cysts $\left.\mathrm{g}^{-1}\right)$. The zone is marked by maximum of Operculodinium centrocarpum $(\sim 16.5 \%)$ before the transitional period from 137.2-136.1 kyr. The 
cyst to pollen ratio zonal average $(0.22)$ is at a very stable minimum throughout the zone, while the $\mathrm{H}$ :A ratio reaches a maximum (50.3) 143-141.5 kyr (Figure 3). This zone can be matched to MIS 6 and the transitional part of the zone matches the beginning of Termination II.

\subsubsection{Zone D2 (Samples from 135.8 - $130.3 \mathrm{kyr}$ )}

Zone D2 has the highest average species richness ( 20), the average SWI of 1.54 indicates the greatest species evenness, and the first overall increase in the cyst to pollen ratio occurs from 0.23 up to 1.67 (Figure 3). The average relative abundance of Selenopemphix quanta increases dramatically $(\sim 17.5 \%)$ and drops the proportion of Brigantedinium spp. to its minimum relative abundance (40.7\%) as a result (Figure 2). Consistent values of Spiniferites mirabilis appear, but still average $<1 \%$ of the assemblage while maximum zonal averages of Lingulodinium machaerophorum $(0.37 \%)$ and oceanic taxa $(1.38 \%)$ occur. Reworked cysts are consistently present in zone D2 (Figure 3). The most commonly encountered extinct dinoflagellate taxon is Hystrichokolpoma spp. okinawa? [Matsuoka, 1979], which is described in the lower Pleistocene

(Plate I). A previously unknown Spiniferites type S. (Plate III) is also recorded in this zone. The zone has positive PC1 values and positive PC2 values, and corresponds to the disputed extension of MIS 5e observed by Friddell et al., [2002].

\subsubsection{Zone D3 (Samples from 130.2 - $128.8 \mathrm{kyr}$ )}

In this relatively short zone the average species richness of the cyst assemblages drops from 20 to 13 and a lower SWI indicates a more uneven species distribution (Figure 3). Cysts of autotrophic dinoflagellates comprise $<0.05 \%$ including the disappearance of Lingulodinium machaerophorum and a drop in the zonal average of Spiniferites mirabilis to less than half the previous zone's concentration (Figure 3). Cysts of Brigantedinium spp. dominate cyst assemblages in the interval 
( $80 \%)$ (Figure 2), but the zone has a low overall total concentration of dinoflagellate cysts $\left(\sim 2,000-4,800\right.$ total cysts $\left.\mathrm{g}^{-1}\right)$ and minimum pollen and spore concentration of $1,523{\text { grains } \mathrm{g}^{-1}}^{-1}$ (Figure 3). Both PC1 and PC2 are positive, but PC1 values are subdued compared to D2 (Figure 2).

\subsubsection{Zone D4: Subzone 4a (Samples from 128.6 - 122.9 kyr), Subzone 4b (Samples from 122.8 - $119.8 \mathrm{kyr}$. Transitional period from 119.6 - $118.1 \mathrm{kyr}$ )}

As a whole, zone D4 is established based on stable positive PC1 values and negative PC2 values, the high concentrations and relative abundance of Spiniferites mirabilis, S. ramosus, and, $B$. tepikiense, a high species richness, and a relatively high cyst to pollen ratio. Of the pollen enumerated, the greatest proportion of non-bisaccate pollen occurs in D4. The zone matches very well with MIS 5e.

Subzone $4 \mathrm{a}$ is characterized by the highest zonal abundance of Spiniferites mirabilis $(\sim 1.2-9.5 \%)$ (Figure 2). PC2 values fluctuate in an overall increasingly negative trend to a minimum at the D4a/b boundary (Figure 2). Concentrations of cysts produced by autotrophic and heterotrophic dinoflagellates increase drastically in subzone $4 \mathrm{~b}$ to their maximum values of 1,533 cysts $\mathrm{g}^{-1}$ and 19,993 cysts $\mathrm{g}^{-1}$, respectively. Subzone $4 \mathrm{~b}$ also corresponds to the highest concentrations of FOL (501 FOL g ${ }^{-1}$ ) and to the beginning of the extended laminated section in the core (Figure 3). Even though the total cyst concentrations increases (Figure 3), Brigantedinium spp. remains relatively dominant (65-82\%), and the PCA based on relative abundance plots both subzones with an overall positive PC1 and a negative PC2 (Figure 2). The transition out of subzone $4 \mathrm{~b}$ is characterized by the reappearance of Selenopemphix undulata and simultaneous decline of 
Spiniferites mirabilis abundances as the overall assemblage diversity decreases (Figures 2 and 3). Reworked cysts reach a maximum of $\sim 113$ cysts $\mathrm{g}^{-1} \sim 121.5 \mathrm{kyr}$ in subzone $4 \mathrm{~b}$.

\subsubsection{Zone D5 (Samples from 117.8 - 109.2 kyr)}

Entering zone D5 the PC1 values become negative again with fluctuating PC2 values (Figure 2). The average total concentration of autotrophic taxa decreases from 1,144 cysts g $^{-1}$ to 476 cysts $^{-1}$

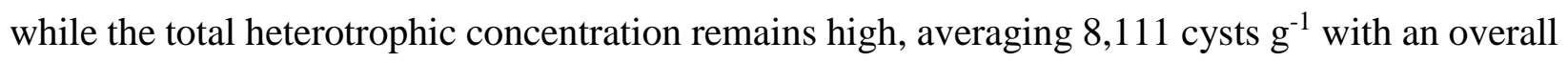
decrease $\sim 115 \mathrm{kyr}$ when the laminated section is replaced by massive muds (Figure 3 ). The zone is characterized by a maximum abundance of Quinquecuspis concreta $(\sim 11.7 \%)$ and Selenopemphix undulata comprises on average $2.6 \%$ of the assemblage. The average species richness of the assemblage drops to 13 and the cyst to pollen ratio declines to an average of 0.56 , but does not return to the minimum ratio (0.11) set by zone D1 (Figure 3).

\subsection{Quantitative Reconstructions}

The reconstruction of SST, SSS, and PP was attempted using the dinoflagellate assemblages and the best modern analogue technique (MAT). For the first MAT trial with the global database of 1492 sites, closest analogues returned with modern sites from northern Greenland and the Barents Sea, effectively reconstructing SST below $5^{\circ} \mathrm{C}$ in the summer and $>3$ months of sea ice in MIS 6 and $5 \mathrm{~d}$ in the $\mathrm{SBB}$, conditions very unrealistic for southern California. The trial also returned five "no-analogues" and is not reported on any further. The second MAT trial with only North Pacific sites did a better job of reconstruction, and did not return any "no analogue" situations, but none of the sites selected as best analogues were south of Sacramento, CA $\left(39^{\circ} \mathrm{N}\right)$ and the most northern analogue is off the coast of Vancouver Island, B.C $\left(49^{\circ} \mathrm{N}\right)$. The average reconstructed SST for the month of August during the extent of MIS 5e $(\sim 130-119 \mathrm{kyr})$ is $13.92^{\circ} \mathrm{C}$ and the average for MIS 
$6(\sim 155-135 \mathrm{kyr})$ is $14.09^{\circ} \mathrm{C}$. The most supportive piece of the reconstruction for a warmer interglacial is the maximum August and February SST, which peaks in subzone $4 \mathrm{a}$ at $20.3^{\circ} \mathrm{C}$ and $10.6^{\circ} \mathrm{C}$, respectively (Figure 3). Seasonal SSS reconstructions ranged from 19 to $33 \mathrm{psu}$. Annual PP reconstructions range from 456 to $586 \mathrm{gC} \mathrm{m}^{-2} \mathrm{yr}^{-1}$, with the greatest variability during the transition from Zone D1 to D2 (Figure 3). 


\section{Discussion}

This work demonstrates that over Termination II and the LIG dinoflagellate cysts show a high sensitivity to hydrological and climatic changes on a sub-millennial scale in the SBB. The qualitative assessment of cyst assemblages indicates a late MIS 5e increase in PP and a two-step SST warming phase coupled with deglaciation of MIS 6 is punctuated by a brief cooling event before reaching peak SST in MIS5e (Figures 2 and 3). Successful quantitative reconstructions of PP and SST using the MAT are the first in the SBB, and are reasonably agreeable with the qualitative assessments done with the dinoflagellate cyst assemblage compositions and sedimentary proxies (Figure 3). Changes in the SBB surface waters associated with Termination II appeared to be synchronous with the terrestrial turnover [Heusser, 2000; Friddell et al., 2002] but precede the benthic $\delta^{18} \mathrm{O}$ signal [Kennett, 1995] and major changes in insolation [Berger, 1978] and global sea level [e.g. Kopp et al., 2009]. The latitudinal relationship between oceanicatmospheric circulations can also be assessed with the use of other ODP Sites with alkenone and microfossil proxies along the California margin (Figure 5A). By comparing the previously published dinoflagellate cyst records from Termination I [Pospelova et al., 2006, 2015] with Termination II [this study] in the SBB we infer some similarities and differences in sea surface conditions during these two interglacials. 

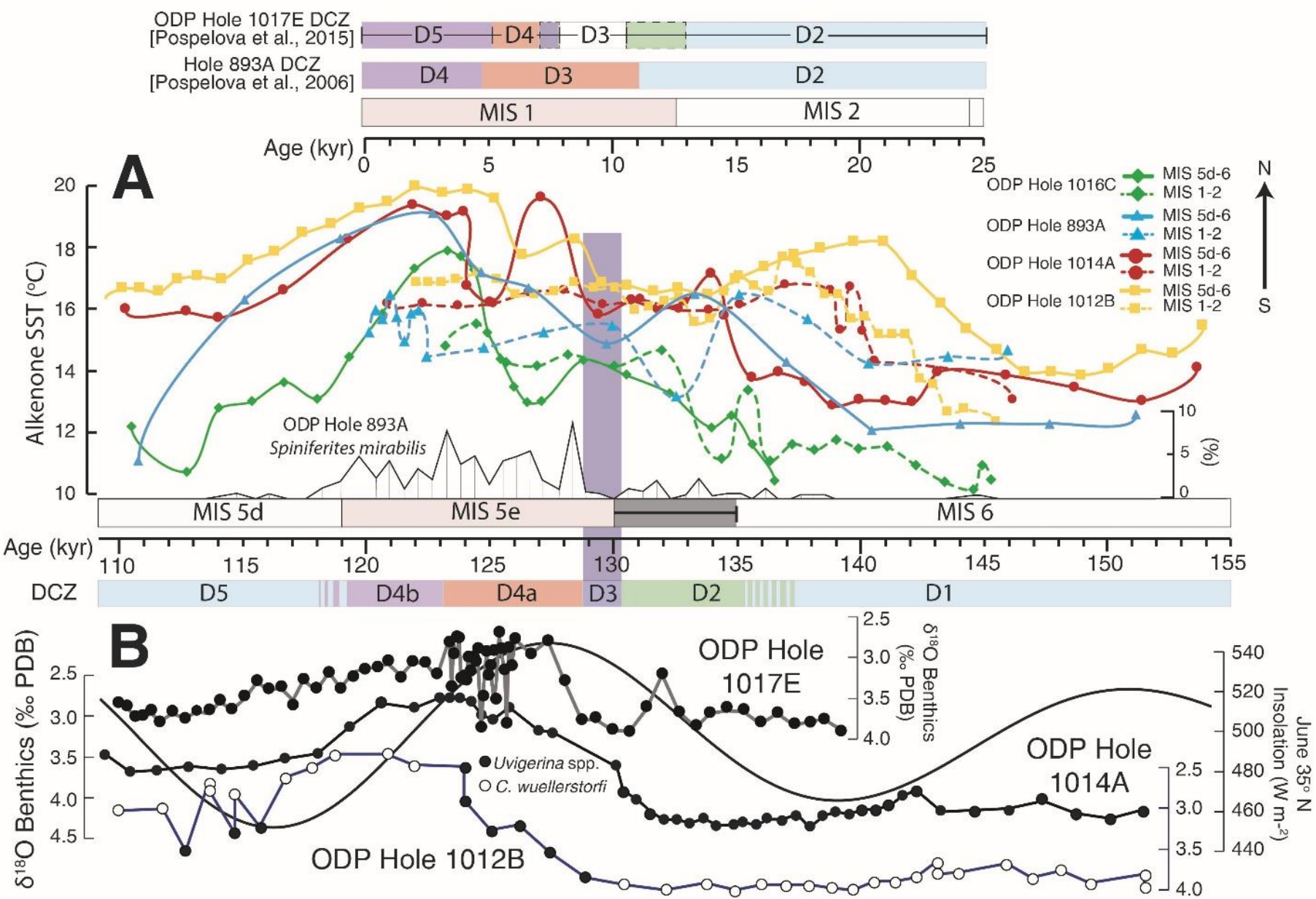

Figure 5. A) Previously published alkenone reconstructed SST values from ODP Holes 1016C and 1014A [Yamamoto et al., 2007], 893A [Herbert et al., 1995], and 1012B [Herbert et al., 2001] on the California margin (see Figure 1). Solid lines represent records from MIS 6 and 5 and dashed lines represent records from MIS 2 and 1. Dinoflagellate cyst zones (DCZ) from ODP Hole 893A [Pospelova et al., 2006] and ODP Hole 1017E [Pospelova et al., 2015] are coloured to represent similarities in assemblage interpretation with this study and are plotted above in correspondence to the ages of MIS 2 and 1, while the DCZ and relative abundance (\%) of thermophyllic Spiniferites mirabilis (this study) are plotted below along the MIS 6 and 5 timescale. B) MIS 6 and 5 benthic foraminifera $\delta^{18} \mathrm{O}$ records from ODP Holes 1017E [Kennett et al., 2000], 1014A [Hendy and Kennett, 2000], and 1012B [Andreasen et al., 2000] with the summer insolation curve [Berger 1978] plotted for reference. 


\subsection{Climatic and Hydrological Events}

Dinoflagellate cyst zone D1 corresponds to MIS 6, D2 to Termination II and the beginning of MIS 5e, D3 to a cooling period within MIS 5e, D4a and D4b to the MIS 5e climatic optimum, and D5 to MIS 5d. Along with the dinoflagellate cyst assemblages, ratios, and quantitative reconstruction, supporting alkenone reconstructed SST [Herbert et al., 1995], benthic and planktonic foraminifera $\delta^{18} \mathrm{O}$ [Kennett, 1995; Friddell et al., 2002], pollen [Heusser, 2000; Friddell et al., 2002], and geochemical proxies [Gardner and Dartnell, 1995; Stein and Rack, 1995; Friddell et al., 2002], were used to distinguish the climatic and hydrological evolution across the glacial-interglacial period in the SBB.

\subsubsection{MIS 6 and the Termination II Glacial-interglacial transition}

The later part of MIS 6 is documented in the analyzed section, and from 155-141 kyr where zone D1 shows low PC1 values the dinoflagellate assemblages have a low species richness and are dominated by cysts produced by heterotrophic dinoflagellates (Figures 2 and 3). The zone also has a low stable cyst to pollen ratio and a higher ratio of $\delta^{18} \mathrm{O}$ in the foraminifer records, which all point towards characteristic glacial conditions of lower SSTs and subdued PP in the SBB. This is in contrast to the MAT PP reconstruction. In the upper part of zone D1 141-138 kyr, an increase in the autotrophic cyst concentrations, caused mainly by an increase of Operculodinium centrocarpum, a species associated with unstable upper water masses at the coastal/oceanic boundary [Dale et al., 2002; Pospelova et al., 2008; Price et al., 2013], and coincides with increasing PC1 values (Figure 2) and maximum December insolation [Berger, 1978]. This species is interpreted to increase as a proxy for impending change in the marine realm of the SBB and is supported by a synchronous increase in the reconstructed alkenone SST and three consecutively lower benthic $\delta^{18} \mathrm{O}$ values from the previous MIS 6 average (Figures 3 and 5). In the terrestrial 
realm a similar disturbance is seen in the coastal SBB vegetation $\sim 140 \mathrm{kyr}$; Juniper pollen significantly decreases at this time, and as it thrives in cool wet conditions the shift is seen to indicate a continental warming and drying prior to Termination II [Heusser, 2000].

Unstable conditions prevail transitioning from zone D1 to D2 when abundances of Pinus pollen, a successional species associated with climatic turnover, show massive peaks in the SBB records [this study; Heusser and Sirocko, 1997; Friddell et al., 2002]. An overall minimum in the dinoflagellate cyst concentrations, the absence of Selenopemphix undulata, a minimum in concentrations of FOLs and $\mathrm{CaCO}_{3}$ abundances (Figures 2 and 3), and an overall low sea level [Kopp et al., 2009] suggest that the influence of the colder waters of the California Current on the SBB has been disrupted, and circulation in the basin conducive to upwelling and a higher nutrient supply is rather limited. A potential decrease in seasonality due to intermediate winter and summer insolation forcing may also contribute to the higher February, but lower August SSTs, as suggested by the quantitative reconstructions (Figure 3).

Entering zone D2 the species richness has a major increase and concentrations of autotrophic and heterotrophic dinoflagellate cysts rebound (Figure 3). The appearance of higher abundances of oceanic taxa in this zone suggests greater marine influences. The noticeable increase in the abundances of Spiniferites mirabilis occur in this zone and can be interpreted as greater influences of warm water in the SBB. Oak (Quercus) pollen abundance also rise in this interval indicating that the terrestrial warming signal is also firmly established at this point in Termination II [Friddell et al., 2002]. Alkenone values in the SBB and to the south at Hole 1014A both show initial SST peaks up to $15-16^{\circ} \mathrm{C} \sim 133 \mathrm{kyr}$ (Figure 5A) [Herbert et al., 1995; Yamamoto et al., 2007], and the first rapid rise $\left(\sim 20 \mathrm{~m} \mathrm{kyr}^{-1}\right)$ of sea level at this time [Kopp et al., 2009] initiated by the previous several thousand years of continental warming. The sea level rise would 
open up the Santa Barbara Channel to a greater influence of warmer waters of the California Countercurrent. The benthic $\delta^{18} \mathrm{O}$ record at Point Conception (ODP Hole 1017E, north of the SBB) shows the isotopic lightening associated with this sea level event (Figure 5B) [Kennett et al., 2000]. While SSTs probably warmed in this interval, sea level was not at modern day levels and the bottom waters remain relatively oxygenated based on the lack of laminations, thus upwelling associated PP may not have increased significantly during Termination II, despite the quantitative reconstruction. A replacement of the upwelling associated Brigantedinium spp. with higher abundances of Selenopemphix quanta and Spiny brown cysts (Figure 2) may support a change in the hydrology or other environmental factor. Maximum abundances of Lingulodinium machaerophorum, associated with "relaxed upwelling" intervals (August to January) when surface waters become warm and stratified [e.g. Bringué et al., 2013], also occurs in this zone.

\subsubsection{MIS 5e}

Zone D3 includes only three samples that are statistically different from the rest of MIS 5e, but suggest the warm conditions of zone D2 do not last long (up to $7 \mathrm{kyr}$ ). The zone is characterized by cooler SSTs, low dinoflagellate diversity, and a Brigantedinium spp. (>75\%) dominated assemblage. A few warm-water S. mirabilis and low concentrations of any autotrophic cysts were reported for this time (Figures 2 and 3). The zone coincides with a decrease in the relative abundance of oceanic taxa, a single point drop in SST in the lower resolution alkenone record from ODP Hole $893 \mathrm{~A}$ and 1014 , and the benthic $\delta^{18} \mathrm{O}$ record from ODP Hole 1017E returns to isotopically heavier values (Figure 4) that are consistent with a sea-level reversal or still-stand [Siddall et al., 2006; Kopp et al., 2009]. Pollen records in the SBB also show a brief cooling 
through a decrease in the oak pollen abundances [Friddell et al., 2002]. The associated change in PP is a bit more difficult to assign, as overall dinoflagellate cyst concentrations and \% TOC are at a low, but $\mathrm{CaCO}_{3} \%$ shows a peak and the cyst to pollen ratio is at a high. The quantitative reconstruction suggests an increased PP, but the uncertainty is the greatest in this zone (Figure 4).

The cooling episode in the dinoflagellate cyst record associated with Zone D3 is short ( 1-2 kyr), and the cyst assemblages are characterized by a positive PC1 and increasing PC2, consistent with maximum summer insolation [Berger, 1978] and the second rise in sea level described by Siddall et al., [2006] and Kopp et al., [2009]. Maximum SST may have been reached in this interval, as the relative abundance of $S$. mirabilis reaches a maximum and the reconstructed August SST reaches its peak early in zone D4a (Figures 2 and 3) and there is no evidence of increased upwelling. The first sign of another hydrological change occurs $\sim 125 \mathrm{kyr}$ when sea level has reached a maximum; an increase in the total concentration of heterotrophic cysts coincides with an increase in FOLs, increase in the H:A ratio, and the reconstructed February SST shows a drop consistent with cooler waters being brought to the surface during active upwelling. These upwelling influenced conditions appear to stabilize as sea level stabilizes in D4b and conditions in SBB become similar to modern day, including the deposition of laminated sediments. The diversity of dinoflagellate cysts increases, but the evenness is low as cysts of Brigantedinium spp. dominate the zone, suggesting enhanced upwelling conditions. The SST remains high overall, as S. mirabilis is still present in the assemblages, and it is supported by the alkenone records along the entire California margin that reconstruct a maximum SST $\sim 17-20^{\circ} \mathrm{C}$ (Figure 5A). High SSTs and strengthened upwelling during the latest part of MIS 5e appeared to be similar to modern day conditions in the basin, and it is supported by the SST and PP dinoflagellate cyst based quantitative reconstructed values. The separation of the $\delta^{18} \mathrm{O}$ planktonic foraminifer oxygen record $(G$. 
bulloides and $N$. pachyderma $(\mathrm{R})$ ) in the SBB also signals the development of thermally stratified waters during the upper part of MIS 5e [Friddell et al., 2002] (Figure 3).

\subsubsection{MIS 5d}

Sea level begins to fall $\sim 116 \mathrm{kyr}$ as the insolation curve returns to a summer low and benthic $\delta^{18} \mathrm{O}$ records become heavier as alkenone reconstructed SSTs start to drop all along the California margin (Figure 5A and 5B). Cysts of autotrophic dinoflagellates decline rapidly after zone D4b and the replacement of Spiniferites mirabilis with cysts of an opportunistic Operculodinium centrocarpum and a cold water indicator Selenopemphix undulata, imply a return to cooler unstable transitional marine conditions (Figure 2). The MAT reconstruction deviates from this interpretation, and at this point the qualitative assessment appears to be more accurate. This environmental shift is responsible for the basin returning to conditions similar to MIS 6/D1that was also characterized by decreased PP and absence of laminated sediments.

\subsection{Dinoflagellate (Paleo) Productivity and Sea Surface Temperature Signal}

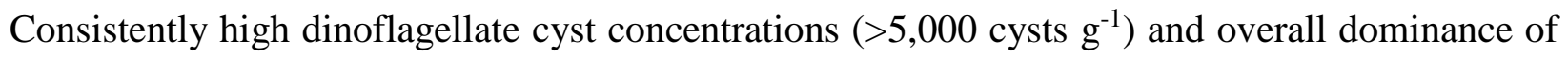
cysts produced by Protoperidiniaceae and mainly Brigantedinium spp. throughout the studied sections are consistent with active upwelling systems on the modern day Pacific northwest [e.g. Pospelova et al., 2008; Bringué et al., 2013]. Reconstructed PP values are in line or a bit higher than the modern seasonal ranges in the SBB and are a consequence of analogue sites off the Oregon coast, which experiences intense upwelling. Overall, a three point running average of the reconstructed marine productivity does not show a close correlation to the trends in the sedimentary total organic carbon (\% TOC) and $\mathrm{CaCO}_{3}(\%)$ record, which are also common proxies of marine productivity (Figure 3) (geochemical data are from Gardner and Dartnell, [1995] and 
Stein and Rack, [1995]). The quantitative reconstruction does not reflect the highest concentrations of cysts produced by heterotrophic dinoflagellates during the latest part of MIS 5e and beginning of MIS 5d except for two small peaks, but these increases in PP do roughly correspond to the only two increases in biogenic opal (\%) and maximum concentrations of foraminiferal organic linings present in this record (Figure 3), and is consistent with marine prey interactions for them to be covariant [e.g. Price and Pospelova, 2011; Bringué et al., 2013]. Other evidence for changes in the $\mathrm{PP}$ in the SBB during the studied interval lies in the variation in the ratio of total cyst concentrations to the total pollen concentrations (Figure 3). As the cyst ratio increases it reflects an increase of marine PP relative to the terrestrial input. The ratio can also be affected by sea level, as before Termination II it was $\sim 120 \mathrm{~m}$ lower than present [Siddall et al., 2006], effectively narrowing the channel at the eastern side of the basin and restricting the warm water circulation within the SBB and enhancing pollen input by a relative increase in proximity of the coast to the ODP Hole 893A (Figure 1B). As sea level rose 133 kyr [e.g. Siddall et al., 2006; Kopp et al., 2009], the channel would have widened and a greater marine PP in the basin most likely dilutes the terrestrial palynomorph input, thus an increased cyst to pollen ratio (Figure 3). The influence of sea level on the coastal proximity and the associated changes in hydrology are inherently tied to nutrient and upwelling potential in the SBB, and as sea level rises to reach modern day or even slightly higher values in the later part of MIS 5e ( 123-117 kyr), the circulation patterns would presumably be reminiscent of the present day configuration that include modern day and Holocene PP levels. Fittingly, the impact of sea level change and the associated environmental conditions that rely on its fluctuation is reflected in the dinoflagellate assemblages. The latter can also be inferred from the second PCA axis; as values become more negative the sea level curve shows a transgression and at peak negative PC2 values $~ 123$ kyr sea level peak occurs [Siddall et al., 2006; Kopp et al., 
2009] along with the peak in total dinoflagellate cysts, which suggests strengthened upwelling (Figures 2 and 3). Increased concentrations of cysts produced by autotrophic dinoflagellates also occur during the greatest heterotrophic dinoflagellate cyst concentration peak, reflecting a greater contribution of dinoflagellates to PP at this time (Figure 3). During most of MIS 6, and into the early interglacial period, relatively low abundances of autotrophic cysts implies that dinoflagellates are contributing rather limited amounts to the source of TOC and reconstructed peaks in PP.

An increase in the abundance of cysts produced by autotrophic dinoflagellates, notably Spiniferites mirabilis, suggests an increase in SST due to a suppressed cooler California Current and/or an enhanced input of warmer waters from the California Countercurrent. Overall species richness is also a good indicator of SST, a higher number of species indicates warmer conditions and the interglacial shows consistently higher SWI and diversity (Figure 3) and this observation is in line with previous dinoflagellate cyst studies along the California margin [Pospelova et al., 2006, 2015]. The H:A ratio was used in Pospelova et al., [2006] successfully as a proxy for paleotemperature in the SBB; a higher ratio indicates cooler temperatures, and is suitably high during MIS 6 and MIS 5d and low during MIS 5e (Figure 3 and Table 3). Used in tandem with the relative abundance changes of dinoflagellate cysts linked to SST, the values of PCA axis 1 can be explained. The lowest PC1 scores are in MIS 6 and 5d, and are characterized by the increase of cysts of Selenopemphix undulata (Figure 2), which is highly correlated with the influence of subpolar/temperate waters coming from the north with the California Current [Pospelova et al., 2006] and is known to inhabit waters with an annual mean SST of $16^{\circ} \mathrm{C}$ or cooler in areas of coastal upwelling [Verleye et al., 2011]. High PC1 scores are associated with the presence of S. mirabilis, which is found in high abundance near the equator [Zonneveld et al., 2013]. In the present, $S$. 
mirabilis in the SBB does not exceed 2\%, but to the south along the Baja coast and into the Gulf of Mexico, relative abundances of this species are $>10 \%$ in waters where the SST is $\sim 18-32^{\circ} \mathrm{C}$ [e.g. Limoges et al., 2015].

The quantitative reconstruction attempts for SST follow the overall trends well (Figure 4), but likely underestimate the values due to analogue sites being selected from more northern latitudes than the SBB; for example, analogues selected off the coast of modern Oregon exhibit August SSTs 5- $6^{\circ} \mathrm{C}$ cooler than the SBB [Radi and de Vernal, 2004; Pospelova, 2008]. As no analogue sites were selected south of the SBB, the reconstruction is prevented from reflecting the "warmer than present" conditions of the LIG. The absence of sites selected from warmer locations is partially explained by the low number of database sites around the SBB, the southern extent of the California Current, and in warmer upwelling areas in general. A taxonomic distinction is also partially responsible, as two species, Selenopemphix undulata and Selenopemphix nephroides, are grouped into S. nephroides in the Geotop database. As S. nephroides is consistently present in low abundances ( $<2 \%)$ throughout most of the core where S. undulata is absent, the cooler SST signal is masked in the quantitative reconstruction. It is recommended to separate these two species in the database in the future.

\subsection{Cyst Preservation}

It was suggested that selective degradation of dinoflagellate cysts could occur in areas of low deposition and long exposure to oxic conditions [e.g. Zonneveld et al., 1997, 2010; Gray et al., 2017]. The SBB is characterised by high depositional rates [e.g. Kennett, 1995], yet a significant negative correlation downcore between the bioturbation index and total cyst concentrations exists. Total dinoflagellate concentrations increase by a factor of 2-5 in the presence of laminated intervals 
(Figure 3), which raises the question if the increase is an artificial consequence of poor cyst preservation during periods of extended oxidized surface sediments denoted by the massive muds in the sedimentary record or the signal is a true reflection of increased PP and export that drives the formation of laminations. Evidence to support the latter appears in the form of visual cyst appearance and preservation of sensitive cysts (i.e cysts of Protoperidinium americanum [Zonneveld et al., 2010]), which do not show signs of thinning or etching of cyst walls in laminated or bioturbated samples. The variation in opal also supports unbiased cyst preservation, as the opal peaks match well to increases in total cyst concentrations, which do not remain high across all the laminated intervals (Figure 3). A correlation between dinoflagellate cyst concentrations and TOC (\%) and opal is also present in the SBB over the last $42 \mathrm{kyr}$ [Pospelova et al., 2006]. Thus we believe the cysts are not affected by selective degradation and directly reflect the environmental conditions.

\subsection{Regional and Global Variances}

As this is the first dinoflagellate cyst study along the California margin that spans the LIG, we cannot compare the cyst paleoenvironmental signal to other cyst records in the northeast Pacific. However, the few LIG records from the Atlantic indicate the use of Spiniferites mirabilis as a marker for MIS 5e conditions is not restricted to the SBB. The highest abundances of S. mirabilis in the North Atlantic were are also found during MIS 5e under the influence of warm surficial North Atlantic Drift waters encroaching into higher latitudes [e.g. Penaud et al., 2008]. Based on visual inspection of the cold and warm water indicator cyst taxa and other SST sedimentary proxies (e.g H:A ratio, diversity...), interglacial conditions are interpreted to span from $~ 136-118$ kyr with a cooling period from $\sim 130-129$ kyr associated with a short sea level drop or still-stand, but if $S$. 
mirabilis abundances are considered as a good marker for warm conditions, the period prior to MIS 5e is seen as transitional across Termination II and the climatic optimum or MIS 5e plateau would be restricted to $\sim 128-118 \mathrm{kyr}$. The LR04 global benthic $\delta^{18} \mathrm{O}$ curve identifies the sea level rise pause and defines MIS5e after it starts rising again, so that the duration of this interval is similar to our record. Inter-MIS 5e cool periods $\sim 119 \mathrm{kyr}$ in the North Atlantic [e.g. Galaasan et al., 2014; Helmens et al., 2015] records may be a signal of the end climatic optimum in the Pacific, but any conclusions drawn on cross-ocean phases are reliant on the correctness of the various age models used and definition of the interglacial itself.

\subsection{Comparison of MIS 5e to the Holocene and present}

Sea surface warming during the last glacial-interglacial transition along the California margin was not synchronous with deglaciation, as maximum benthic oxygen lightening occurs after alkenone data shows a warming that can be attributed to the weakening of the California Current and the encroachment of warmer Pacific Gyre water [Herbert et al., 2001]. The use of four paleo alkenone records from the California margin [Herbert et al., 1995, 2001; Yamamoto et al., 2007] from MIS 2 and 1 indicates early SST warming is most apparent at the southern boundary of the California Current near ODP Hole 1012B, where the alkenone SST reconstruction shows a rapid warming $\sim 23 \mathrm{kyr}$ (Figure 5A). Moving north, ODP Hole 1014A, 893A, and 1016C shows that the warming is gradual and the timing lags one to two thousand years (Figures 1 and 4). A similar pattern emerges during Termination II with alkenone SST rapidly rising at ODP Hole 1012B $\sim 5 \mathrm{kyr}$ before the rise gradually moves north until SSTs become a little bit warmer than the Holocene 134-133 kyr. After this first peak in SST the LIG pattern diverges from the Holocene, and the alkenone record from ODP Hole 1014A and 893A shows a brief dip in SST 130-129 kyr corresponding 
with dinoflagellate zone D3. By the latest part of MIS 5e, at each site SST peaks $3-5^{\circ} \mathrm{C}$ warmer than the corresponding Holocene SST optimums (Figure 4). The deviation of interglacial evolution is most likely a combination of insolation and hydrological differences; the MIS 5e insolation maximum does not occur until after the first rapid SST rise, and abundances of Spiniferites mirabilis in ODP Hole $893 \mathrm{~A}>1 \%$ do not occur in MIS 1 suggesting subtropical waters from the California Countercurrent were not as large an influence.

While the intensity of the LIG is noticeably different, the dinoflagellate cyst assemblages from the SBB have relatively similar assemblages for the interval from MIS 6 to 5d to those from the Holocene or the present [Pospelova et al., 2006, Bringué et al., 2013, and Bringué et al., 2014]. Notable differences stem from the lack or low abundances/concentrations of Echinidinium spp., $L$. machaerophorum, Polykrikos spp., and Votadinium spp. within the samples from MIS 6-5d. Relative abundances of L. machaerophorum never reach above $5 \%$ before a thousand years ago in the SBB [Pospelova et al., 2006], indicating some environmental parameter in the SBB must have shifted at that time. Conversely, MIS 5e has significantly more Spiniferites mirabilis than the past $40 \mathrm{kyr}$, and rare occurrences of taxa restricted to descriptions in the Pleistocene. The absence of those taxa after MIS 5e also suggests an overturning in the species assemblages from MIS 5e to MIS 3 and 1 occurred due to an environmental stressor or overall decrease in SST in the SBB. This study documents cysts of $P$. americanum during MIS 5e, and this extends the stratigraphic range of this species beyond the Holocene, and as it appears in greatest abundances during MIS 5e and the latest part of the Holocene a SST component may be significant in its appearance.

Along with individual species differences, the structure and development of the interglacial based on the Dinoflagellate cyst zones for MIS 1 and 2 proposed by Pospelova et al., [2006] in the SBB from ODP Hole 893A are comparable to the Zones for MIS 5e and 6 in this 
study; low total cyst concentrations ( 5,000 cysts $\left.\mathrm{g}^{-1}\right)$ mark both MIS 2 and MIS 6 , the blue zones in Figure 4, and the autotrophic and heterotrophic dinoflagellate cyst concentrations show an increase (red zones) into interglacial conditions to a maximum in the latest interglacial (purple zones). The dinoflagellate species richness between glacial to interglacial zones in the SBB is also very similar with an increase from 12 to 17 and 13 to 17 between MIS 2 to 1 and MIS 6 to 5e. However, there is no evidence for a transitional dinoflagellate cyst assemblage or short zone indicating cooling between MIS 2 and 1 in the SBB that would correlate to D2 and D3 in this study.

To the north at ODP Hole 1017E, the dinoflagellate cyst transitional assemblages from the end of MIS 2 into MIS 1, i.e the transition from the YD to the Holocene, from Pospelova et al., [2015] appears to be very similar to the assemblages of zone D2 of this study (Figure 2); Selenopemphix undulata drops to negligible values, oceanic taxa reaches a maximum, Trinovantedinium variabile briefly occurs in abundances $>1.5 \%$, and relative abundances of Selenopemphix quanta are at a maximum right before the onset of the Holocene. The interpretation of the Younger Dryas dinoflagellate assemblage at Point Conception [Pospelova et al., 2015] and further south in the Guaymas Basin [Price et al., 2013] is general low primary productivity and warm SSTs typical of increased strength of the California Countercurrent during this time before a reorganization of the terrestrial vegetation and increase in marine productivity in the Holocene. A minor cooling interval $\sim 8 \mathrm{kyr}$ is also supported by the dinoflagellate cyst abundances and brief drop in species richness at ODP Hole 1017E [Pospelova et al., 2015]. Together, the dinoflagellate cyst glacial-interglacial transition at Point Conception is remarkably similar to the D2-D4b sequence of the LIG in the SBB in cyst assemblage and overall climatic interpretation (Figure 4). 


\section{Conclusion}

A well preserved dinoflagellate cyst record from ODP Leg 146, Hole 893A documents submillennial changes in primary productivity and sea surfaces temperatures in the Santa Barbara Basin from 110 to $155 \mathrm{kyr}$. This is the first and only successful dinoflagellate cyst study of the last interglacial along the Pacific Northwest to provide the cyst record and reconstruct PP and SST.

- Variations in the relative abundances of Spiniferites mirabilis, Selenopemphix undulata, Operculodinium centrocarpum, and Brigantedinium spp. mark the major changes across MIS 6, 5e, and 5d.

- Unstable hydrological conditions in the SBB are present before the insolation peak, suggesting Termination II had a different triggering mechanism.

- Statistical analysis of dinoflagellate cyst data suggests that SST changes caused by insolation and the changing influence of the California Countercurrent are responsible for the primary PCA axis 1, while sea level changes in the SBB control upwelling, circulation, the availability of nutrients, and are reflected in PCA axis 2.

- Warmest SST occur in dinoflagellate zones D4a and D4b, which correspond to MIS 5e, while cool SST are reflected in D1, D3, and D5.

- PP in the SBB does not reach modern day levels until D4b or the late part of MIS 5e, when sea level conditions stabilize near modern levels and dinoflagellate cyst concentrations are dominated by upwelling-related taxa at this time.

- Dinoflagellate cyst climate data are in agreement with alkenone SST reconstructions and pollen records at the site. The use of the H:A ratio and species richness are justified as good proxies for direction of SST change. 
- A short lived cold event, observed in the benthic $\delta^{18} \mathrm{O}$ record of ODP Hole 1017E and in the global LR04 benthic stack, can be seen in our dinoflagellate cyst record in the SBB.

- The dinoflagellate cyst expression of the transition from the Bølling-Allerød to the Younger Dryas to the Holocene ( 14-9 kyr) conditions in ODP Hole 1017E (north of the SBB) is very similar to the glacial-interglacial transition seen between cyst zones D1 and D2 ( 141-130 kyr) of this study.

- The Holocene dinoflagellate cyst concentrations in the SBB are consistent with late MIS 5e concentrations at the site. Both records indicate increased upwelling conditions, although the MIS 5e concentrations of S. mirabilis indicate that SSTs were higher.

The level of detail the dinoflagellate cyst record provides demonstrates their use as an important proxy for reconstructing past hydrological conditions in future studies. The poor preservation of diatoms and foraminifera due to dissolution in ODP Sites 1018 and 1020 off of northern California during the LIG make them ideal candidates for using resistant dinoflagellate cysts as a proxy for understanding the hydrological changes of the California Current system at higher latitudes. The success of capturing submillenial scale changes at a $0.5 \mathrm{~m}$ sampling resolution means that a higher resolution study in the SBB has the potential to resolve centennial to subcentennial variation and could potentially offer insight to the role of Pacific Decadal Oscillation on Termination II. 


\section{References}

A

Andreasen, D., Flower, M., Harvey, M., Chang, S., Ravelo, A.C., Datareport: Late Pleistocene oxygen and carbon isotopic records from ODP Leg 167 Sites 1011, 1012, and 1018. Proceedings of the Ocean Drilling Program. Scientific Results, 167.

Aubry, A.M.R., de Vernal, A., Hillaire-Marcel, C., 2016. The "warm" Marine Isotope Stage 31 in the Labrador Sea: Low surface salinities and cold subsurface waters prevented winter convection. Paleoceanography 31, 1206-1224. doi:10.1002/2015PA002903

B

Behl, R.J., 1995. Data report: detailed lithostratigraphy of Hole 893A, Santa Barbara Basin, southern California continental borderland. In Kennett, J.P., Baldauf, J.G., and Lyle, M. (Eds.), Proc. ODP, Sci. Results, 146 (Pt. 2): College Station, TX (Ocean Drilling Program), 347-351. doi:10.2973/odp.proc.sr.146-2.309.1995

Behl, R.J. and Kennett, J.P., 1996. Brief interstadial events in the Santa Barbara basin, NE Pacific, during the past 60 kyr. Nature, 379(6562), p.243.

Berger, A., 1978. Long-term variations of daily insolation and Quaternary climatic changes. Journal of the atmospheric sciences, 35(12), pp.2362-2367.

Brewer, S., Guiot, J., Sánchez-Goñi, M.F. and Klotz, S., 2008. The climate in Europe during the Eemian: a multi-method approach using pollen data. Quaternary Science Reviews, 27(2526), pp.2303-2315.

Bringué, M., Pospelova, V. and Pak, D., 2013. Seasonal production of organic-walled dinoflagellate cysts in an upwelling system: a sediment trap study from the Santa Barbara Basin, California. Marine Micropaleontology, 100, pp.34-51.

Bringué, M., Pospelova, V. and Field, D.B., 2014. High resolution sedimentary record of dinoflagellate cysts reflects decadal variability and 20th century warming in the Santa Barbara Basin. Quaternary Science Reviews, 105, pp.86-101.

Broecker, W.S., 1993. The glacial world according to Wally. Lamont-Doherty earth observatory of Columbia University., 318.

Brzezinski, M.A. and Washburn, L., 2011. Phytoplankton primary productivity in the Santa Barbara Channel: Effects of wind - driven upwelling and mesoscale eddies. Journal of Geophysical Research: Oceans, 116(C12). 
Byrne, R., Mudie, P., and Soutar, A., 1990. A pollen/dinoflagellate chronology for DSDP Site 480, Gulf of California. In: Sixth Annual Pacific Climate (PACLIM) Workshop , 5-8 March 1989, Asilomar Conference Center, Pacific Grove, CA, pp.105-110.

C

Chang, T.S., Kim, J.C. and Yi, S., 2014. Discovery of Eemian marine deposits along the Baeksu tidal shore, southwest coast of Korea. Quaternary international, 349, pp.409-418.

\section{D}

Dale, B., 1976. Cyst formation, sedimentation, and preservation: factors affecting dinoflagellate assemblages in recent sediments from Trondheimsfjord, Norway. Review of Palaeobotany and Palynology, 22(1), pp.39-60.

Dale, B., 1996. Dinoflagellate cyst ecology: modeling and geological applications. Palynology: principles and applications, pp.1249-1275.

De Vernal, A., Rochon, A., Turon, J.L. and Matthiessen, J., 1997. Organic-walled dinoflagellate cysts: palynological tracers of sea-surface conditions in middle to high latitude marine environments. Geobios, 30(7), pp.905-920.

De Vernal, A., Henry, M., Matthiessen, J., Mudie, P.J., Rochon, A., Boessenkool, K.P., Eynaud, F., GrØsfjeld, K., Guiot, J., Hamel, D. and Harland, R., 2001. Dinoflagellate cyst assemblages as tracers of sea - surface conditions in the northern North Atlantic, Arctic and sub - Arctic seas: The new ' $n=677$ ' data base and its application for quantitative palaeoceanographic reconstruction. Journal of Quaternary Science: Published for the Quaternary Research Association, 16(7), pp.681-698.

De Vernal, A., Eynaud, F., Henry, M., Hillaire-Marcel, C., Londeix, L., Mangin, S., Matthießen, J., Marret, F., Radi, T., Rochon, A. and Solignac, S., 2005. Reconstruction of sea-surface conditions at middle to high latitudes of the Northern Hemisphere during the Last Glacial Maximum (LGM) based on dinoflagellate cyst assemblages. Quaternary Science Reviews, 24(7), pp.897-924.

De Vernal, A., Van Nieuwenhove, N., Radi, T., Ouellet-Bernier, M.M. and Peyrede, L., 2013. Dinocyst assemblages as proxies of sea-surface conditions: towards quantitative approaches in Late Cenozoic paleoceanography In 10th international conference on modern and fossil dinoflagellates. 
Doose, H., Prahl, F.G. and Lyle, M.W., 1997. Biomarker temperature estimates for modern and last glacial surface waters of the California Current system between 33 and $42 \mathrm{~N}$. Paleoceanography, 12(4), pp.615-622.

Dunbar, R.B. and Berger, W.H., 1981. Fecal pellet flux to modern bottom sediment of Santa Barbara Basin (California) based on sediment trapping. Geological Society of America Bulletin, 92(4), pp.212-218.

$\mathbf{E}$

Eichhubl, P., Greene, H.G. and Maher, N., 2002. Physiography of an active transpressive margin basin: high-resolution bathymetry of the Santa Barbara basin, Southern California continental borderland. Marine Geology, 184(1-2), pp.95-120.

Ellegaard, M., Dale, B., Mertens, K.N., Pospelova, V. and Ribeiro, S., 2017. Dinoflagellate cysts as proxies for holocene environmental change in estuaries: diversity, abundance and morphology. In Applications of Paleoenvironmental Techniques in Estuarine Studies (pp. 295-312). Springer, Dordrecht.

Emery, K.O., 1960. The sea off southern California, a modern habitat of petroleum.

Epstein, S., Buchsbaum, R., Lowenstam, H.A. and Urey, H.C., 1953. Revised carbonate-water isotopic temperature scale. Geological Society of America Bulletin, 64(11), pp.13151326.

Eynaud, F., Turon, J.L. and Duprat, J., 2004. Comparison of the Holocene and Eemian palaeoenvironments in the South Icelandic Basin: dinoflagellate cysts as proxies for the North Atlantic surface circulation. Review of Palaeobotany and Palynology, 128(1-2), pp.55-79.

$\mathbf{F}$

Fisler, J. and Hendy, I.L., 2008. California Current System response to late Holocene climate cooling in southern California. Geophysical Research Letters, 35(9).

Friddell, J.E., Thunell, R.C. and Heusser, L.E., 2002. Direct comparison of marine and terrestrial climate variability during marine isotope stages 6 and 5: Results from Santa Barbara Basin ODP Hole 893A. Paleoceanography and Paleoclimatology, 17(1).

G

Galaasen, E.V., Ninnemann, U.S., Irvalı, N., Kleiven, H.K.F., Rosenthal, Y., Kissel, C. and Hodell, D.A., 2014. Rapid reductions in North Atlantic deep water during the peak of the last interglacial period. Science, 343(6175), pp.1129-1132. 
Gardner, J.V., and Dartnell, P., 1995. Centennial-scale late Quaternary stratigraphies of carbonate and organic carbon from Santa Barbara Basin, Hole 893A, and their paleoceanographic significance. In J.P., Baldauf, J.G., and Lyle, M. (Eds.), Proc. ODP, Sci. Results, 146 (Pt. 2): College Station, TX (Ocean Drilling Program), 103-124. doi:10.2973/odp.proc.sr.146-2.290.1995

Goñi, M.S., Turon, J.L., Eynaud, F., Shackleton, N.J. and Cayre, O., 2000. Direct land/sea correlation of the Eemian, and its comparison with the Holocene: a high-resolution palynological record off the Iberian margin. Geologie en Mijnbouw, 79(2/3), pp.345-356.

Goñi, M.S., Loutre, M.F., Crucifix, M., Peyron, O., Santos, L., Duprat, J., Malaizé, B., Turon, J.L. and Peypouquet, J.P., 2005. Increasing vegetation and climate gradient in Western Europe over the Last Glacial Inception (122-110 ka): data-model comparison. Earth and Planetary Science Letters, 231(1-2), pp.111-130.

Granoszewski, W., Demske, D., Nita, M., Heumann, G. and Andreev, A.A., 2005. Vegetation and climate variability during the Last Interglacial evidenced in the pollen record from Lake Baikal. Global and Planetary Change, 46(1-4), pp.187-198.

Gray, D.D., Zonneveld, K.A. and Versteegh, G.J., 2017. Species-specific sensitivity of dinoflagellate cysts to aerobic degradation: A five-year natural exposure experiment. Review of Palaeobotany and Palynology, 247, pp.175-187.

$\mathbf{H}$

Hammer, Ø., Harper, D.A.T., Ryan, P.D. 2001. PAST: Paleontological statistics software package for education and data analysis. Palaeontologia Electronica 4(1): 9pp. http://palaeo-electronica.org/2001_1/past/issue1_01.htm

Hardy, W., Marret, F., Penaud, A., le Mézo, P., Droz, L., Marsset, T. and Kageyama, M., 2018. Quantification of last glacial-Holocene net primary productivity and upwelling activity in the equatorial eastern Atlantic with a revised modern dinocyst database.

Palaeogeography, Palaeoclimatology, Palaeoecology.

Harland, R., 1983. Distribution maps of recent dinoflagellate cysts in bottom sediments from the North Atlantic Ocean and adjacent seas. Palaeontology, 26(2), pp.321-387.

Head, M.J., 1996. Modern dinoflagellate cysts and their biological affinities. Palynology: principles and applications, 3, pp.1197-1248.

Head, M.J., Seidenkrantz, M.S., Janczyk-Kopikowa, Z., Marks, L. and Gibbard, P.L., 2005. Last Interglacial (Eemian) hydrographic conditions in the southeastern Baltic Sea, NE Europe, based on dinoflagellate cysts. Quaternary International, 130(1), pp.3-30. 
Hearty, P.J., Hollin, J.T., Neumann, A.C., O’Leary, M.J. and McCulloch, M., 2007. Global sealevel fluctuations during the Last Interglaciation (MIS 5e). Quaternary Science Reviews, 26(17-18), pp.2090-2112.

Helmens, K.F., Salonen, J.S., Plikk, A., Engels, S., Väliranta, M., Kylander, M., Brendryen, J. and Renssen, H., 2015. Major cooling intersecting peak Eemian Interglacial warmth in northern Europe. Quaternary Science Reviews, 122, pp.293-299.

Hendy, I.L. and Kennett, J.P., 1999. Latest Quaternary North Pacific surface-water responses imply atmosphere-driven climate instability. Geology, 27(4), pp.291-294.

Hendy, I.L. and Kennett, J.P., 2000. Dansgaard - Oeschger cycles and the California Current System: Planktonic foraminiferal response to rapid climate change in Santa Barbara Basin, Ocean Drilling Program hole 893A. Paleoceanography, 15(1), pp.30-42.

Hendy, I.L., Pedersen, T.F., Kennett, J.P. and Tada, R., 2004. Intermittent existence of a southern Californian upwelling cell during submillennial climate change of the last 60 kyr. Paleoceanography, 19(3).

Herbert, T.D., Yasuda, M., and Burnett, C., 1995. Glacial-interglacial sea-surface temperature record inferred from alkenone unsaturation indices, Site 893, Santa Barbara Basin. In Kennett, J.P., Baldauf, J.G., and Lyle, M. (Eds.), Proc. ODP, Sci. Results, 146 (Pt. 2): College Station, TX (Ocean Drilling Program), 257-264. doi:10.2973/odp.proc.sr.1462.301.1995

Herbert, T.D., Schuffert, J.D., Thomas, D., Lange, C., Weinheimer, A., Peleo - Alampay, A. and Herguera, J.C., 1998. Depth and seasonality of alkenone production along the California margin inferred from a core top transect. Paleoceanography, 13(3), pp.263-271.

Herbert, T.D., 2001. California Current Reconstruction from Benthic Isotopes and Alkenone Temperatures. IGBP PAGES/World Data Center A for Paleoclimatology Data Contribution Series \#2001-058. NOAA/NGDC Paleoclimatology Program, Boulder CO, USA.

Heusser, L.E. and Sirocko, F., 1997. Millennial pulsing of environmental change in southern California from the past $24 \mathrm{ky}$ : A record of Indo-Pacific ENSO events?. Geology, 25(3), pp.243-246.

Heusser, L.E., 2000. Rapid oscillations in western North America vegetation and climate during oxygen isotope stage 5 inferred from pollen data from Santa Barbara Basin (Hole 893A). Palaeogeography, Palaeoclimatology, Palaeoecology, 161(3-4), pp.407-421.

Hickey, B.M., 1998. Coastal oceanography of western North America from the tip of Baja California to Vancouver Island. The sea, 11, pp.345-393. 
Hopkins, J.A., 2002. Post-depositional palynomorph degradation in Quaternary shelf sediments: a laboratory experiment studying the effects of progressive oxidation. Palynology, 26(1), pp.167-184.

\section{I}

Ivanochko, T.S. and Pedersen, T.F., 2004. Determining the influences of Late Quaternary ventilation and productivity variations on Santa Barbara Basin sedimentary oxygenation: a multi-proxy approach. Quaternary Science Reviews, 23(3-4), pp.467-480.

\section{$\mathbf{J}$}

Jacobson, D.M. and Anderson, D.M., 1996. Widespread phagocytosis of ciliates and other protists by marine mixotrophic and heterotrophic thecate dinoflagellates 1 . Journal of Phycology, 32(2), pp.279-285.

$\mathbf{K}$

Kennett, J.P., Baldauf, J.G., et al., 1994. Proc. ODP, Init. Repts., 146 (Pt. 2): College Station, TX (Ocean Drilling Program). doi:10.2973/odp.proc.ir.146-2.1994

Kennett, J.P., and Ingram, B.L., 1995. Paleoclimatic evolution of Santa Barbara Basin during the last 20 k.y.: marine evidence from Hole 893A. In Kennett, J.P., Baldauf, J.G., and Lyle, M. (Eds.), Proc. ODP, Sci. Results, 146 (Pt. 2): College Station, TX (Ocean Drilling Program), 309-325. doi:10.2973/odp.proc.sr.146-2.296.1995

Kennett, J.P., 1995. Latest Quaternary benthic oxygen and carbon isotope stratigraphy: Hole 893A, Santa Barbara Basin, California. In: Kennett, J.P., Baldauf, J.G., Lyle, M. (Eds.), Proc. ODP Sci. Results 146, 3-18.

Kennett, J.P., Roark, E.B., Cannariato, K.G., Ingram, B.L. and Tada, R., 2000. 21. Late Quaternary paleoclimatic and radiocarbon chronology, Hole 1017E, southern California Margin. In Ocean Drill. Program, Sci. Results (Vol. 167, pp. 249-254).

Koide, M., Soutar, A. and Goldberg, E.D., 1972. Marine geochronology with ${ }^{210} \mathrm{~Pb}$. Earth and Planetary Science Letters, 14(3), pp.442-446.

Kopp, R.E., Simons, F.J., Mitrovica, J.X., Maloof, A.C. and Oppenheimer, M., 2009. Probabilistic assessment of sea level during the last interglacial stage. Nature, 462(7275), p.863.

Kreitz, S.F., Herbert, T.D. and Schuffert, J.D., 2000. Alkenone paleothermometry and orbitalscale changes in sea-surface temperature at Site 1020, northern California margin. In Proceedings of the Ocean Drilling Program, Scientific Results (Vol. 167, pp. 153-161). College Station, Tex.: Ocean Drill. Program. 
Kukla, G., McManus, J.F., Rousseau, D.D. and Chuine, I., 1997. How long and how stable was the last interglacial? Quaternary Science Reviews, 16(6), pp.605-612.

$\mathbf{L}$

Lepš, J. and Šmilauer, P., 2003. Multivariate analysis of ecological data using CANOCO. Cambridge university press.

Limoges, A., de Vernal, A. and Ruiz-Fernández, A.C., 2015. Investigating the impact of land use and the potential for harmful algal blooms in a tropical lagoon of the Gulf of Mexico. Estuarine, Coastal and Shelf Science, 167, pp.549-559.

Lisiecki, L.E. and Raymo, M.E., 2005. A Pliocene - Pleistocene stack of 57 globally distributed benthic $\delta 180$ records. Paleoceanography, 20(1).

Lynn, R.J. and Simpson, J.J., 1987. The California Current System: The seasonal variability of its physical characteristics. Journal of Geophysical Research: Oceans, 92(C12), pp.12947-12966.

$\mathbf{M}$

MacRae, R.A., Fensome, R.A. and Williams, G.L., 1996. Fossil dinoflagellate diversity, originations, and extinctions and their significance. Canadian Journal of Botany, 74(11), pp.1687-1694.

Marret, F., Vernal, A.D., Pedersen, T.F. and McDonald, D., (2001a). Middle Pleistocene to Holocene palynostratigraphy of ocean drilling program site 887 in the Gulf of Alaska, northeastern North Pacific. Canadian Journal of Earth Sciences, 38(3), pp. 373-386.

Maslin, M., Sarnthein, M. and Knaack, J.J., 1996. Subtropical eastern Atlantic climate during the Eemian. Naturwissenschaften, 83(3), pp.122-126.

Matsuoka, K., 1979. Hystrichokolpoma from pleistocene sediments in Okinawa-Jima, Japan. Review of Palaeobotany and Palynology, 28(1), pp.47-60.

Mertens, K.N., Verhoeven, K., Verleye, T., Louwye, S., Amorim, A., Ribeiro, S., Deaf, A.S., Harding, I.C., De Schepper, S., González, C. and Kodrans-Nsiah, M., 2009. Determining the absolute abundance of dinoflagellate cysts in recent marine sediments: the Lycopodium marker-grain method put to the test. Review of Palaeobotany and Palynology, 157(3), pp.238-252.

Mertens, K.N., Price, A.M. and Pospelova, V., 2012. Determining the absolute abundance of dinoflagellate cysts in recent marine sediments II: further tests of the Lycopodium marker-grain method. Review of Palaeobotany and Palynology, 184, pp.74-81. 
Myers, R.L., Erlandson, J.M., Muhs, D.R. and Rick, T.C., 2015. Sea level, paleogeography, and archeology on California's Northern Channel Islands. Quaternary Research, 83(2), pp. 263-272.

Muhs, D.R., Simmons, K.R., Kennedy, G.L. and Rockwell, T.K., 2002. The last interglacial period on the Pacific Coast of North America: Timing and paleoclimate. Geological Society of America Bulletin, 114(5), pp.569-592.

$\mathbf{P}$

Penaud, A., Eynaud, F., Turon, J.L., Zaragosi, S., Marret, F. and Bourillet, J.F., 2008. Interglacial variability (MIS 5 and MIS 7) and dinoflagellate cyst assemblages in the Bay of Biscay (North Atlantic). Marine Micropaleontology, 68(1-2), pp.136-155.

Petit, J.R., Jouzel, J., Raynaud, D., Barkov, N.I., Barnola, J.M., Basile, I., Bender, M., Chappellaz, J., Davis, M., Delaygue, G. and Delmotte, M., 1999. Climate and atmospheric history of the past 420,000 years from the Vostok ice core, Antarctica. Nature, 399(6735), p.429.

Pisias, N.G., Mix, A.C. and Heusser, L., 2001. Millennial scale climate variability of the northeast Pacific Ocean and northwest North America based on radiolaria and pollen. Quaternary Science Reviews, 20(14), pp.1561-1576.

Poore, R.Z., Dowsett, H.W., Barron, J.A., Heusser, L., Ravelo, C., and Mix, A.C., 2000, Multiproxy record of the last interglacial (MIS 5e) off central and northern California: U.S. Geological Survey Professional Paper 1632, 19 p.

Pospelova, V., Chmura, G.L. and Walker, H.A., 2004. Environmental factors influencing the spatial distribution of dinoflagellate cyst assemblages in shallow lagoons of southern New England (USA). Review of Palaeobotany and Palynology, 128(1-2), pp.7-34.

Pospelova, V., Chmura, G.L., Boothman, W.S. and Latimer, J.S., 2005. Spatial distribution of modern dinoflagellate cysts in polluted estuarine sediments from Buzzards Bay (Massachusetts, USA) embayments. Marine Ecology Progress Series, 292, pp.23-40.

Pospelova, V., Pedersen, T.F. and de Vernal, A., 2006. Dinoflagellate cysts as indicators of climatic and oceanographic changes during the past $40 \mathrm{kyr}$ in the Santa Barbara Basin, southern California. Paleoceanography and Paleoclimatology, 21(2).

Pospelova, V., de Vernal, A. and Pedersen, T.F., 2008. Distribution of dinoflagellate cysts in surface sediments from the northeastern Pacific Ocean (43-25 N) in relation to sea- 
surface temperature, salinity, productivity and coastal upwelling. Marine Micropaleontology, 68(1-2), pp.21-48.

Pospelova, V., Price, A.M. and Pedersen, T.F., 2015. Palynological evidence for late Quaternary climate and marine primary productivity changes along the California margin. Paleoceanography and Paleoclimatology, 30(7), pp.877-894.

Price, A.M., Mertens, K.N., Pospelova, V., Pedersen, T.F. and Ganeshram, R.S., 2013. Late Quaternary climatic and oceanographic changes in the Northeast Pacific as recorded by dinoflagellate cysts from Guaymas Basin, Gulf of California (Mexico). Paleoceanography, 28(1), pp.200-212.

Price, A.M., Baustian, M.M., Turner, R.E., Rabalais, N.N. and Chmura, G.L., 2018. Dinoflagellate Cysts Track Eutrophication in the Northern Gulf of Mexico. Estuaries and Coasts, 41(5), pp.1322-1336.

$\mathbf{R}$

Radi, T., Pospelova, V., de Vernal, A. and Barrie, J.V., 2007. Dinoflagellate cysts as indicators of water quality and productivity in British Columbia estuarine environments. Marine Micropaleontology, 62(4), pp.269-297.

Radi, T. and de Vernal, A., 2008. Dinocysts as proxy of primary productivity in mid-high latitudes of the Northern Hemisphere. Marine Micropaleontology, 68(1-2), pp.84-114.

Rochon, A., Vernal, A.D., Turon, J.L., Matthießen, J. and Head, M.J., 1999. Distribution of recent dinoflagellate cysts in surface sediments from the North Atlantic Ocean and adjacent seas in relation to sea-surface parameters. American Association of Stratigraphic Palynologists Contribution Series, 35, pp.1-146.

$\mathbf{S}$

Shackleton, N.J., Sánchez-Goñi, M.F., Pailler, D. and Lancelot, Y., 2003. Marine isotope substage 5e and the Eemian interglacial. Global and Planetary change, 36(3), pp.151-155.

Shipe, R.F. and Brzezinski, M.A., 2003. Siliceous plankton dominate primary and new productivity during the onset of El Nino conditions in the Santa Barbara Basin, California. Journal of marine systems, 42(3-4), pp.127-143.

Sholkovitz, E.R. and Gieskes, J.M., 1971. A physical-chemical study of the flushing of the Santa Barbara Basin 1. Limnology and Oceanography, 16(3), pp.479-489. 
Shumilovskikh, L.S., Marret, F., Fleitmann, D., Arz, H.W., Nowaczyk, N. and Behling, H., 2013. Eemian and Holocene sea-surface conditions in the southern Black Sea: organicwalled dinoflagellate cyst record from core 22-GC3. Marine Micropaleontology, 101, pp.146-160.

Siddall, M., Bard, E., Rohling, E.J. and Hemleben, C., 2006. Sea-level reversal during Termination II. Geology, 34(10), pp.817-820.

Stockmarr, J.A., 1971. Tabletes with spores used in absolute pollen analysis. Pollen spores, 13, pp.615-621.

Streel, M. and Bless, M.J.M., 1980. Occurrence and significance of reworked palynomorphs. Mededelingen-Rijks Geologische Dienst, 32(10), pp.69-80.

Stein, R. and Rack, F.R., 1992. A 160,000-year high-resolution record of quantity and composition of organic carbon in the Santa Barbara Basin (Site 893). In proceedingsOcean Drilling Program scientific results (pp. 125-138). National Science Foundation.

$\mathbf{T}$

Thunell, R.C., 1998. Particle fluxes in a coastal upwelling zone: sediment trap results from Santa Barbara Basin, California. Deep Sea Research Part II: Topical Studies in Oceanography, 45(8-9), pp.1863-1884.

$\mathbf{V}$

Van Nieuwenhove, N. and Bauch, H.A., 2008. Last interglacial (MIS 5e) surface water conditions at the Vøring Plateau (Norwegian Sea), based on dinoflagellate cysts. Polar Research, 27(2), pp.175-186.

Verleye, T.J., Pospelova, V., Mertens, K.N. and Louwye, S., 2011. The geographical distribution and (palaeo) ecology of Selenopemphix undulata sp. nov., a new late Quaternary dinoflagellate cyst from the Pacific Ocean. Marine Micropaleontology, 78(3), pp.65-83.

Versteegh, G.J. and Blokker, P., 2004. Resistant macromolecules of extant and fossil microalgae. Phycological Research, 52(4), pp.325-339.

$\mathbf{W}$

Williams, G.L., Fensome, R.A. and MacRae, R.A., 2017: The Lentin and Williams index of fossil dinoflagellates 2017 edition. American Association of Stratigraphic Palynologists Contributions Series, no. 48 
Winant, C.D., Dever, E.P. and Hendershott, M.C., 2003. Characteristic patterns of shelf circulation at the boundary between central and southern California. Journal of Geophysical Research: Oceans, 108(C2).

Winograd, I.J., Coplen, T.B., Landwehr, J.M., Riggs, A.C., Ludwig, K.R., Szabo, B.J., Kolesar, P.T. and Revesz, K.M., 1992. Continuous 500,000-year climate record from vein calcite in Devils Hole, Nevada. Science, 258(5080), pp.255-260.

$\mathbf{Y}$

Yamamoto, M., Yamamuro, M. and Tanaka, Y., 2007. The California current system during the last 136,000 years: response of the North Pacific High to precessional forcing. Quaternary Science Reviews, 26(3), pp.405-414.

$\mathbf{Z}$

Zonneveld, K.A., Versteegh, G.J. and de Lange, G.J., 1997. Preservation of organic-walled dinoflagellate cysts in different oxygen regimes: a 10,000 year natural experiment. Marine micropaleontology, 29(3-4), pp.393-405.

Zonneveld, K.A., Bockelmann, F. and Holzwarth, U., 2007. Selective preservation of organicwalled dinoflagellate cysts as a tool to quantify past net primary production and bottom water oxygen concentrations. Marine Geology, 237(3), pp.109-126.

Zonneveld, K.A., Versteegh, G. and Kodrans-Nsiah, M., 2008. Preservation and organic chemistry of Late Cenozoic organic-walled dinoflagellate cysts: a review. Marine Micropaleontology, 68(1-2), pp.179-197.

Zonneveld, K.A.F., Versteegh, G.J.M., Kasten, S., Eglinton, T.I., Emeis, K.C., Huguet, C., Koch, B.P., de Lange, G.J., De Leeuw, J.W., Middelburg, J.J. and Mollenhauer, G., 2010. Selective preservation of organic matter in marine environments; processes and impact on the sedimentary record. Biogeosciences, 7(2), pp.483-511.

Zonneveld, K.A., Marret, F., Versteegh, G.J., Bogus, K., Bonnet, S., Bouimetarhan, I., Crouch, E., de Vernal, A., Elshanawany, R., Edwards, L. and Esper, O., 2013. Atlas of modern dinoflagellate cyst distribution based on 2405 data points. Review of Palaeobotany and Palynology, 191, pp.1-197.

Zonneveld, K.A. and Pospelova, V., 2015. A determination key for modern dinoflagellate cysts. Palynology, 39(3), pp.387-409. 


\section{Appendix A. Paylnological counts data}

\begin{tabular}{|c|c|c|c|c|c|c|c|c|c|c|c|c|c|c|c|c|c|c|c|}
\hline b & 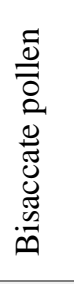 & 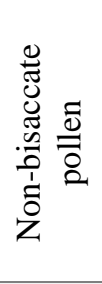 & 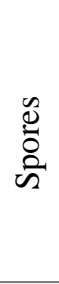 & 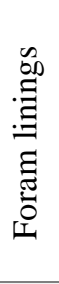 & 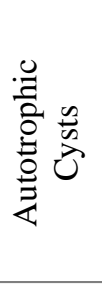 & 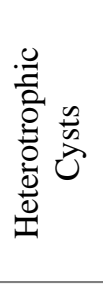 & 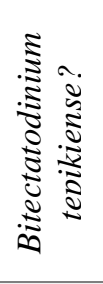 & 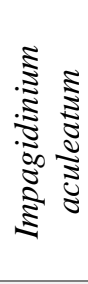 & 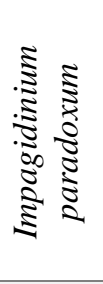 & 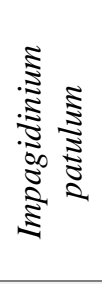 & 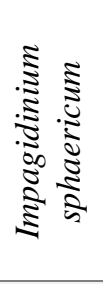 & 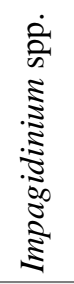 & 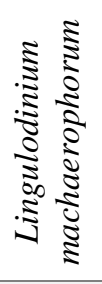 & 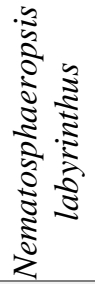 & 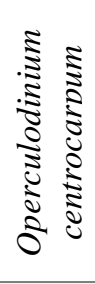 & 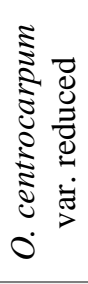 & 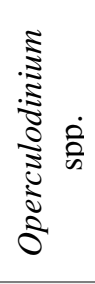 & 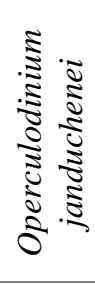 & 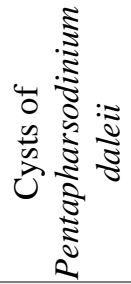 \\
\hline $2018-1$ & 304 & 16 & 3 & 2 & 49 & 288 & 3 & 0 & 0 & 0 & 0 & 1 & 0 & 1 & 30 & 3 & 0 & 0 & 0 \\
\hline $2018-2$ & 301 & 12 & 17 & 6 & 22 & 287 & 0 & 0 & 0 & 0 & 0 & 1 & 0 & 2 & 9 & 2 & 0 & 0 & 4 \\
\hline $2018-3$ & 304 & 15 & 3 & 2 & 9 & 314 & 2 & 0 & 0 & 0 & 0 & 0 & 0 & 1 & 2 & 0 & 0 & 0 & 0 \\
\hline $2018-4$ & 287 & 45 & 7 & 3 & 17 & 305 & 2 & 0 & 0 & 0 & 0 & 0 & 0 & 0 & 9 & 0 & 0 & 0 & 2 \\
\hline $2018-5$ & 306 & 39 & 9 & 7 & 9 & 298 & 0 & 0 & 0 & 0 & 0 & 0 & 0 & 0 & 0 & 0 & 0 & 0 & 0 \\
\hline $2018-6$ & 193 & 36 & 9 & 3 & 23 & 373 & 9 & 0 & 0 & 1 & 0 & 2 & 0 & 1 & 1 & 0 & 0 & 0 & 1 \\
\hline $2018-7$ & 321 & 35 & 9 & 1 & 23 & 300 & 0 & 0 & 0 & 0 & 0 & 0 & 0 & 1 & 4 & 0 & 0 & 0 & 0 \\
\hline $2018-8$ & 158 & 41 & 21 & 0 & 2 & 12 & 0 & 0 & 0 & 0 & 0 & 0 & 0 & 0 & 0 & 0 & 0 & 0 & 0 \\
\hline $2018-9$ & 293 & 17 & 4 & 2 & 12 & 313 & 0 & 0 & 0 & 0 & 0 & 1 & 0 & 0 & 0 & 0 & 1 & 0 & 0 \\
\hline $2018-10$ & 274 & 53 & 12 & 6 & 35 & 319 & 8 & 0 & 0 & 0 & 0 & 2 & 0 & 0 & 2 & 0 & 0 & 0 & 0 \\
\hline $2018-11$ & 247 & 62 & 16 & 17 & 52 & 294 & 2 & 0 & 0 & 0 & 0 & 1 & 2 & 1 & 3 & 0 & 0 & 0 & 1 \\
\hline 2018-12 & 251 & 76 & 18 & 4 & 25 & 310 & 2 & 0 & 0 & 0 & 0 & 0 & 1 & 0 & 1 & 0 & 1 & 0 & 0 \\
\hline $2018-13$ & 250 & 61 & 5 & 6 & 35 & 275 & 0 & 1 & 0 & 1 & 0 & 1 & 1 & 0 & 1 & 0 & 0 & 0 & 0 \\
\hline 2018-14 & 215 & 94 & 12 & 6 & 26 & 300 & 4 & 0 & 0 & 0 & 0 & 2 & 1 & 2 & 2 & 0 & 0 & 0 & 0 \\
\hline 2018-15 & 92 & 39 & 7 & 1 & 21 & 331 & 0 & 0 & 0 & 0 & 0 & 1 & 0 & 0 & 1 & 0 & 0 & 0 & 0 \\
\hline 2018-16 & 222 & 91 & 13 & 3 & 18 & 351 & 1 & 0 & 0 & 0 & 0 & 0 & 0 & 0 & 0 & 0 & 0 & 0 & 0 \\
\hline $2018-17$ & 255 & 53 & 1 & 2 & 44 & 302 & 0 & 0 & 0 & 0 & 0 & 0 & 1 & 0 & 0 & 0 & 0 & 0 & 0 \\
\hline 2018-18 & 233 & 86 & 3 & 4 & 38 & 318 & 1 & 0 & 0 & 2 & 0 & 0 & 0 & 2 & 0 & 0 & 0 & 0 & 1 \\
\hline $2018-19$ & 184 & 106 & 14 & 7 & 37 & 280 & 0 & 0 & 0 & 0 & 0 & 1 & 2 & 0 & 1 & 1 & 0 & 0 & 1 \\
\hline $2018-20$ & 164 & 61 & 27 & 8 & 15 & 312 & 0 & 0 & 1 & 0 & 0 & 0 & 0 & 0 & 1 & 0 & 0 & 0 & 0 \\
\hline $2018-21$ & 221 & 75 & 11 & 4 & 34 & 287 & 0 & 0 & 0 & 1 & 0 & 1 & 1 & 0 & 1 & 0 & 0 & 0 & 0 \\
\hline $2018-22$ & 202 & 102 & 4 & 3 & 41 & 267 & 0 & 0 & 2 & 2 & 0 & 2 & 0 & 0 & 3 & 1 & 0 & 0 & 0 \\
\hline $2018-23$ & 174 & 137 & 25 & 4 & 40 & 286 & 0 & 0 & 0 & 0 & 0 & 1 & 0 & 0 & 0 & 0 & 0 & 0 & 0 \\
\hline 2018-24 & 160 & 142 & 7 & 7 & 25 & 409 & 0 & 0 & 0 & 1 & 0 & 2 & 1 & 0 & 0 & 0 & 0 & 0 & 0 \\
\hline $2018-25$ & 183 & 78 & 13 & 3 & 15 & 310 & 0 & 0 & 0 & 2 & 0 & 0 & 1 & 0 & 3 & 0 & 0 & 0 & 2 \\
\hline
\end{tabular}




\begin{tabular}{|c|c|c|c|c|c|c|c|c|c|c|c|c|c|c|c|c|c|c|c|}
\hline 2018-26 & 168 & 136 & 10 & 3 & 67 & 260 & 0 & 2 & 0 & 0 & 0 & 0 & 3 & 1 & 3 & 0 & 0 & 0 & 2 \\
\hline $2018-27$ & 154 & 76 & 25 & 3 & 15 & 313 & 0 & 0 & 0 & 1 & 0 & 1 & 0 & 0 & 4 & 0 & 0 & 0 & 1 \\
\hline $2018-28$ & 78 & 44 & 34 & 8 & 12 & 263 & 0 & 1 & 1 & 0 & 0 & 0 & 0 & 0 & 1 & 0 & 0 & 0 & 0 \\
\hline 2018-29 & 131 & 81 & 22 & 1 & 15 & 306 & 2 & 0 & 0 & 0 & 0 & 1 & 0 & 0 & 4 & 0 & 0 & 0 & 0 \\
\hline 2018-30 & 228 & 87 & 12 & 2 & 23 & 353 & 0 & 0 & 0 & 1 & 0 & 1 & 0 & 0 & 4 & 0 & 0 & 0 & 0 \\
\hline 2018-31 & 179 & 55 & 9 & 1 & 20 & 321 & 0 & 1 & 0 & 1 & 1 & 0 & 0 & 1 & 2 & 0 & 0 & 0 & 1 \\
\hline 2018-32 & 247 & 55 & 6 & 2 & 26 & 310 & 0 & 2 & 0 & 1 & 0 & 2 & 2 & 1 & 1 & 0 & 0 & 0 & 1 \\
\hline 2018-33 & 161 & 32 & 8 & 3 & 19 & 304 & 0 & 1 & 0 & 2 & 0 & 3 & 3 & 0 & 2 & 0 & 0 & 0 & 0 \\
\hline 2018-34 & 275 & 32 & 8 & 4 & 34 & 282 & 0 & 2 & 1 & 1 & 0 & 0 & 1 & 3 & 6 & 1 & 1 & 0 & 0 \\
\hline 2018-35 & 246 & 17 & 3 & 0 & 38 & 277 & 1 & 0 & 0 & 1 & 0 & 1 & 0 & 0 & 11 & 0 & 0 & 0 & 1 \\
\hline 2018-36 & 285 & 22 & 5 & 4 & 24 & 303 & 0 & 2 & 0 & 0 & 0 & 1 & 1 & 1 & 8 & 0 & 0 & 0 & 2 \\
\hline 2018-37 & 324 & 10 & 0 & 4 & 51 & 258 & 0 & 0 & 0 & 0 & 0 & 0 & 3 & 3 & 10 & 2 & 1 & 0 & 1 \\
\hline 2018-38 & 303 & 12 & 4 & 3 & 25 & 295 & 1 & 0 & 0 & 0 & 0 & 2 & 0 & 1 & 4 & 0 & 0 & 0 & 0 \\
\hline 2018-39 & 372 & 1 & 3 & 1 & 57 & 275 & 0 & 1 & 0 & 0 & 0 & 0 & 2 & 2 & 2 & 0 & 0 & 0 & 1 \\
\hline $2018-40$ & 312 & 9 & 1 & 4 & 22 & 292 & 0 & 0 & 0 & 1 & 0 & 2 & 2 & 0 & 4 & 0 & 0 & 0 & 1 \\
\hline $2018-41$ & 362 & 4 & 0 & 1 & 11 & 314 & 0 & 0 & 0 & 0 & 0 & 0 & 0 & 0 & 1 & 0 & 0 & 0 & 0 \\
\hline $2018-42$ & 304 & 20 & 4 & 1 & 24 & 274 & 0 & 0 & 0 & 0 & 0 & 3 & 5 & 0 & 1 & 0 & 0 & 1 & 0 \\
\hline $2018-43$ & 363 & 9 & 2 & 1 & 25 & 299 & 0 & 0 & 0 & 0 & 0 & 1 & 2 & 0 & 12 & 2 & 0 & 0 & 1 \\
\hline 2018-44 & 304 & 1 & 3 & 11 & 41 & 277 & 0 & 0 & 0 & 0 & 0 & 0 & 1 & 1 & 15 & 3 & 0 & 0 & 2 \\
\hline 2018-45 & 312 & 17 & 4 & 4 & 27 & 297 & 0 & 0 & 0 & 0 & 0 & 0 & 0 & 0 & 14 & 2 & 0 & 0 & 0 \\
\hline $2018-46$ & 295 & 16 & 3 & 2 & 70 & 262 & 0 & 0 & 0 & 0 & 0 & 1 & 3 & 1 & 51 & 4 & 0 & 0 & 1 \\
\hline $2018-47$ & 305 & 38 & 1 & 8 & 20 & 313 & 5 & 1 & 0 & 0 & 0 & 1 & 1 & 0 & 3 & 2 & 0 & 0 & 2 \\
\hline $2018-48$ & 311 & 17 & 7 & 2 & 30 & 290 & 0 & 0 & 0 & 0 & 0 & 0 & 2 & 0 & 22 & 4 & 0 & 0 & 0 \\
\hline 2018-49 & 283 & 34 & 5 & 6 & 6 & 302 & 0 & 1 & 0 & 0 & 0 & 0 & 0 & 0 & 1 & 0 & 0 & 0 & 0 \\
\hline $2018-50$ & 328 & 11 & 3 & 4 & 8 & 312 & 0 & 0 & 0 & 0 & 0 & 1 & 0 & 1 & 1 & 1 & 0 & 0 & 0 \\
\hline $2018-51$ & 297 & 12 & 2 & 5 & 10 & 292 & 0 & 0 & 0 & 0 & 0 & 0 & 2 & 0 & 1 & 0 & 0 & 0 & 0 \\
\hline $2018-52$ & 296 & 16 & 20 & 3 & 20 & 410 & 0 & 0 & 0 & 0 & 0 & 0 & 0 & 0 & 1 & 1 & 2 & 0 & 1 \\
\hline $2018-53$ & 425 & 5 & 4 & 2 & 17 & 296 & 0 & 0 & 0 & 0 & 0 & 0 & 4 & 2 & 0 & 1 & 0 & 0 & 0 \\
\hline 2018-54 & 329 & 10 & 6 & 1 & 9 & 305 & 0 & 1 & 0 & 0 & 0 & 0 & 1 & 0 & 3 & 1 & 0 & 0 & 0 \\
\hline 2018-55 & 312 & 7 & 3 & 2 & 17 & 302 & 1 & 0 & 0 & 0 & 0 & 1 & 0 & 2 & 2 & 0 & 0 & 0 & 0 \\
\hline $2018-56$ & 300 & 9 & 0 & 8 & 26 & 471 & 0 & 0 & 0 & 0 & 0 & 1 & 1 & 0 & 8 & 0 & 0 & 0 & 0 \\
\hline $2018-57$ & 366 & 11 & 0 & 3 & 19 & 287 & 0 & 0 & 0 & 0 & 0 & 0 & 0 & 0 & 8 & 0 & 1 & 0 & 0 \\
\hline
\end{tabular}




\begin{tabular}{|c|c|c|c|c|c|c|c|c|c|c|c|c|c|c|c|c|}
\hline לֶ & 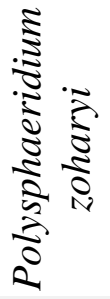 & 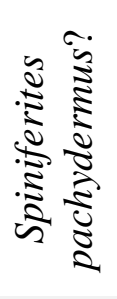 & 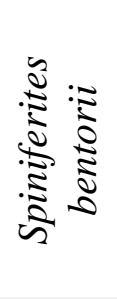 & 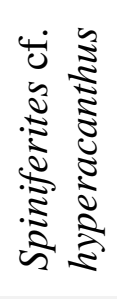 & 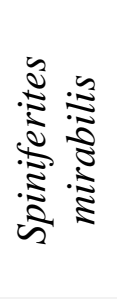 & 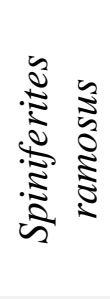 & 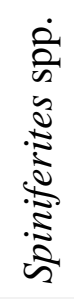 & 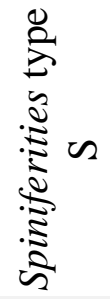 & 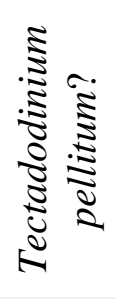 & $\begin{array}{c}0 \\
0 \\
0 \\
0 \\
0 \\
0 \\
0 \\
0 \\
0 \\
0 \\
0 \\
0 \\
2\end{array}$ & 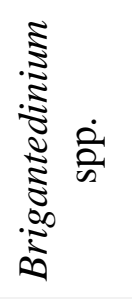 & 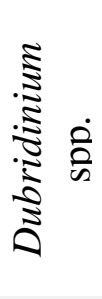 & 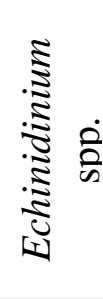 & 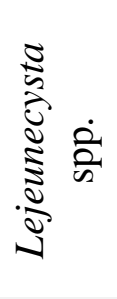 & 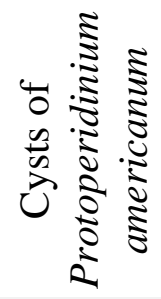 & 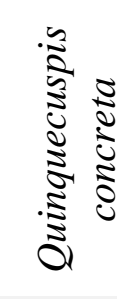 \\
\hline $2018-1$ & 0 & 0 & 0 & 0 & 0 & 1 & 10 & 0 & 0 & 25 & 198 & 26 & 0 & 7 & 2 & 16 \\
\hline $2018-2$ & 0 & 0 & 1 & 0 & 0 & 0 & 2 & 0 & 1 & 6 & 229 & 7 & 0 & 5 & 0 & 13 \\
\hline $2018-3$ & 0 & 0 & 0 & 0 & 0 & 0 & 4 & 0 & 0 & 0 & 237 & 3 & 0 & 12 & 0 & 26 \\
\hline $2018-4$ & 0 & 0 & 0 & 0 & 2 & 2 & 0 & 0 & 0 & 15 & 221 & 8 & 0 & 0 & 0 & 21 \\
\hline $2018-5$ & 0 & 0 & 0 & 0 & 0 & 0 & 9 & 0 & 0 & 8 & 262 & 2 & 2 & 0 & 0 & 6 \\
\hline $2018-6$ & 0 & 0 & 2 & 0 & 2 & 0 & 4 & 0 & 0 & 10 & 297 & 18 & 0 & 0 & 7 & 9 \\
\hline $2018-7$ & 2 & 2 & 0 & 0 & 0 & 1 & 11 & 0 & 0 & 2 & 274 & 4 & 3 & 0 & 0 & 2 \\
\hline $2018-8$ & 0 & 0 & 0 & 0 & 0 & 0 & 2 & 0 & 0 & 1 & 10 & 0 & 0 & 0 & 0 & 0 \\
\hline $2018-9$ & 0 & 0 & 1 & 0 & 4 & 1 & 4 & 0 & 0 & 5 & 262 & 12 & 0 & 0 & 0 & 10 \\
\hline $2018-10$ & 1 & 0 & 1 & 0 & 7 & 7 & 6 & 0 & 0 & 10 & 249 & 8 & 4 & 0 & 0 & 9 \\
\hline $2018-11$ & 2 & 1 & 3 & 0 & 18 & 5 & 12 & 0 & 0 & 22 & 227 & 2 & 0 & 0 & 0 & 5 \\
\hline $2018-12$ & 0 & 1 & 1 & 2 & 7 & 2 & 7 & 0 & 0 & 13 & 270 & 11 & 0 & 0 & 0 & 3 \\
\hline $2018-13$ & 0 & 0 & 2 & 3 & 12 & 1 & 9 & 0 & 0 & 8 & 246 & 3 & 0 & 0 & 0 & 4 \\
\hline $2018-14$ & 0 & 0 & 1 & 1 & 3 & 3 & 5 & 0 & 0 & 2 & 270 & 3 & 0 & 0 & 0 & 8 \\
\hline $2018-15$ & 0 & 3 & 0 & 2 & 11 & 1 & 2 & 0 & 0 & 23 & 273 & 4 & 0 & 0 & 0 & 3 \\
\hline $2018-16$ & 0 & 1 & 0 & 1 & 8 & 0 & 7 & 0 & 0 & 35 & 283 & 3 & 0 & 0 & 3 & 3 \\
\hline $2018-17$ & 0 & 0 & 1 & 0 & 29 & 3 & 10 & 0 & 0 & 3 & 263 & 9 & 0 & 0 & 1 & 4 \\
\hline $2018-18$ & 0 & 4 & 0 & 0 & 15 & 4 & 9 & 0 & 0 & 11 & 246 & 22 & 0 & 0 & 2 & 4 \\
\hline $2018-19$ & 0 & 2 & 2 & 4 & 13 & 1 & 9 & 0 & 0 & 5 & 240 & 5 & 0 & 0 & 0 & 2 \\
\hline $2018-20$ & 0 & 0 & 0 & 0 & 6 & 1 & 3 & 1 & 0 & 35 & 238 & 16 & 0 & 0 & 0 & 5 \\
\hline $2018-21$ & 0 & 1 & 1 & 0 & 15 & 2 & 10 & 1 & 0 & 1 & 261 & 4 & 0 & 0 & 0 & 5 \\
\hline $2018-22$ & 0 & 3 & 0 & 3 & 13 & 3 & 8 & 0 & 0 & 13 & 198 & 13 & 2 & 0 & 6 & 7 \\
\hline $2018-23$ & 0 & 0 & 1 & 0 & 20 & 6 & 11 & 1 & 0 & 2 & 253 & 5 & 2 & 0 & 0 & 2 \\
\hline $2018-24$ & 0 & 1 & 2 & 0 & 10 & 0 & 8 & 0 & 0 & 32 & 289 & 16 & 3 & 2 & 3 & 18 \\
\hline $2018-25$ & 0 & 0 & 0 & 0 & 4 & 2 & 0 & 0 & 0 & 16 & 197 & 31 & 0 & 1 & 6 & \\
\hline $2018-26$ & 2 & 0 & 4 & 4 & 27 & 3 & 12 & 0 & 2 & 14 & 156 & 8 & 8 & 0 & 0 & \\
\hline
\end{tabular}




\begin{tabular}{|c|c|c|c|c|c|c|c|c|c|c|c|c|c|c|c|c|}
\hline 2018-27 & 0 & 0 & 0 & 0 & 3 & 3 & 2 & 0 & 0 & 30 & 226 & 18 & 10 & 0 & 7 & 9 \\
\hline $2018-28$ & 0 & 0 & 0 & 0 & 2 & 0 & 7 & 0 & 0 & 30 & 195 & 13 & 0 & 0 & 0 & 3 \\
\hline 2018-29 & 0 & 0 & 0 & 0 & 0 & 0 & 7 & 0 & 0 & 19 & 233 & 21 & 2 & 0 & 0 & 4 \\
\hline 2018-30 & 0 & 0 & 0 & 0 & 4 & 2 & 8 & 0 & 0 & 22 & 197 & 9 & 9 & 0 & 2 & 11 \\
\hline 2018-31 & 0 & 0 & 1 & 1 & 2 & 3 & 6 & 0 & 0 & 18 & 159 & 44 & 0 & 2 & 3 & 14 \\
\hline 2018-32 & 0 & 0 & 0 & 3 & 5 & 1 & 6 & 0 & 0 & 19 & 148 & 5 & 14 & 0 & 3 & 14 \\
\hline $2018-33$ & 0 & 0 & 0 & 0 & 0 & 0 & 8 & 0 & 0 & 3 & 176 & 16 & 0 & 0 & 2 & 18 \\
\hline 2018-34 & 2 & 0 & 2 & 0 & 1 & 3 & 10 & 0 & 0 & 35 & 130 & 6 & 3 & 0 & 0 & 13 \\
\hline 2018-35 & 0 & 1 & 0 & 2 & 6 & 4 & 9 & 1 & 0 & 4 & 145 & 11 & 2 & 0 & 0 & 9 \\
\hline 2018-36 & 1 & 0 & 0 & 0 & 1 & 2 & 5 & 0 & 0 & 38 & 157 & 5 & 1 & 0 & 2 & 17 \\
\hline 2018-37 & 0 & 1 & 3 & 0 & 2 & 8 & 16 & 0 & 0 & 9 & 162 & 6 & 2 & 0 & 0 & 3 \\
\hline $2018-38$ & 0 & 1 & 1 & 0 & 2 & 3 & 9 & 1 & 0 & 16 & 230 & 7 & 2 & 0 & 0 & 10 \\
\hline 2018-39 & 0 & 0 & 4 & 0 & 0 & 12 & 32 & 0 & 0 & 7 & 225 & 2 & 1 & 0 & 0 & 5 \\
\hline $2018-40$ & 0 & 0 & 2 & 1 & 3 & 0 & 6 & 0 & 0 & 21 & 188 & 19 & 2 & 0 & 4 & 8 \\
\hline $2018-41$ & 0 & 0 & 0 & 0 & 0 & 3 & 7 & 0 & 0 & 6 & 227 & 17 & 0 & 0 & 1 & 3 \\
\hline $2018-42$ & 0 & 0 & 0 & 0 & 0 & 3 & 10 & 0 & 1 & 29 & 173 & 9 & 0 & 0 & 0 & 9 \\
\hline $2018-43$ & 0 & 0 & 0 & 0 & 1 & 1 & 4 & 0 & 1 & 28 & 207 & 24 & 0 & 0 & 5 & 9 \\
\hline $2018-44$ & 0 & 0 & 3 & 0 & 2 & 2 & 12 & 0 & 0 & 26 & 181 & 19 & 0 & 0 & 0 & 5 \\
\hline $2018-45$ & 0 & 0 & 0 & 0 & 2 & 3 & 5 & 0 & 0 & 14 & 230 & 18 & 1 & 0 & 0 & 7 \\
\hline $2018-46$ & 0 & 0 & 0 & 0 & 0 & 1 & 8 & 0 & 0 & 5 & 192 & 9 & 0 & 2 & 0 & 5 \\
\hline $2018-47$ & 0 & 0 & 1 & 0 & 0 & 1 & 3 & 0 & 0 & 8 & 241 & 22 & 1 & 0 & 0 & 6 \\
\hline $2018-48$ & 0 & 0 & 0 & 0 & 0 & 0 & 2 & 0 & 0 & 16 & 228 & 28 & 0 & 1 & 0 & 4 \\
\hline $2018-49$ & 0 & 0 & 0 & 0 & 0 & 1 & 3 & 0 & 0 & 15 & 226 & 30 & 0 & 0 & 0 & 5 \\
\hline $2018-50$ & 1 & 0 & 0 & 0 & 0 & 0 & 3 & 0 & 0 & 10 & 251 & 17 & 0 & 0 & 0 & 18 \\
\hline $2018-51$ & 0 & 1 & 0 & 0 & 0 & 1 & 5 & 0 & 0 & 7 & 246 & 5 & 0 & 1 & 0 & 6 \\
\hline $2018-52$ & 0 & 0 & 1 & 0 & 2 & 0 & 12 & 0 & 0 & 29 & 266 & 16 & 3 & 16 & 0 & 30 \\
\hline $2018-53$ & 0 & 1 & 0 & 0 & 1 & 0 & 6 & 0 & 0 & 8 & 246 & 3 & 0 & 0 & 0 & 1 \\
\hline $2018-54$ & 0 & 1 & 0 & 0 & 0 & 0 & 2 & 0 & 0 & 9 & 272 & 15 & 0 & 0 & 0 & 2 \\
\hline $2018-55$ & 1 & 0 & 0 & 0 & 0 & 0 & 10 & 0 & 0 & 9 & 256 & 18 & 0 & 0 & 0 & 7 \\
\hline $2018-56$ & 0 & 0 & 1 & 0 & 0 & 1 & 14 & 0 & 0 & 29 & 367 & 9 & 1 & 0 & 0 & 15 \\
\hline 2018-57 & 0 & 1 & 0 & 0 & 0 & 0 & 9 & 0 & 0 & 5 & 252 & 3 & 0 & 0 & 0 & 2 \\
\hline
\end{tabular}




\begin{tabular}{|c|c|c|c|c|c|c|c|c|c|}
\hline 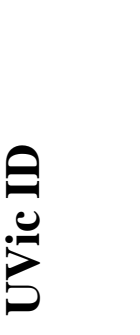 & 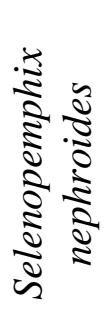 & 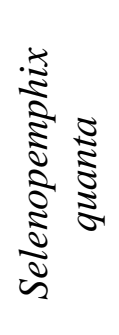 & 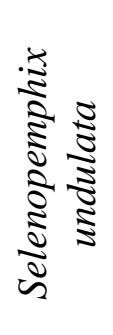 & 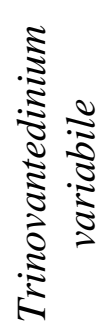 & 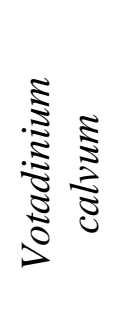 & 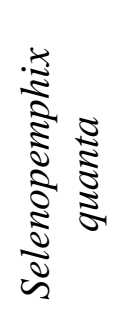 & 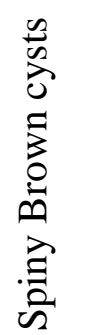 & 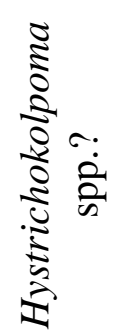 & 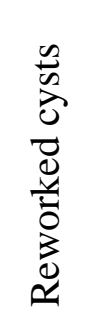 \\
\hline $2018-1$ & 1 & 3 & 8 & 0 & 0 & 3 & 2 & 2 & 2 \\
\hline $2018-2$ & 0 & 9 & 10 & 0 & 0 & 9 & 7 & 0 & 0 \\
\hline $2018-3$ & 8 & 19 & 9 & 0 & 0 & 19 & 0 & 0 & 1 \\
\hline $2018-4$ & 4 & 16 & 16 & 4 & 0 & 16 & 0 & 0 & 0 \\
\hline $2018-5$ & 2 & 8 & 8 & 0 & 0 & 8 & 2 & 0 & 1 \\
\hline $2018-6$ & 10 & 5 & 6 & 2 & 0 & 5 & 9 & 0 & 1 \\
\hline $2018-7$ & 0 & 12 & 3 & 0 & 0 & 12 & 3 & 0 & 0 \\
\hline $2018-8$ & 0 & 0 & 1 & 0 & 0 & 0 & 0 & 0 & 0 \\
\hline $2018-9$ & 4 & 18 & 2 & 0 & 0 & 18 & 0 & 0 & 0 \\
\hline 2018-10 & 5 & 24 & 5 & 0 & 0 & 24 & 4 & 0 & 0 \\
\hline $2018-11$ & 10 & 22 & 4 & 1 & 1 & 22 & 0 & 0 & 0 \\
\hline $2018-12$ & 3 & 5 & 2 & 3 & 0 & 5 & 0 & 1 & 0 \\
\hline $2018-13$ & 3 & 9 & 0 & 2 & 0 & 9 & 0 & 0 & 1 \\
\hline $2018-14$ & 2 & 14 & 0 & 1 & 0 & 14 & 0 & 0 & 2 \\
\hline $2018-15$ & 6 & 12 & 0 & 2 & 3 & 12 & 5 & 0 & 0 \\
\hline $2018-16$ & 6 & 8 & 0 & 5 & 0 & 8 & 5 & 0 & 0 \\
\hline $2018-17$ & 0 & 17 & 0 & 5 & 0 & 17 & 0 & 0 & 0 \\
\hline 2018-18 & 3 & 13 & 1 & 2 & 0 & 13 & 14 & 0 & 0 \\
\hline 2018-19 & 1 & 24 & 0 & 3 & 0 & 24 & 0 & 1 & 1 \\
\hline $2018-20$ & 3 & 5 & 0 & 0 & 0 & 5 & 8 & 1 & 0 \\
\hline $2018-21$ & 2 & 12 & 0 & 2 & 0 & 12 & 0 & 0 & 2 \\
\hline 2018-22 & 7 & 10 & 2 & 1 & 0 & 10 & 10 & 2 & 0 \\
\hline $2018-23$ & 3 & 16 & 1 & 2 & 0 & 16 & 2 & 0 & 0 \\
\hline $2018-24$ & 9 & 8 & 6 & 4 & 5 & 8 & 17 & 0 & 0 \\
\hline $2018-25$ & 3 & 29 & 0 & 0 & 0 & 29 & 21 & 0 & 1 \\
\hline $2018-26$ & 3 & 43 & 1 & 0 & 0 & 43 & 28 & 1 & 1 \\
\hline $2018-27$ & 0 & 12 & 1 & 0 & 0 & 12 & 10 & 1 & 1 \\
\hline $2018-28$ & 2 & 5 & 0 & 0 & 0 & 5 & 8 & 0 & 0 \\
\hline 2018-29 & 5 & 9 & 0 & 0 & 0 & 9 & 14 & 0 & 0 \\
\hline 2018-30 & 5 & 87 & 0 & 4 & 0 & 87 & 16 & 2 & 2 \\
\hline 2018-31 & 6 & 58 & 1 & 1 & 0 & 58 & 13 & 0 & 2 \\
\hline 2018-32 & 9 & 80 & 0 & 5 & 3 & 80 & 22 & 3 & 2 \\
\hline 2018-33 & 5 & 78 & 1 & 2 & 3 & 78 & 0 & 1 & 1 \\
\hline $2018-34$ & 2 & 77 & 0 & 4 & 5 & 77 & 10 & 2 & 2 \\
\hline $2018-35$ & 4 & 55 & 0 & 2 & 0 & 55 & 46 & 2 & 1 \\
\hline $2018-36$ & 11 & 52 & 7 & 2 & 3 & 52 & 6 & 1 & 3 \\
\hline $2018-37$ & 1 & 57 & 3 & 13 & 0 & 57 & 4 & 2 & 6 \\
\hline $2018-38$ & 5 & 12 & 1 & 4 & 2 & 12 & 8 & 0 & 2 \\
\hline
\end{tabular}




\begin{tabular}{c|ccccccccc}
$2018-39$ & 1 & 29 & 2 & 3 & 0 & 29 & 1 & 0 & 9 \\
$2018-40$ & 5 & 27 & 0 & 10 & 2 & 27 & 2 & 0 & 1 \\
$2018-41$ & 5 & 50 & 0 & 2 & 2 & 50 & 1 & 2 & 0 \\
$2018-42$ & 1 & 33 & 1 & 7 & 3 & 33 & 7 & 0 & 3 \\
$2018-43$ & 0 & 12 & 11 & 2 & 0 & 12 & 0 & 1 & 2 \\
$2018-44$ & 0 & 5 & 33 & 1 & 0 & 5 & 7 & 0 & 3 \\
$2018-45$ & 2 & 4 & 12 & 5 & 0 & 4 & 1 & 0 & 4 \\
$2018-46$ & 2 & 15 & 19 & 3 & 4 & 15 & 4 & 2 & 1 \\
$2018-47$ & 0 & 15 & 18 & 0 & 0 & 15 & 3 & 0 & 3 \\
$2018-48$ & 0 & 2 & 11 & 0 & 0 & 2 & 0 & 0 & 0 \\
$2018-49$ & 0 & 5 & 18 & 0 & 2 & 5 & 1 & 1 & 2 \\
$2018-50$ & 4 & 1 & 11 & 0 & 0 & 1 & 0 & 0 & 3 \\
$2018-51$ & 0 & 14 & 13 & 0 & 0 & 14 & 0 & 0 & 3 \\
$2018-52$ & 6 & 3 & 41 & 0 & 0 & 3 & 3 & 0 & 0 \\
$2018-53$ & 1 & 7 & 29 & 0 & 0 & 7 & 0 & 4 & 1 \\
$2018-54$ & 0 & 2 & 5 & 0 & 0 & 2 & 0 & 0 & 1 \\
$2018-55$ & 4 & 1 & 5 & 0 & 2 & 1 & 0 & 0 & 4 \\
$2018-56$ & 4 & 4 & 42 & 0 & 0 & 4 & 1 & 3 & 1 \\
$2018-57$ & 3 & 2 & 20 & 0 & 0 & 2 & 0 & 0 & 2
\end{tabular}

